\title{
Overview paper: New insights into aerosol and climate in the Arctic
}

Jonathan P. D. Abbatt ${ }^{1}$, W. Richard Leaitch ${ }^{2}$, Amir A. Aliabadi ${ }^{3}$, Allan K. Bertram ${ }^{4}$, Jean-Pierre Blanchet ${ }^{5}$, Aude Boivin-Rioux ${ }^{6}$, Heiko Bozem ${ }^{7}$, Julia Burkart ${ }^{8}$, Rachel Y. W. Chang ${ }^{9}$, Joannie Charette ${ }^{6}$, Jai P. Chaubey ${ }^{9}$, Robert J. Christensen ${ }^{1}$, Ana Cirisan ${ }^{5}$, Douglas B. Collins ${ }^{10}$, Betty Croft ${ }^{9}$, Joelle Dionne ${ }^{9}$, Greg J. Evans ${ }^{11}$, Christopher G. Fletcher ${ }^{12}$, Martí Gali ${ }^{13}$, Roya Ghahreman ${ }^{2, \mathrm{i}}$, Eric Girard ${ }^{5, \dagger}$, Wanmin Gong ${ }^{2}$, Michel Gosselin $^{6}$, Margaux Gourdal ${ }^{13}$, Sarah J. Hanna ${ }^{4}$, Hakase Hayashida ${ }^{14}$, Andreas B. Herber ${ }^{15}$, Sareh Hesaraki ${ }^{16}$, Peter Hoor ${ }^{7}$, Lin Huang ${ }^{2}$, Rachel Hussherr ${ }^{13}$, Victoria E. Irish ${ }^{4}$, Setigui A. Keita ${ }^{5}$, John K. Kodros ${ }^{17}$, Franziska Köllner ${ }^{7,18}$, Felicia Kolonjari ${ }^{2}$, Daniel Kunkel ${ }^{7}$, Luis A. Ladino ${ }^{19}$, Kathy Law ${ }^{20}$, Maurice Levasseur ${ }^{13}$, Quentin Libois ${ }^{5}$, John Liggio ${ }^{2}$, Martine Lizotte ${ }^{13}$, Katrina M. Macdonald ${ }^{11}$, Rashed Mahmood ${ }^{14,21}$, Randall V. Martin ${ }^{9}$, Ryan H. Mason ${ }^{4}$, Lisa A. Miller ${ }^{22}$, Alexander Moravek ${ }^{1}$, Eric Mortenson ${ }^{14}$, Emma L. Mungall ${ }^{1}$, Jennifer G. Murphy ${ }^{1}$, Maryam Namazi ${ }^{23}$, Ann-Lise Norman ${ }^{24}$, Norman T. O'Neill ${ }^{16}$, Jeffrey R. Pierce ${ }^{17}$, Lynn M. Russell ${ }^{25}$, Johannes Schneider ${ }^{18}$, Hannes Schulz ${ }^{15}$, Sangeeta Sharma ${ }^{2}$, Meng Si ${ }^{4}$, Ralf M. Staebler ${ }^{2}$, Nadja S. Steiner ${ }^{22}$, Jennie L. Thomas ${ }^{20,26}$, Knut von Salzen ${ }^{21}$, Jeremy J. B. Wentzell ${ }^{2}$, Megan D. Willis ${ }^{27}$, Gregory R. Wentworth ${ }^{28}$, Jun-Wei $\mathbf{X u}^{9}$, and Jacqueline D. Yakobi-Hancock ${ }^{29}$

${ }^{1}$ Department of Chemistry, University of Toronto, Toronto, Canada

${ }^{2}$ Environment and Climate Change Canada, Toronto, Canada

${ }^{3}$ School of Engineering, University of Guelph, Guelph, Canada

${ }^{4}$ Department of Chemistry,University of British Columbia, Vancouver, Canada

${ }^{5}$ Department of Earth and Atmospheric Sciences, Université du Québec à Montréal, Montréal,Canada

${ }^{6}$ Institut des sciences de la mer de Rimouski, Université duQuébec à Rimouski, Rimouski, Canada

${ }^{7}$ Institute for Atmospheric Physics,Johannes Gutenberg University, Mainz, Germany

${ }^{8}$ Aerosol Physics \& Environmental Physics, University of Vienna, Vienna, Austria

${ }^{9}$ Department of Physics and Atmospheric Science, Dalhousie University, Halifax, Canada

${ }^{10}$ Department of Chemistry, Bucknell University, Lewisburg, USA

${ }^{11}$ Department of Chemical Engineering and Applied Chemistry, University of Toronto, Toronto, Canada

${ }^{12}$ Department of Geography and Environmental Management, University of Waterloo, Waterloo, Canada

${ }^{13}$ Department of Biology,Université Laval, Québec City, Canada

${ }^{14}$ School of Earth and Ocean Sciences, University of Victoria, Victoria, Canada

${ }^{15}$ Alfred Wegener Institute, Helmholtz Centre for Polar and Marine Research, Bremerhaven, Germany

${ }^{16}$ Centre d'Applications et de Recherches en Télédétection, Université de Sherbrooke, Sherbrooke, Canada

${ }^{17}$ Department of Atmospheric Science, Colorado State University, Fort Collins, USA

${ }^{18}$ Particle Chemistry Department, Max Planck Institute for Chemistry, Mainz, Germany

${ }^{19}$ Centro de Ciencias de la Atmósfera, Universidad Nacional Autónoma de México,

Ciudad Universitaria, México City, Mexico

${ }^{20}$ ATMOS/IPSL, Sorbonne Université, UVSQ, CNRS, Paris, France

${ }^{21}$ Canadian Centre for Climate Modelling and Analysis, Environment and Climate Change Canada, Victoria, Canada

${ }^{22}$ Institute of Ocean Sciences, Fisheries and Oceans Canada, Sidney, Canada

${ }^{23}$ Department of Mathematics, University of Isfahan, Isfahan, Iran

${ }^{24}$ Department of Physics and Astronomy, University of Calgary, Calgary, Canada

${ }^{25}$ Scripps Institution of Oceanography, University of California, San Diego, La Jolla, USA

${ }^{26}$ Université de Grenoble Alpes, CNRS, IRD, IGE, Grenoble, France

${ }^{27}$ Lawrence Berkeley National Laboratory, Berkeley, USA

${ }^{28}$ Alberta Environment and Parks, Edmonton, Canada

${ }^{29}$ National Research Council, Ottawa, Canada

${ }^{\mathrm{i}}$ previously published under the name Roghayeh Ghahremaninezhad 
$\dagger$ deceased

Correspondence: Jonathan P. D. Abbatt (jonathan.abbatt@utoronto.ca) and W. Richard Leaitch (leaitchs@gmail.com)

Received: 19 September 2018 - Discussion started: 12 October 2018

Revised: 1 February 2019 - Accepted: 11 February 2019 - Published:

Abstract. Motivated by the need to predict how the Arctic atmosphere will change in a warming world, this article summarizes recent advances made by the research consortium NETCARE (Network on Climate and Aerosols: Addressing Key Uncertainties in Remote Canadian Environments) that contribute to our fundamental understanding of Arctic aerosol particles as they relate to climate forcing. The overall goal of NETCARE research has been to use an interdisciplinary approach encompassing extensive field observations and a range of chemical transport, earth system, and biogeochemical models. Several major findings and advances have emerged from NETCARE since its formation in 2013. (1) Unexpectedly high summertime dimethyl sulfide (DMS) levels were identified in ocean water (up to $75 \mathrm{nM}$ ) and the overlying atmosphere (up to $1 \mathrm{ppbv}$ ) in the Canadian Arctic Archipelago (CAA). Furthermore, melt ponds, which are widely prevalent, were identified as an important DMS source (with DMS concentrations of up to $6 \mathrm{nM}$ and a potential contribution to atmospheric DMS of $20 \%$ in the study area). (2) Evidence of widespread particle nucleation and growth in the marine boundary layer was found in the CAA in the summertime, with these events observed on $41 \%$ of days in a 2016 cruise. As well, at Alert, Nunavut, particles that are newly formed and grown under conditions of minimal anthropogenic influence during the months of July and August are estimated to contribute $20 \%$ to $80 \%$ of the 30 $50 \mathrm{~nm}$ particle number density. DMS-oxidation-driven nucleation is facilitated by the presence of atmospheric ammonia arising from seabird-colony emissions, and potentially also from coastal regions, tundra, and biomass burning. Via accumulation of secondary organic aerosol (SOA), a significant fraction of the new particles grow to sizes that are active in cloud droplet formation. Although the gaseous precursors to Arctic marine SOA remain poorly defined, the measured levels of common continental SOA precursors (isoprene and monoterpenes) were low, whereas elevated mixing ratios of oxygenated volatile organic compounds (OVOCs) were inferred to arise via processes involving the sea surface microlayer. (3) The variability in the vertical distribution of black carbon (BC) under both springtime Arctic haze and more pristine summertime aerosol conditions was observed. Measured particle size distributions and mixing states were used to constrain, for the first time, calculations of aerosol-climate interactions under Arctic conditions. Aircraft- and groundbased measurements were used to better establish the BC source regions that supply the Arctic via long-range trans- port mechanisms, with evidence for a dominant springtime contribution from eastern and southern Asia to the middle troposphere, and a major contribution from northern Asia to the surface. (4) Measurements of ice nucleating particles (INPs) in the Arctic indicate that a major source of these particles is mineral dust, likely derived from local sources in the summer and long-range transport in the spring. In addition, INPs are abundant in the sea surface microlayer in the Arctic, and possibly play a role in ice nucleation in the atmosphere when mineral dust concentrations are low. (5) Amongst multiple aerosol components, BC was observed to have the smallest effective deposition velocities to high Arctic snow $\left(0.03 \mathrm{~cm} \mathrm{~s}^{-1}\right)$.

\section{Introduction}

Rapid changes in the Arctic environment including rising temperatures, melting sea ice, elongated warm seasons, and changing aerosol and trace gas long-range transport patterns (IPCC, 2013) are driving a growing interest in developing a better understanding of the processes that control Arctic climate. Furthermore, because high-latitude climate change is a bellwether for change on a global scale, it is particularly important to understand the feedbacks that lead to amplification of Arctic warming (Serreze and Barry, 2011).

This article discusses key discoveries that have been made in climate-related Arctic aerosol research by the NETCARE (Network on Climate and Aerosols: Addressing Key Uncertainties in Remote Canadian Environments) research network. Formed in 2013, NETCARE consists of Canadian academic and government researchers along with international collaborators. Given the highly diverse nature of interrelated earth system processes that couple within the Arctic environment, the network is necessarily interdisciplinary, consisting of climate and air quality modellers, atmospheric chemists, aerosol and cloud physicists, biological and chemical oceanographers, biogeochemists, and remote sensing experts. Over the past 6 years, the network has conducted a set of field campaigns and modelling projects focused on the sources and loss mechanisms of atmospheric particles, their chemical and optical characteristics, and their role in climate. The field studies were conducted using a variety of platforms including the Alfred Wegener Institute's Polar 6 aircraft (Herber et al., 2008), the research icebreaker Canadian Coast Guard Ship (CCGS) Amundsen, and the Dr. Neil Triv- 
Table 1. NETCARE Arctic field campaigns.

\begin{tabular}{lll}
\hline Date & Location(s) & Platform \\
\hline $\begin{array}{l}\text { 2014 (July-August) } \\
2014 \text { (July) }\end{array}$ & $\begin{array}{l}\text { Canadian Arctic Archipelago } \\
\text { Resolute Bay, Nunavut }\end{array}$ & $\begin{array}{l}\text { ship - CCGS Amundsen } \\
\text { airborne - Polar 6 } \\
\text { ground - Dr. Neil Trivett Global }\end{array}$ \\
& Alert, Nunavut & $\begin{array}{l}\text { Atmosphere Watch Observatory } \\
\text { airborne - Polar 6 }\end{array}$ \\
2015 (April) & Longyearbyen, Alert, Eureka, Inuvik & $\begin{array}{l}\text { aily-August) } \\
\text { ship - CCGS Amundsen } \\
\text { ground - Dr. Neil Trivett Global }\end{array}$ \\
& Canadian Arctic Archipelago & Atmosphere Watch Observatory \\
\hline
\end{tabular}

ett Global Atmosphere Watch Observatory at Alert, Nunavut (hereafter, Alert). Table 1 and Fig. 1 present the locations and dates of the field studies. The modelling studies used the Canadian Atmospheric Global Climate Model (CanAM; von Salzen et al., 2013), the GEOS-Chem chemical transport model with associated microphysics module TOMAS (Croft et al., 2016b), Environment and Climate Change Canada's GEM-MACH chemical transport model (Moran et al., 2010), coupled ice-ocean biogeochemistry models in 1-D and 3D configurations (Hayashida et al., 2018; Mortenson et al., 2018), and the Lagrangian particle dispersion model FLEXPART (Stohl et al., 2005). The overall goals of the network have been to study the nature of fundamental biogeochemical and physical processes that connect aerosol to climate in environments that vary from pristine to polluted, such as those found in the Arctic, in order to use this new understanding to improve the accuracy of the different modelling approaches used to simulate climate in these environments.

The network's output is documented through a special issue across three journals: Atmospheric Chemistry and Physics; Biogeosciences; and Atmospheric Measurement Techniques (https://www.atmos-chem-phys.net/ special_issue835.html; Bopp et al., 2014), of which this article is a part. NETCARE has also produced a number of publications in other journals. All of the NETCARE atmospheric measurements are in a publicly available archive at https://open.canada.ca (last access: 16 February 2019). The specific goal of this overview paper is to synthesize the results from NETCARE and to act as a gateway into the more detailed results described within the special issue and elsewhere.

Written for a scientist interested in the fields of Arctic climate, atmospheric chemistry, and biogeochemistry, this article starts with a background on Arctic aerosol that is not focused on NETCARE results (Sect. 2). For additional background information, the reader is referred to Quinn et al. (2006, 2008), Law and Stohl (2007), and Willis et al. (2018). The article then presents new insights into the three topics around which NETCARE was structured: marine processes and the Arctic atmosphere (Sect. 3); the sources, sinks, and properties of Arctic aerosol (Sect. 4); and ice

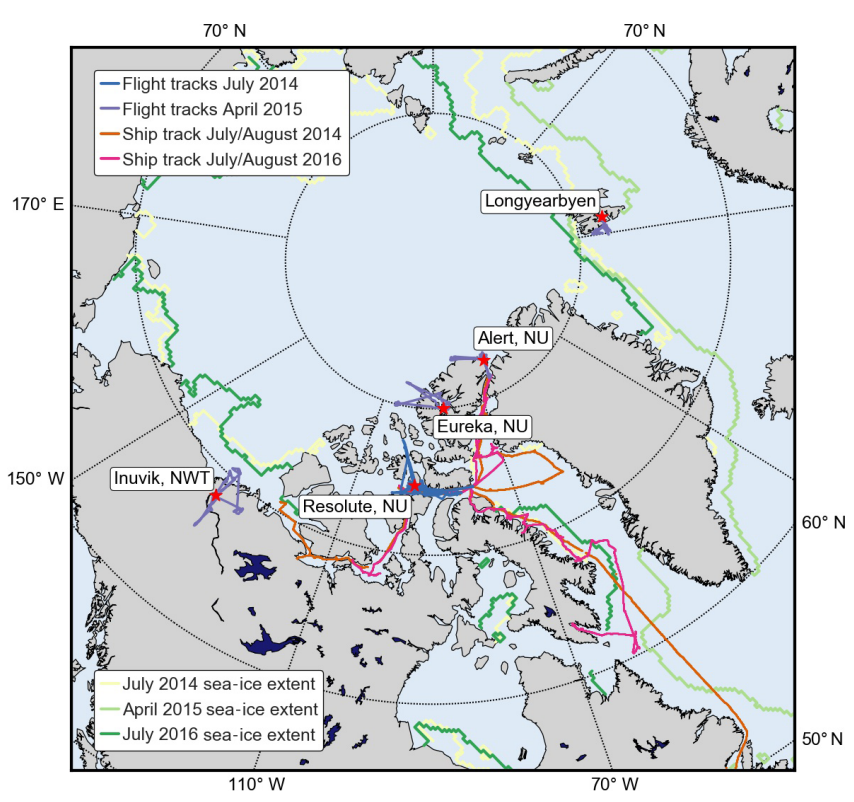

Figure 1. Map of the Arctic indicating NETCARE field work locations, including the ground station (Alert), CCGS Amundsen ship tracks in the summers of 2014 and 2016, and Polar 6 aircraft flights in summer 2014 (based out of Resolute Bay) and in spring 2015 (based out of Longyearbyen, Alert, Eureka, and Inuvik).

nucleating particles (INPs; Sect. 5). Each of these sections stands alone, so that the interested reader can focus their attention on a specific subject. However, there are clear connections between the different topics. For example, Sect. 3 (Marine processes and the summertime Arctic atmosphere) is motivated by the increasing marine impact that is arising as sea ice melts and focuses on new NETCARE Arctic measurements of dimethyl sulfide (DMS), ammonia, and oxygenated volatile organic carbon species. The oceans are an important source of such reactive gases to the atmosphere, leading to direct impacts on aerosol particles and ultimately on climate. Those connections are made in Sect. 4 (Arctic aerosol: sources, sinks, and properties), which presents insights gleaned for the summertime environment, when these marine emissions can lead to new particle formation and growth, and discusses the impacts of this aerosol on clouds. 
Section 4 also presents results from the Arctic haze springtime period, where the emphasis is on the sources of particles, their optical properties, and the potential for direct radiative forcing. Section 5 (Ice nucleating particles) addresses the select fraction of atmospheric particles that nucleate ice crystals. Section 6 concludes the article by discussing remaining research uncertainties and future priorities.

\section{Background on Arctic aerosol}

Over the last half century, our knowledge of Arctic aerosol and its role in climate has advanced from almost nothing to a clear understanding of its importance, although important questions remain regarding mechanistic details. This short section of the paper presents a comprehensive description of the field, leaving the recent NETCARE results for later sections.

Following early observations of visibility-reducing haze particles in the spring Arctic atmosphere (Greenaway, 1950), study of Arctic haze began in earnest in the 1970s (Holmgren et al., 1974; Rahn and Heidam, 1981). Investigations intensified through the 1980s, with observations (groundbased and airborne) and meteorological analyses indicating that haze particles were transported from mid-latitude pollution sources, often in layers that reached up to the tropopause, and that their concentrations increased in winter and spring due to efficient meridional transport and low rates of wet deposition (Barrie, 1986; Barrie and Hoff, 1985; Brock et al., 1989; Leaitch et al., 1989; Radke et al., 1984; Schnell and Raatz, 1984; Shaw, 1982).

Through the 1990s and beyond, concentrations of Arctic haze components declined at the northernmost observatories: Alert, Nunavut; Barrow, Alaska; Mount Zeppelin, Svalbard; and Station Nord, Greenland (Heidam et al., 1999; Hirdman et al., 2010; Quinn et al., 2009; Sharma et al., 2004, 2006; Sinha et al., 2017; Sirois and Barrie, 1999). Recent measurements (Fisher et al., 2011; Frossard et al., 2011; Leaitch et al., 2018; Massling et al., 2015; Sharma et al., 2017; Sinha et al., 2017) have found surface mass concentrations of sulfate, organic material and black carbon (BC) 3-10 times lower than those estimated from studies conducted prior to 1981 (Rahn and Heidam, 1981), but the total Arctic column burden of BC may have increased (Koch and Hansen, 2005; Sharma et al., 2013) with implications for climate forcing efficiency (Breider et al., 2017). The turn of the century saw renewed interest in Arctic haze with concern for the role of $\mathrm{BC}$ in Arctic warming (Flanner et al., 2007; Hansen and Nazarenko, 2004; Law and Stohl, 2007; McConnell et al., 2007; Quinn et al., 2008; Shindell and Faluvegi, 2009).

From the early studies of Arctic haze arose the concept of the Arctic atmosphere as a dome of cold air that regulates transport of polluted air from southerly latitudes (Barrie, 1986). The polar front extends in the winter to include more southerly industrial emissions that can be transported

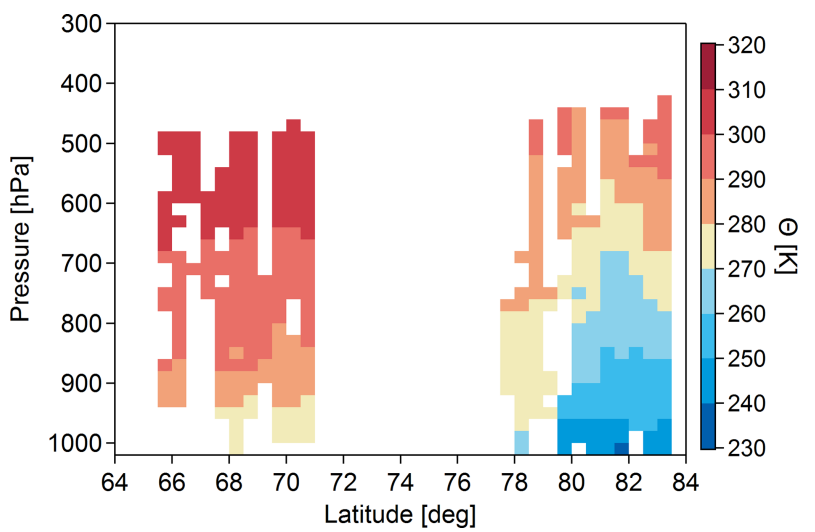

Figure 2. The potential temperature $(\Theta)$ distribution binned in steps of $1^{\circ}$ latitude and $20 \mathrm{hPa}$ pressure. $\Theta$ was calculated from the temperature and pressure measurements on board the Polar 6 aircraft during the NETCARE 2015 springtime campaign. Minimum potential temperatures of less than $270 \mathrm{~K}$ were only observed in the high Arctic lower troposphere, representing very cold air masses that isolate this area from mid-latitudinal influence. The polar dome is formed by the sloping isentropes which can be identified from the NETCARE measurements. Figure from Bozem et al. (2019).

into the high Arctic, and the front retreats in the summer to inhibit transport from mid-latitude sources. Figure 2 shows an example of identification of the polar dome in spring 2015 through measurements conducted during the NETCARE aircraft campaign. Pollution transport into the Arctic may also be influenced by the North Atlantic Oscillation (Duncan and Bey, 2004; Eckhardt et al., 2003). Arctic haze originates from Eurasia, Siberia, southeast Asia and North America, with Eurasia as the dominant source region at lower altitudes and contributions from south and central Asian sources dominating at higher altitudes (Fisher et al., 2011; Qi et al., 2017; Sharma et al., 2013; Stohl, 2006). Sea salt contributes to the haze due to the combination of stronger winds and reduced wet deposition in the winter and spring (Huang and Jaeglé, 2017; Leaitch et al., 2018) and frost flowers may contribute some marine salt (Shaw et al., 2010). Snowpack exchange is a potential springtime source of organic precursors (McNeill et al., 2012), while stratospheric contributions appear to be small (Leaitch and Isaac, 1991; Stohl, 2006).

Arctic haze warms the Arctic in several ways. BC from anthropogenic sources and forest fires deposits to snow and ice, lowering the surface albedo (Clarke and Noone, 1985; Doherty et al., 2010; Flanner et al., 2007; Forsström et al., 2013; Hegg and Baker, 2009; Keegan et al., 2014; McConnell et al., 2007). Atmospheric haze layers containing $B C$ are warmed while the underlying surface is cooled, which acts to increase atmospheric stability (Blanchet and List, 1983; Brock et al., 2011; Koch and Del Genio, 2010; Leighton, 1983; Pueschel and Kinne, 1995; Valero et al., 1984). Meridional temperature gradients are enhanced by BC outside the Arctic, which warms the air during transport to the Arctic, hence increasing 
heat transport into the Arctic (Sand et al., 2013). Dust, when present in layers over high-albedo surfaces and/or deposited to the snow, will warm the atmosphere (Bond et al., 2013; Dumont et al., 2014; Lohmann and Feichter, 2005). Arctic haze can also increase longwave radiative forcing by forming thin Arctic low-level liquid clouds (Garrett et al., 2009; Garrett and Zhao, 2006; Lubin and Vogelmann, 2006; Mauritsen et al., 2011).

However, many components of Arctic haze (e.g. sulfate; organic matter, OM; sea salt) help to cool the Arctic by scattering light back to space (Schmeisser et al., 2018) and by modifying the microphysics of liquid clouds to enhance shortwave cooling (Garrett and Zhao, 2006; Lubin and Vogelmann, 2006; Zamora et al., 2017; Zhao and Garrett, 2015). During winter and spring, sulfuric acid in Arctic haze particles may reduce their effectiveness as INPs, leading to larger crystals that precipitate more easily. As a result, there may be an increase in the dehydration rate of the atmosphere and a corresponding reduction in longwave forcing (Blanchet and Girard, 1994; Curry and Herman, 1985). At cirrus temperatures, dust, ammonium sulfate, and sea salt may also increase cloud albedo by increasing ice crystal concentrations (Abbatt et al., 2006; Sassen et al., 2003; Wagner et al., 2018).

Observed and simulated seasonal cycles of BC and sulfate typically show a maximum in near-surface concentrations in March or April (Barrie and Hoff, 1985; Eckhardt et al., 2015; Garrett et al., 2010; Sharma et al., 2006) and clean conditions in the summertime. Natural emissions of $\mathrm{BC}$ from vegetation fires are considerable in late spring to early summer in the Arctic and at mid-latitudes (Mahmood et al., 2016). Production of sulfate aerosol is more efficient in the warm than the cold seasons (Mahmood et al., 2018; Tesdal et al., 2015). The decline in Arctic haze after its peak in early spring and the approach to the summertime pristine conditions are largely related to changes in transport as the polar front moves northward and aerosol scavenging rather than a reduction in aerosol production. Wet deposition associated with transport across the retracted polar front, frequent low-intensity precipitation, and longer residence times within the polar dome keep the summertime near-surface Arctic nearly free of anthropogenic aerosol (Barrie, 1986; Stohl, 2006; Garrett et al., 2010; Browse et al., 2012). However, at higher altitudes up to $8 \mathrm{~km}$, long-range transport from mid-latitude pollution into the Arctic was also observed in summer (Schmale et al., 2011). Marine sources have a strong influence on the Arctic summer aerosol near the surface and possibly aloft (Dall'Osto et al., 2017; Korhonen et al., 2008b; Stohl, 2006).

Summer sources of sulfate appear to be the oxidation of DMS from the Arctic Ocean as well as connected waters to the south, volcanism, residual Arctic haze sulfate, and some anthropogenic sulfate or $\mathrm{SO}_{2}$ that may leak past the Arctic front into the dome (Leaitch et al., 2013). Methane sulfonic acid (MSA), another product of DMS oxidation, is most prominent in the spring and summer, and its levels are linked to the northward migration of the marginal ice zone (Laing et al., 2013; Leck and Persson, 1996; Quinn et al., 2009; Sharma et al., 2012). Aside from DMS, natural sources that can contribute to summertime Arctic atmospheric organic matter include biomass burning (Chang et al., 2011a; Stohl, 2006) and sea spray (Chang et al., 2011a; Frossard et al., 2014; Shaw et al., 2010). Sea spray encompasses marine emissions of aerosol precursors, products of photochemical processes transforming organic compounds at the ocean surface, and colloidal gels (Leck and Bigg, 1999, 2005, 2007; Orellana et al., 2011).

Characterized by a unimodal diameter distribution centred between 200 and $300 \mathrm{~nm}$ (Bigg, 1980; Heintzenberg, 1980; Leaitch and Isaac, 1991; Radke et al., 1984; Staebler et al., 1994), Arctic haze particles are effective at both scattering light (Andrews et al., 2011; Schmeisser et al., 2018) and acting as nuclei for cloud droplets (Earle et al., 2011; Komppula et al., 2005). In contrast, the summertime number distribution is dominated by smaller Aitken particles resulting from newly formed particles that have experienced modest growth in the near-pristine summer Arctic. Their small sizes render Aitken particles relatively ineffective at scattering light, but they may be able to influence cloud microphysics in the clean summertime Arctic (Korhonen et al., 2008b).

Overall, the net effect of anthropogenic aerosols has been to cool the Arctic (Fyfe et al., 2013; Najafi et al., 2015), and Navarro et al. (2016) showed that reductions in Arctic haze have contributed to the sharp increase in the rate of Arctic warming since 1990. Mitigation of BC emissions may help to slow Arctic warming so long as cooling components are not simultaneously mitigated (Kopp and Mauzerall, 2010; Sand et al., 2013; Shindell and Faluvegi, 2009).

As seen from this brief overview, understanding natural aerosol processes in addition to anthropogenic aerosol sources is vital for climate studies, as anthropogenic aerosol forcing is measured against the natural component (Carslaw et al., 2013; Megaw and Flyger, 1973). For example, in the winter and spring, sea salt aerosol may play an important climate role (Kirpes et al., 2018). At the start of NETCARE, detailed knowledge of natural particle sources and their impacts on clouds in the nearly pristine summer was incomplete, and it became a major focus of the network's research activities.

\section{Marine processes and the summertime Arctic atmosphere}

\subsection{Rationale and research questions}

In remote marine atmospheres such as the summertime Arctic, assessing the impact of natural marine biogenic aerosol (MBA) sources on cloud formation is pivotal to accurately estimating climate forcing (Carslaw et al., 2013; Charlson et al., 1987). While a variety of organic compounds, such as marine microgels, may be relevant primary MBA sources 
in the Arctic (Leck and Bigg, 2005; Orellana et al., 2011), DMS-derived sulfate is thought to be a key precursor to secondary marine aerosol mass over biologically productive regions (Ghahremaninezhad et al., 2016; Leaitch et al., 2013; McCoy et al., 2015; Park et al., 2017). The production of DMS and other organic compounds in polar regions is linked to the productivity of microalgae, as well as to the dynamics and the structure of pelagic (oceanic) and sympagic (iceassociated) microbial food webs (Gabric et al., 2017; Levasseur, 2013; Simó, 2001; Stefels et al., 2007). Peaks in the DMS proxy MSA have been observed in association with bursts of phytoplankton productivity in the high Arctic (Becagli et al., 2016). As well, atmospheric DMS mixing ratios in the marine boundary layer have been shown to transiently peak during the phytoplankton growth period from May to September (Park et al., 2013, 2018). Particle nucleation and growth events have been observed even at moderate levels of atmospheric and oceanic DMS in the high Canadian Arctic (Chang et al., 2011b; Rempillo et al., 2011).

Despite these compelling indications of the key role played by marine biogenic DMS in contributing to sulfate aerosols (Rempillo et al., 2011), measurements of seawater and sea-ice DMS during the biologically productive summer months (June to August) that coincide with clean aerosol time periods are still scarce (Jarníková et al., 2018; Levasseur, 2013). The paucity of DMS measurements in iceassociated habitats, such as under the sea ice, in melt ponds atop the ice, or directly at the Arctic sea-ice margin, is even greater (Levasseur, 2013). Sea ice not only acts to modulate gaseous exchange but also hosts active microorganisms (Gradinger, 2009), making it a fundamental driver of various MBA precursors, including DMS (Arrigo, 2014; Gabric et al., 2017; Korhonen et al., 2008b). Our understanding of the processes that control other key gases that can lead to aerosol formation in marine environments, including ammonia and volatile organic compounds (VOCs), is particularly weak. There have been very few measurements of their Arctic abundance in the past and we have a poor understanding of their sources. In this context, NETCARE targeted the spatio-temporal variability in DMS and the underlying ecosystemic mechanisms controlling its abundance in the eastern Canadian Arctic (Canadian Arctic Archipelago, henceforth CAA, and northern Baffin Bay), along with the atmospheric abundances and sources of other key gases.

\subsection{DMS production in oceanic and ice-associated environments}

The two NETCARE summer campaigns (July-August 2014 and 2016; see Fig. 1 and Table 1) revealed high openwater concentrations of DMS (interquartile range of 5.1$10.9 \mathrm{nmol} \mathrm{L}^{-1}$, maximum $\left.75 \mathrm{nmol} \mathrm{L}^{-1}\right)$ in the eastern Canadian Arctic. Previous pan-Arctic measurements had an interquartile range of $0.9-5.9 \mathrm{nmol} \mathrm{L}^{-1}$ and a maximum of $26 \mathrm{nmol} \mathrm{L}^{-1}$. These results challenged the representativeness of measurements conducted during previous cruises in the Eastern Canadian Arctic in late summer and early fall (Luce et al., 2011; Motard-Côté et al., 2012) by showing that average summer surface DMS concentrations in this part of the Arctic were at least 2-fold higher than measurements conducted later in the season. The range of seawater DMS concentrations measured in the CAA during the NETCARE expeditions in 2014 (Fig. 3) and 2016 is comparable to those observed in the same area and season in 2015 by Jarníková et al. (2018), who found the highest DMS concentrations in association with localized peaks of chlorophyll $a$, a proxy of phytoplankton biomass. Combining oceanic and atmospheric NETCARE data sets provided further evidence that marine DMS hotspots were associated with high atmospheric DMS (Mungall et al., 2016). As described in Sect. 4, connections were also found between localized regions of high oceanic biological activity and new particle formation and growth events (Collins et al., 2017; Mungall et al., 2016) that may be partly caused by DMS and organic emissions. These new observations lend strong support to the hypothesis that local Arctic DMS sources are responsible for the summertime peaks in MSA measured at Alert (Leaitch et al., 2013; Sharma et al., 2012).

Novel measurements made during NETCARE also substantiated the potentially important role played by melt ponds. An in-depth study of nine melt ponds revealed that brackish melt ponds over first-year sea ice (FYI) may have DMS concentrations ranging from 3 to $6 \mathrm{nmol} \mathrm{L}^{-1}$ (Fig. 3) with an average of $3.7 \mathrm{nmol} \mathrm{L}^{-1}$ (Gourdal et al., 2018). These concentrations are higher than the area-weighted mean of ca. $2.4 \mathrm{nmol} \mathrm{L}^{-1}$ derived from the global climatology of Lana et al. (2011), bringing support to the suggestion that melt ponds may represent a significant source of DMS in the Arctic. A search for the underlying mechanisms associated with the presence of DMS in these melt ponds revealed that intrusions of seawater through permeable sea ice is a key physical process allowing their colonization by DMS-producing marine protists (Gourdal et al., 2018). Considering that the areal coverage of melt ponds may extend up to $90 \%$ over Arctic FYI (Rösel et al., 2012) these results shed light on a previously overlooked source of DMS to the atmosphere and further call for a re-evaluation of the emissions from these regions within climatologies that currently assume the absence of DMS fluxes above ice-covered waters (Lana et al., 2011). In a simulation exercise, melt ponds were found to contribute an average of $20 \%$ (and up to $100 \%$ ) of the atmospheric DMS over and near ice-covered regions of the Arctic during the melt season (Mungall et al., 2016).

While marginal ice zones (MIZs) and various ice-edge systems have long been recognized for their teeming biological activity (Mundy et al., 2009; Perrette et al., 2011) and potential for heightened DMS production (Galí and Simó, 2010; Levasseur, 2013; Matrai and Vernet, 1997), they remain surprisingly under-documented for their specific role in MBA production in the eastern Canadian Arctic during 


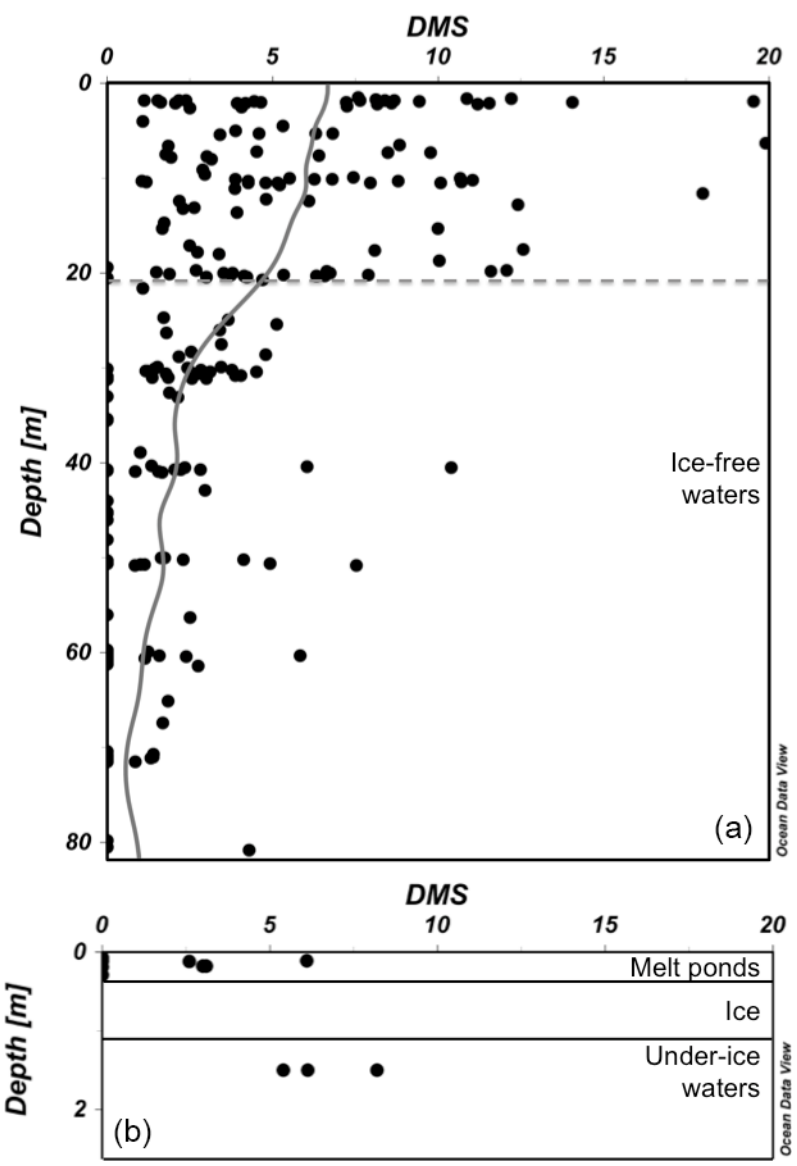

Figure 3. (a) Concentrations of DMS $\left(\mathrm{nmol} \mathrm{L}^{-1}\right)$ in ice-free waters as a function of depth $(\mathrm{m})$ with moving average line (all data, $n=208$ ). The grey dotted line represents the average surface mixed layer depth $\left(Z_{\mathrm{m}}=21 \mathrm{~m}\right)$ estimated as the depth at which the gradient in density between two successive depths was $>0.03 \mathrm{~kg} \mathrm{~m}^{3}$. (b) Concentrations of DMS $\left(\mathrm{nmol} \mathrm{L}^{-1}\right)$ in melt ponds $(n=9)$ atop first-year sea ice (Gourdal et al., 2018) and in under-ice waters $(n=3)$. All data are from the 2014 NETCARE cruise on board CCGS Amundsen.

summer. Two distinct MIZs explored during the summer of 2014 revealed highly contrasting DMS dynamics, suggesting that whether the sea ice is FYI or multi-year ice (MYI) is of paramount importance in shaping marine food webs and the net production of DMS in the water exiting the ice pack. Contrasting DMS dynamics between FYI and MYI systems were likely linked to differences in light penetration through the ice pack and its availability to primary producers in the waters just below the ice. At the MYI edge in Kennedy Channel $\left(\right.$ ca. $\left.81^{\circ} \mathrm{N}\right)$, DMS concentrations were very low at the ice edge and increased progressively over several kilometres as the water flowed away from the ice pack, suggesting that time out from under the ice was required for development of a phytoplankton bloom and the concomitant production of DMS. However, at a FYI edge in the CAA (ca. $74^{\circ} \mathrm{N}$ ), DMS concentrations were already high under the ponded sea ice
(Fig. 3) due to the presence of an under-ice bloom. Consequently, the surface waters exiting the ponded FYI displayed high DMS even at the very edge of the ice pack. The elevated levels of DMS persisted for several kilometres away from the ice edge. Thus, beyond the direct contributions melt ponds make to DMS fluxes, results from the NETCARE campaigns suggest that melt ponds play an additional role in DMS dynamics by promoting the earlier onset of under-ice phytoplankton blooms and DMS production (Lizotte et al., 2019). Taken together, these observations reveal the potential for high DMS emissions to the atmosphere immediately upon the cracking, opening, or melting of ponded FYI without the prerequisite of an ice-free period to initiate a phytoplankton bloom and potential accumulation of DMS in surface waters.

\subsection{Gaseous aerosol precursors in Arctic marine and coastal environments}

High levels of DMS have previously been associated with aerosol formation and growth in the CAA (Chang et al., 2011b; Park et al., 2017; Rempillo et al., 2011). As part of NETCARE, new atmospheric measurements of DMS were performed from both the Polar 6 aircraft and the CCGS Amundsen icebreaker. Mean DMS mixing ratios in the Arctic lower free troposphere in April 2015 were found to be unexpectedly high (average $116 \pm 8 \mathrm{ppt}$ ) relative to those from the July 2014 campaign $(20 \pm 6 \mathrm{ppt}$ ) (Ghahremaninezhad et al., 2017). The springtime levels likely reflect long-range transport from more southerly open-ocean regions. In the summertime, the boundary layer mixing ratios were at times much higher than they were in the spring in both 2014 (Mungall et al., 2016) and 2016 (unpublished results), reflecting nearby marine sources. For example, high atmospheric DMS concentrations (up to $1800 \mathrm{ppt}$, median $144 \mathrm{ppt}$ ) were found within the boundary layer from shipbased grab samples collected in July and August 2016. For a similar period and location in 2014, these values were up to 1100 ppt (median 186 ppt; Mungall et al., 2016). Evidence for atmospheric DMS was the widespread prevalence of biogenic DMS oxidation products in the marine boundary layer (Ghahremaninezhad et al., 2016).

VOCs were measured in the marine atmosphere during the 2014 CCGS Amundsen cruise. Isoprene and monoterpene levels were frequently below detection limit, but occasionally reached as high as $15 \mathrm{ppt}$ (Mungall et al., 2016). Oxygenated volatile organic compounds (OVOCs) were also measured, using an instrument that is especially sensitive to organic acids. High levels of formic acid (up to $4 \mathrm{ppb}$ ) and isocyanic acid (up to $80 \mathrm{ppt}$ ) were strongly correlated with a suite of $\mathrm{C}_{4}-\mathrm{C}_{11}$ oxo-acids (Mungall et al., 2017). Using positive matrix factorization, these OVOCs, which were elevated in regions where the ocean had high dissolved organic carbon (DOC) content, were interpreted as originating from an ocean source (Fig. 4). Production at the sea surface microlayer was invoked as an explanation, because 

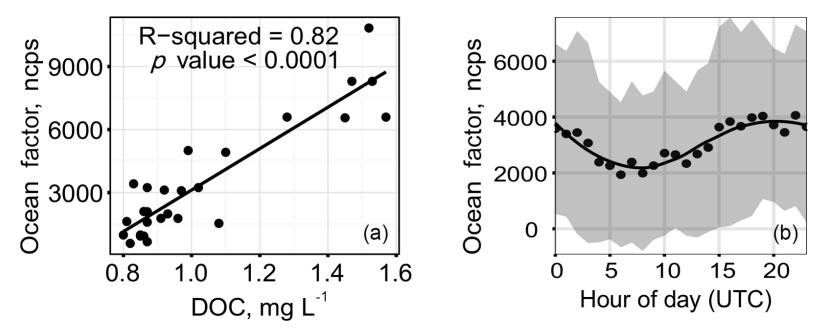

Figure 4. A large suite of oxygenated VOCs (OVOCs) were measured on the CCGS Amundsen during the 2014 cruise in the high Canadian Arctic. A factor analysis of the full time-dependent data set yielded an "Ocean factor" of small organic acids whose intensity correlated with the DOC levels in the ocean (a) and with time of day and hence downwelling radiation (b). See text for additional discussion. Figures from Mungall et al. (2017).

compounds like formic acid are sufficiently soluble that they should not escape from the bulk ocean into the atmosphere. Rather, these species must arise either through photochemistry or heterogeneous oxidation proceeding in the sea surface microlayer, or by gas-phase atmospheric oxidation of components volatilized from the microlayer. Although the OVOC molecules measured by Mungall et al. (2017) were too volatile to participate in formation of Arctic marine secondary organic aerosol (MSOA) themselves, similar processes that form larger, less volatile molecules could contribute to aerosol growth. We note that there was a weak positive correlation between total aerosol volume and the levels of OVOCs observed, indicating a potential link between the processes forming OVOCs and aerosol growth. Formation of Arctic MSOA and its role in new particle growth in the Arctic is discussed further in Sect. 4.2. (Note that in this work we use the term Arctic MSOA to refer to the organic aerosol formed in the atmosphere from marine biogenic emissions. We note that the chemical character of Arctic MSOA is not necessarily the same as that in other marine environments. For example, different biogenic precursors may be present elsewhere, and the SOA that forms from shipping emissions will have very different properties and composition.)

NETCARE provided the opportunity to make some of the first observations of ammonia in the Arctic atmosphere. Previous measurements of atmospheric ammonia over the Norwegian Sea and Arctic Ocean during the summer ranged between the detection limit (35 ppt) and 400 ppt (Johnson et al., 2008). Simultaneous measurements of sea surface ammonium $\left(\mathrm{NH}_{x}\right)$ during these previous studies ranged between 29 and $616 \mathrm{nM}$, leading to ammonia compensation points that were below the ambient concentrations, suggesting that the ocean could not act as a source of ammonia to the atmosphere. During the 2014 NETCARE campaign, hourly atmospheric ammonia measurements in the CAA marine boundary layer ranged between 40 and 870 ppt (Wentworth et al., 2016). Simultaneous measurements of $\mathrm{NH}_{x}$ at the sea surface and in melt ponds confirmed that these reservoirs could not act as sources of ammonia to the atmosphere. Boreal fires contributed to elevated atmospheric $\mathrm{NH}_{3}$ in the CAA during 2014 (Lutsch et al., 2016), but could not fully explain the spatial and temporal extent of the elevated $\mathrm{NH}_{3}$ mixing ratios. The inclusion of $\mathrm{NH}_{3}$ emissions from migratory seabird colonies in model simulations brought predicted $\mathrm{NH}_{3}$ values into much better agreement with observations (Wentworth et al., 2016) and strongly influenced modelled new particle formation (Croft et al., 2016a). In 2016, observations were again made from the CCGS Amundsen but at a higher time resolution, as well as at the Alert field site, both from mid-June to mid-July (Murphy et al., 2019). The ranges of hourly average $\mathrm{NH}_{3}$ values measured from the ship in 2016 (up to $1150 \mathrm{ppt}$; median $125 \mathrm{ppt}$ ) and at Alert (up to $720 \mathrm{ppt}$; median $234 \mathrm{ppt}$ ) were similar to the observations in 2014. Limited measurements of the tundra soil emission potential at the Alert site indicated that under the unusually high temperatures experienced at Alert in July 2016, the tundra could act as a source of ammonia to the atmosphere. Overall, the bidirectional exchange of ammonia between the atmosphere and the landocean surface is important to include in chemical transport models. The impact of ammonia on aerosol formation in the summertime Arctic, with associated climate impacts, is discussed below in Sect. 4.2.

\subsection{Connecting the ocean, sea ice and the atmosphere through DMS modelling}

Prior to the NETCARE field campaigns, the existing unextrapolated DMS climatology, averaged over the most productive time of the year (months of July and August), clearly demonstrated the scarcity of surface ocean DMS measurements in the Arctic (Lana et al., 2011). The updated Lana DMS climatology and its precursor (Kettle et al., 1999) have long represented useful tools for oceanic model validation (e.g. Le Clainche et al., 2010; Tesdal et al., 2016; Kim et al., 2017) and lack of data over the Canadian Polar shelf and the Baffin Bay area challenged the representativeness of the standard (extrapolated) version of this climatology for these specific regions (Fig. 5c). Observations gathered through NETCARE field campaigns (Fig. 5b) significantly enhanced coverage in these regions.

As part of NETCARE, a new process-based sea-iceocean biogeochemical model representing ecosystems in both the sea ice and water column of the marine Arctic was developed. The model was initially developed in a onedimensional (1-D) configuration (Mortenson et al., 2017). Subsequently, sulfur and inorganic carbon cycling were developed and implemented into the model (Hayashida et al., 2017; Mortenson et al., 2018). The simulated Arctic sea-ice ecosystem and sulfur cycle were next incorporated into a three-dimensional (3-D) regional configuration (Hayashida, 2018; Hayashida et al., 2018). This model advances previous Arctic-focused DMS model studies (Elliott et al., 2012; Jodwalis et al., 2000) in that many of the parameters concern- 


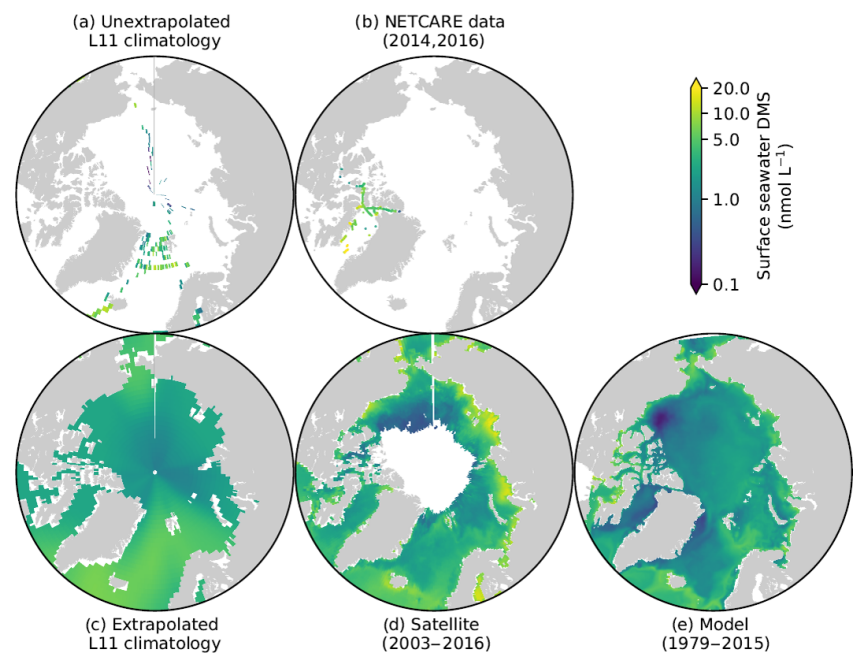

Figure 5. Pan-Arctic distribution of July-August concentrations of surface ocean DMS. Upper panels show the comparison between (a) the discrete (Lana et al., 2011) climatology and (b) the data collected during the two NETCARE field campaigns. Lower panels compare (c) the standard (Lana et al., 2011) climatology with (d) the satellite-derived (Galí et al., 2018; Hayashida, 2018) and (e) model-based (Hayashida, 2018) climatologies developed within NETCARE.

ing the DMS production are derived from recent field observations in the Arctic, enabling quantification of the relative contributions of ice algae and phytoplankton to DMS production and emissions. The 1-D simulations indicated a notable contribution of ice algae: an $18 \%$ enhancement of DMS concentrations under the ice and a $20 \%-26 \%$ enhancement of sea-air DMS fluxes during the melt period for Resolute Passage (Hayashida et al., 2017). Also in the vicinity of ice margins, simulated spikes in sea-air fluxes of DMS originating from bottom and under-ice production by algae were comparable to some of the local maxima in the summertime flux estimated for ice-free waters in the Arctic.

The data obtained during the two NETCARE ship campaigns, together with data previously available in the PMEL sea surface database (https://saga.pmel.noaa.gov/dms/, last access: 16 February 2019), were used to develop a new satellite-based model allowing the estimation of DMS at the global and regional scales (Galí et al., 2018). As can be seen in Fig. 5d, the satellite-based model provides a DMS map with an unprecedented spatial resolution (8 days, $28 \mathrm{~km} \times 28 \mathrm{~km}$ pixels). The DMS climatology based on the 3 -D process-based model simulation shows a range similar to the Lana et al. (2011) climatology, but higher spatial variability, in line with the satellite-based climatology (Fig. 5e). Together with the remote sensing approach, the numerical model is being used to help interpret the new NETCARE DMS data set, as well as to investigate longer-term and larger-scale variability, such as impacts of sea-ice reduction on DMS production (Hayashida, 2018).
Under future global warming conditions, sea-ice extent is expected to decline significantly, affecting the temporal and spatial evolution of ice algae and under-ice and open-water phytoplankton blooms. This may lead to changes in oceanic DMS emissions, although the sign and magnitude of the change is highly uncertain. Using the satellite approach mentioned above, Galí et al. (2019) showed that DMS emission has increased at a rate of about $30 \%$ decade $^{-1}$ during the last 2 decades, accompanied by large inter-annual changes linked to variable ice retreat patterns. They also estimated a 2- to 3-fold increase in DMS emission in response to complete sea-ice loss in summer.

To estimate the sensitivity of Arctic aerosols and radiative forcing to surface seawater concentrations of DMS in the Arctic, simulations with different specified surface seawater DMS concentrations and spatial distributions in the Arctic were performed for future sea-ice conditions using the Canadian Atmospheric Global Climate Model (CanAM4.3). For all of the specified surface seawater DMS conditions in the model, simulated Arctic sulfate aerosol amounts respond only weakly to a reduction in sea-ice extent owing to increases in precipitation and aerosol wet deposition associated with the receding ice and increased open water (Mahmood et al., 2018). However, nucleation rates for sulfate aerosol respond significantly to reductions in sea-ice extent, which leads to a strengthening of cloud radiative forcing in the future. Furthermore, the simulated response of the mean cloud radiative forcing in the Arctic is approximately proportional to the mean surface seawater DMS concentration in the Arctic. Thus potential future changes in sea-ice extent may result in a negative climate feedback of DMS on radiative forcing in the Arctic, as suggested by Charlson et al. (1987).

\section{Arctic aerosol: sources, sinks, and properties}

\subsection{Rationale and research questions}

The overall motivation of Arctic summertime research is to determine how the atmosphere will respond to melting sea ice, as an ocean that was largely covered by sea ice through much of the summer will potentially be ice free in summer by mid-century (AMAP, 2017; Comiso, 2011; Gregory et al., 2002; Holland et al., 2006). Given the evolution of the summertime Arctic Ocean from a bright ice cap to a dark ocean that can readily absorb solar radiation, it is of particular importance to understand factors controlling the overhead aerosol and cloud that could mediate the positive radiative feedback of declining sea ice. Precipitation associated with low clouds and fogs is common in the summertime (Browse et al., 2014). Wet deposition is a highly efficient aerosol removal mechanism, giving rise to a clean boundary layer in which new particles may be formed or into which they may be input. In these clean boundary layers, increases in the numbers of particles acting as cloud condensation nu- 
clei $(\mathrm{CCN})$ may increase longwave warming by clouds if the absolute concentrations of CCN are sufficiently low (Mauritsen et al., 2011); otherwise, increases in CCN concentrations lead to enhanced shortwave cooling. In this context, it is important to better understand the processes that give rise to new particle formation and growth to $\mathrm{CCN}$ sizes, and the associated impacts on clouds. For example, how do the emissions of biogenic gases described in Sect. 3 affect new particle formation and growth in such environments, and what is their importance relative to anthropogenic inputs from local shipping and long-range transport?

In contrast, the springtime atmosphere, with its associated Arctic haze, has been better studied than the summertime atmosphere. The results from high profile campaigns such as ISDAC (Indirect and Semi-Direct Aerosol Campaign, https: //campaign.arm.gov/isdac/, last access: 16 February 2019), ARCTAS (Arctic Research of the Composition of the Troposphere from Aircraft and Satellites, https://www.nasa.gov/ mission_pages/arctas/, last access: 16 February 2019), and ARCPAC (Aerosol, Radiation, and Cloud Processes affecting Arctic Climate, https://www.esrl.noaa.gov/csd/projects/ arcpac/, last access: 16 February 2019) have emphasized the importance of long-range transport (see also the POLARCAT project; Polar Study using Aircraft, Remote Sensing, Surface Measurements and Models, of Climate, Chemistry, Aerosols, and Transport, https://www.atmos-chem-phys.net/ special_issue182.html; Stohl et al., 2009). However, many questions remain. Taking BC-containing aerosol as an example, we can ask the following questions. What is the relative importance of sources in Europe and different Asian regions (Jiao and Flanner, 2016), and how does the relative importance of different source regions vary vertically from the surface to higher altitudes? To what degree can specific source regions be identified? How important are local sources, such as from Arctic shipping or gas flaring? How will the direct effect of light-absorbing particles be impacted by their mixing state, that is, by the degree to which they are internally or externally mixed with other components of the pollution plume? More generally, the composition of the air masses throughout the Arctic needs to be better evaluated vertically to aid in the identification of long-range transport sources, to help establish whether chemical transformations occur during transit and descent within the Arctic air mass, and to ultimately better estimate climate impacts.

Lastly, the deposition rates of aerosol constituents need to be measured to better constrain models. Ideally, both wet and dry deposition rates would be individually evaluated throughout the year, to map out the transition from a system dominated by the relatively slow loss with ice cloud scavenging versus the more efficient removal via warm clouds and fogs.

\subsection{Summertime aerosol: particle formation and growth}

As described in Sect. 2, a pronounced Aitken mode in the aerosol size distribution is a common feature during the Arctic summertime, as demonstrated by Croft et al. (2016b), who identified this feature in long-term monitoring data sets from both the Alert and Zeppelin ground stations (Fig. 6). One of the major findings from NETCARE is the widespread prevalence of 5-50 nm ultrafine particles in the summertime Canadian Arctic (Burkart et al., 2017b; Collins et al., 2017; Willis et al., 2016, 2017) and their ability to activate as CCN (Burkart et al., 2017a; Chaubey et al., 2019). While previous ship-based measurements in similar regions in late summer and fall had demonstrated new particle formation and growth events, their frequency was low. For example, in the fall period of late August to the end of September 2008, only three such events were observed over a 5-week observation period, whereas no events were observed at all in October 2007 (Chang et al., 2011b). By comparison, NETCARE measurements in mid-July to mid-August 2016 observed enhancements in $5-50 \mathrm{~nm}$ particles $41 \%$ of the time in a spatially heterogeneous manner (Collins et al., 2017). Characterization of the summertime increase in particles is provided in Fig. 7, wherein the number of particles between 15 and $30 \mathrm{~nm}$ (N15-N30) is highly enhanced at Alert in July and August, before rapidly declining in September (see the Supplement for details). As discussed in the Supplement, natural sources are estimated to contribute $20 \%-80 \%$ of the $30-50 \mathrm{~nm}$ particles during July and August. NETCARE aircraft measurements in July 2014 also demonstrated the spatial heterogeneity of $5-50 \mathrm{~nm}$ particle numbers in the inversion layer, with the highest concentrations observed over marine and cloudy regions and little detectable enhancement over ice-covered areas (Burkart et al., 2017b). These aircraft measurements also indicate that the numbers of these tiny particles in the free troposphere are spatially homogeneous and considerably lower than those measured in the inversion layer, indicative of a boundary layer source.

Significant growth of $5-50 \mathrm{~nm}$ particles to CCN sizes was clear from each observational platform. At Alert (Fig. 7), the summertime enhancement in particles between 15 and $30 \mathrm{~nm}(\mathrm{~N} 15-\mathrm{N} 30)$ coincides with the increase in particles in the 50 to $100 \mathrm{~nm}$ size range (N50-N100), which is also the size of particle activation diameters observed in the field (see Sect. 4.3). Interestingly, using Fourier Transform Infrared (FTIR) absorption of particulates collected on filters, the ratio of aerosol organic material to sulfate was also observed to increase during this time period, and the region of amide functional groups indicates a contribution of organic components from breakdown of seabird urea in guano (Leaitch et al., 2018). Likewise, a particle growth episode was clearly observed over the ice-free Lancaster Sound, in which the numbers of $5-50 \mathrm{~nm}$ particles and CCN increased in concert with the measured organic content of the PM1 aerosol 


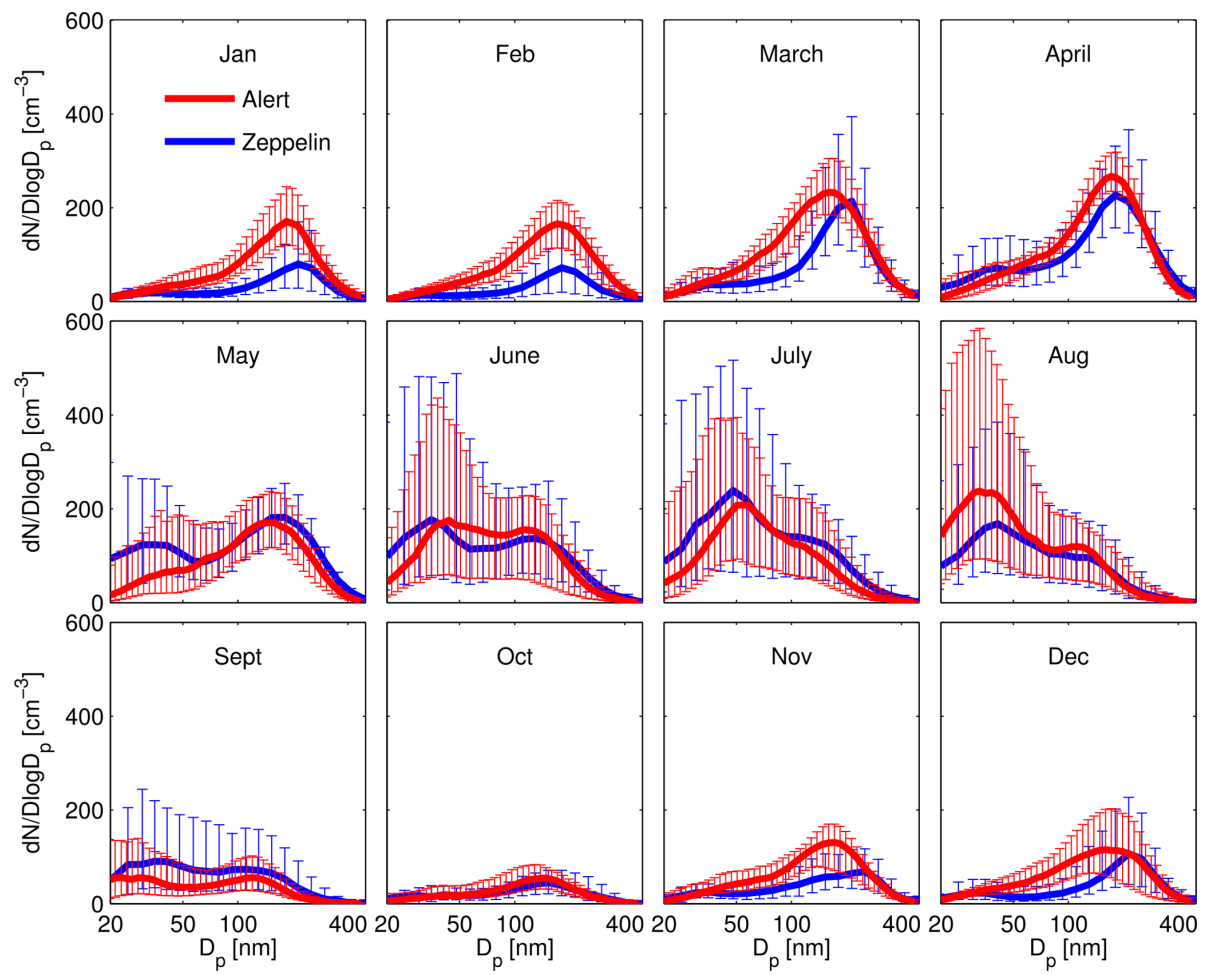

Figure 6. Aerosol size distributions from Alert and Zeppelin Arctic field stations. The pronounced accumulation mode in the winter and spring is characteristic of Arctic haze. The mode of Aitken particles is a common feature of the Arctic summertime atmosphere. Figure from Croft et al. (2016b).

(Willis et al., 2016). Across the entire aircraft campaign, the numbers of $\mathrm{CCN}$ were most strongly enhanced above background levels when the air had recently been at low altitude over open water (Fig. 8a), when the wind speeds were low, and when the organic-to-sulfate ratio of the particles was high (Willis et al., 2017). This marine influence is consistent with summertime single-particle mass spectrometric measurements of trimethylamine-containing particles in the marine boundary layer that were largely externally mixed with sea-salt-containing particles (Fig. 9; Köllner et al., 2017).

The lack of a wind speed dependence and the observations of externally mixed particulate trimethylamine suggests that secondary sources are important. Similarly, microphysical models of growing particle size distributions could only be reconciled with observations from the CCGS Amundsen icebreaker in northern Baffin Bay by invoking partitioning of semi-volatile species to the freshly nucleated and preexisting particles (Burkart et al., 2017a). This stands in contrast to mid-latitude continental settings, where the growth behaviour is best modelled by considerable condensation of low volatility species such as sulfuric acid and highly oxygenated organic molecules. We presume this semi-volatile material is organic in nature (i.e. Arctic MSOA).

Natural emissions of ammonia are also important to new particle formation and growth. Wentworth et al. (2016) used GEOS-Chem model simulations to interpret NETCARE am- monia measurements (see Sect. 3.3) and found that migratory seabird colonies (emitting $36 \mathrm{Gg} \mathrm{NH}_{3}$ between and May and September) were important sources of ammonia in the summertime Arctic. In addition, transport of boreal wildfire smoke from lower latitudes can also be an important, albeit episodic, contributor of ammonia to the summertime Arctic troposphere (Croft et al., 2016a; Lutsch et al., 2016; Wentworth et al., 2016). Croft et al. (2016a) further interpreted NETCARE observations using the GEOS-Chem-TOMAS model to find that ammonia from seabird-colony guano is a key factor contributing to the bursts of newly formed particles that are observed every summer at Alert (Fig. 10). In addition, the FTIR absorption in the region of amide functional groups indicates a contribution of organic components from the breakdown of seabird urea in guano. The chemical transport model simulations indicate that the pan-Arctic seabird-influenced particles can grow by sulfuric acid and organic vapour condensation to diameters sufficiently large to enhance pan-Arctic cloud droplet number concentrations and effects on climate in the clean Arctic summertime. Other natural ammonia sources within the same order of magnitude as the seabird-colony emissions, including but not limited to episodic biomass burning influences (Lutsch et al., 2016) and tundra emissions (Murphy et al., 2019), could also contribute to these effects (Croft et al., 2018). 


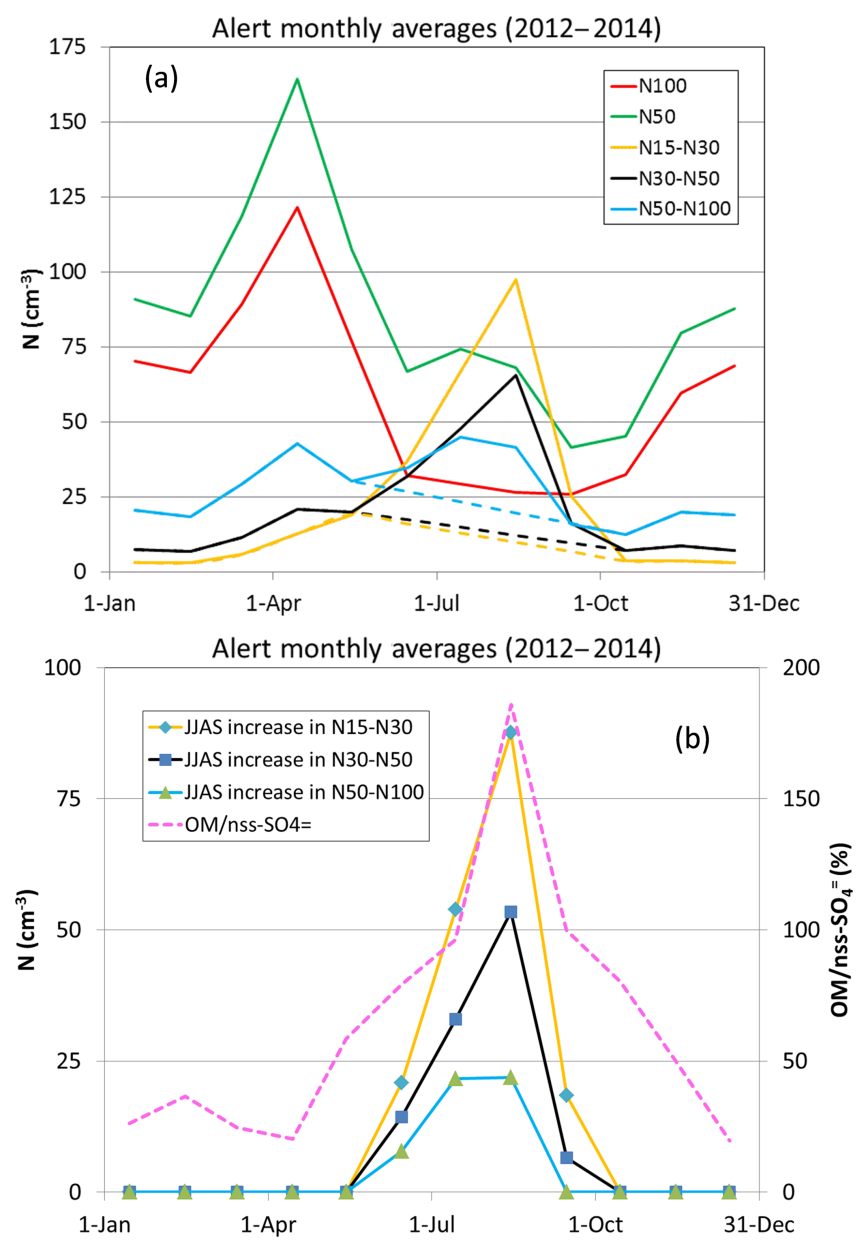

Figure 7. The changing composition and size distributions of aerosol in the high Arctic, see the Supplement for details. (a) Monthly average number concentrations for the indicated size ranges for measurements at Alert. (b) Estimated increases in particles in the indicated size intervals for June-September, inclusive, and monthly average values of $\mathrm{OM} / \mathrm{nss}^{-\mathrm{SO}_{4}^{2-}}$ (non-sea-salt sulfate) based on weekly filter samples. The data presented here are from April 2012 to October 2014, inclusive. The dashed lines in panel (a) represent an estimate of number concentrations assuming no new particle formation. The number concentration curves in panel (b) are the difference between the solid and dashed curves in panel (a).

Determining the precursors to Arctic MSOA is of crucial importance. Aerosol mass spectrometry measurements from the aircraft campaign in summer 2014 indicate that the organic chemical character of this aerosol is distinctly different from that which arises from oxidation of common continental precursors, such as isoprene or the monoterpenes (Willis et al., 2017). The mass spectral signatures indicate molecules that instead have substantial alkyl components, such as functionalized fatty acids (Fig. 8b). Long-chain fatty acids can sometimes be a significant component of the sea surface microlayer (Cunliffe et al., 2013). Croft et al. (2018) have shown that a steady flux of condensable organic ma- terial from the ocean that oxidizes with a lifetime of a day is essential for consistency between GEOS-Chem-TOMAS modelled aerosol size distributions and those measured at Alert and from the CCGS Amundsen icebreaker. This evidence strongly supports the importance of Arctic MSOA in setting the overall aerosol composition and size in the summertime.

\subsection{Summertime aerosol: impacts on liquid water clouds}

Studies at mid-latitudes have routinely shown that the smallest particles that can serve as nuclei for liquid cloud droplets are $80-120 \mathrm{~nm}$ in diameter (Hoppel et al., 1985; Leaitch et al., 1986). The smaller Aitken particles, $20-80 \mathrm{~nm}$ in size, are commonly considered to be too small to activate into cloud droplets. However, there are two circumstances which enable Aitken particles to activate at cloud base: (1) rapid cooling rates, generally associated with higher updraft speeds, increase cloud base supersaturation; and (2) very low concentrations of larger particles $(>100 \mathrm{~nm})$, which reduce water vapour uptake at cloud base, thereby increasing supersaturations. In the second case, which is prominent in the Arctic during summer, modelling suggests that even modest updrafts $\left(20-50 \mathrm{~cm} \mathrm{~s}^{-1}\right)$ lead to the activation as CCN of particles as small as $40 \mathrm{~nm}$ (Korhonen et al., 2008b, a). This had never previously been verified by observations and was a main focus of the NETCARE summertime flight campaign.

During the NETCARE flights conducted out of Resolute Bay in July 2014, number size distributions of cloud droplets and aerosol particles measured in and around clouds showed that $50 \mathrm{~nm}$ particles were routinely activated and that particles as small as $20-30 \mathrm{~nm}$ were activated on a few occasions where updraft speeds were likely higher (Leaitch et al., 2016). These results substantiate the prediction made by Korhonen et al. (2008b). However, Leaitch et al. (2016) found no evidence for an association of cloud liquid water content with aerosol variations when droplet concentrations are less than about $10 \mathrm{~cm}^{-3}$, which was proposed by Mauritsen et al. (2011) as a means of aerosol-induced longwave warming. Modelling conducted as part of NETCARE demonstrated the importance of this Aitken particle activation. For example, as mentioned above, Croft et al. (2016a) estimated the Arctic summertime shortwave radiative forcing by the effects of natural seabird ammonia emissions on these particles at $-0.5 \mathrm{~W} \mathrm{~m}^{-2}$, highlighting the importance of this natural aerosol for climate.

Lastly, experiments are in progress to evaluate the Single Column Model of Arctic Boundary Layer Clouds (SCMABLC) and version 18 of the Canadian Climate Centre's radiative transfer model with the cloud observations conducted from Resolute Bay discussed above. The modelling work will attempt to reproduce the observations and quantify the uncertainty in modelling the radiative balance of low clouds and fog in the summertime Arctic. 

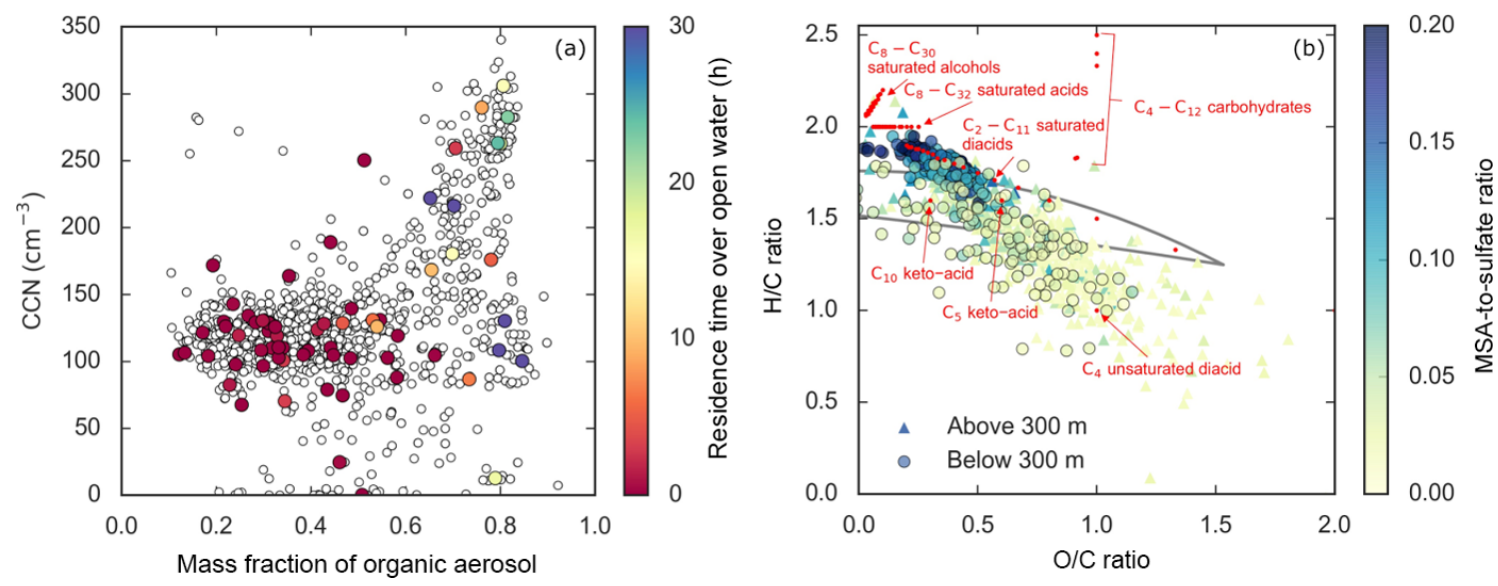

Figure 8. Panel (a) illustrates that the number of CCN (at $0.6 \%$ supersaturation) measured by NETCARE in the summertime Arctic in 2014 is related to the organic mass fraction of the particles measured by an aerosol mass spectrometer. Open circles are all the data points. The closed, coloured circles represent the FLEXPART-WRF predicted air mass residence time over open water in the boundary layer prior to the measurement (see Willis et al., 2017, for details). Panel (b) plots the $\mathrm{H} / \mathrm{C}$ vs. the $\mathrm{O} / \mathrm{C}$ ratios of submicron aerosol measured during the same summertime 2014 campaign. The circles and triangles are low $(<300 \mathrm{~m})$ and high $(>300 \mathrm{~m})$ altitude points, respectively, and the colour is the MSA-to-sulfate ratio of the aerosol. High ratios indicate large biogenic secondary impact. The convergence of points with high ratios to an $\mathrm{H} / \mathrm{C}$ ratio close to 2 indicates a composition with substantial hydrocarbon-like character, as indicated in red by the placements for common molecules. Figures from Willis et al. (2017).

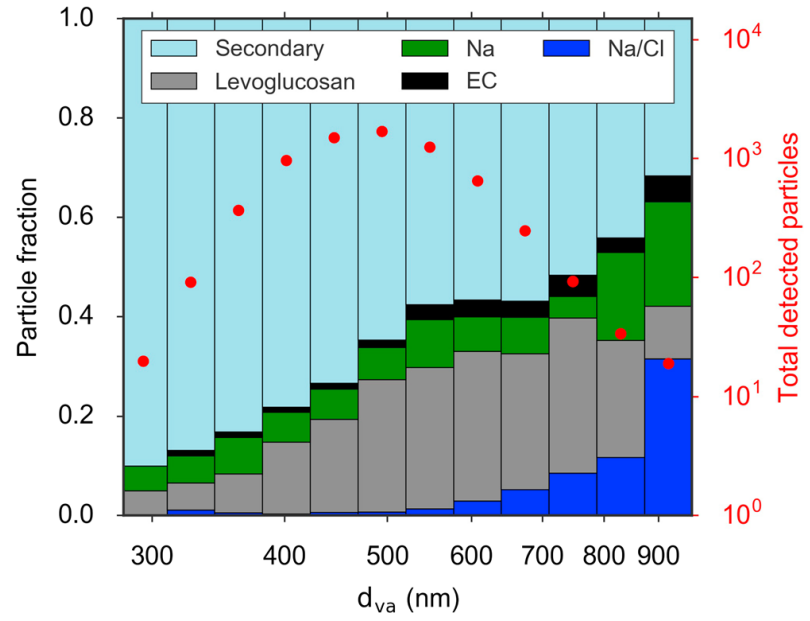

Figure 9. Single-particle mass spectrometry results from the NETCARE 2014 summer campaign, where the detected particle fraction is plotted against the aerodynamic diameter of the particle. The total number of particles detected in a specific size bin is plotted in red. The classifications of particle types containing different species are: $\mathrm{Na} / \mathrm{Cl}$ (dark blue), levoglucosan (grey), $\mathrm{Na}$ (green), elemental carbon (EC, black), and a category of particles called "Secondary" that includes organics, potassium, sulfate, trimethylamine, and MSA (light blue). Figure from Willis et al. (2017).

\subsection{Springtime aerosol: sources and vertical distribution}

As discussed in Sect. 2, Arctic haze is a prominent feature in springtime, yet its composition and sources remain uncertain.

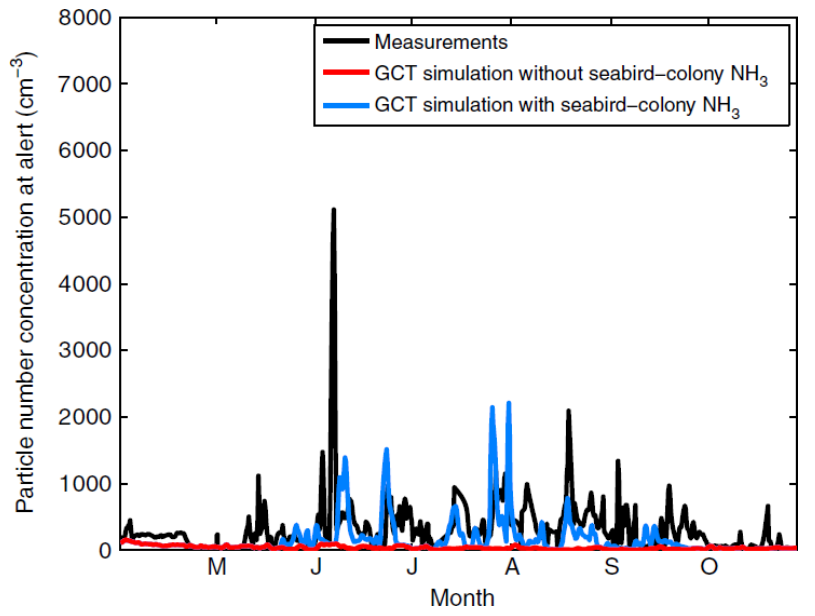

Figure 10. Time series of measured and modelled numbers of particles $10 \mathrm{~nm}$ and larger at Alert during 2011. Seabird ammonia is included in the blue curve simulation but not in the red curve simulation. Measurements are in black. Figure from Croft et al. (2016a). GCT represents GEOS-Chem-TOMAS.

During the NETCARE 2015 aircraft campaign, vertically resolved observations of trace gases and aerosol composition were made in the high Arctic springtime, with six flights north of $80^{\circ} \mathrm{N}$. Trace gas gradients observed on these flights defined the polar dome (i.e. the region north of the Arctic front) as north of $66-68.5^{\circ} \mathrm{N}$ and below potential temperatures of 283.5-287.5 K (Fig. 2; Bozem et al., 2019; Willis et al., 2019). 
NETCARE flight observations based at Alert and Eureka revealed that within the polar dome, submicron aerosol composition varied systematically with potential temperature. In the lower polar dome (i.e. below $252 \mathrm{~K}$ ), measured aerosol mass (non-refractory aerosol and $\mathrm{BC}$ ) was dominated by sulfate $(74 \%)$, with smaller contributions from $\mathrm{BC}(1 \%)$, organic aerosol (OA, $20 \%$ ), and ammonium $\left(\mathrm{NH}_{4}, 4 \%\right)$. At higher altitudes and warmer potential temperatures, BC, OA, and $\mathrm{NH}_{4}$ contributed up to $3 \%, 42 \%$, and $8 \%$ of aerosol mass, respectively. These observations indicate a substantial but unquantified contribution from sea salt aerosol in the lower polar dome (Leaitch et al., 2018; Willis et al., 2019). Vertically resolved observations suggest that measurements at the surface may underestimate the contribution of OA, $\mathrm{BC}$, and $\mathrm{NH}_{4}$ to aerosol transported to the Arctic troposphere (Schulz et al., 2019; Willis et al., 2019). Next, we discuss hypotheses that may explain this vertical variability in aerosol composition.

Model simulations of air mass history using FLEXPART indicate differences in transport history as a function of potential temperature in the polar dome. Air masses at lower potential temperature (lower altitude) spent long times (> 10 days) in the polar dome, while air masses at higher potential temperature (higher altitude) had entered the Arctic more recently and were more recently influenced by lower latitude sources at the surface (Willis et al., 2019). Model results indicate that descent of air masses from higher potential temperatures influenced the lower polar dome on the timescale of 10 days. Submicron aerosol composition varied systematically with model-predicted time spent in the mid-to-lower polar dome (i.e. below $265 \mathrm{~K}$ ): the sulfate fraction increased with time below $265 \mathrm{~K}$, while the $\mathrm{NH}_{4}, \mathrm{OA}$, and $\mathrm{BC}$ fractions decreased significantly. These phenomena could arise from a combination of three possible processes: (1) systematic changes in source region with increasing potential temperature (Fisher et al., 2011) that supply aerosol with systematically different compositions, (2) oxidation of transported aerosol and sulfur dioxide over the long aerosol lifetime in the polar dome and during transport, and (3) wet removal and cloud processing along the transport path that may impact the composition of aerosol arriving in the polar dome.

An analysis of results from simulations with four different models in NETCARE (Mahmood et al., 2016) indicates that the main source of $\mathrm{BC}$ in the Arctic is long-range transport from mid-latitudes. The long-range transport of $\mathrm{BC}$ to the Arctic is particularly efficient in midwinter and then decreases in efficiency, reaching a minimum in March and April. At the same time, dry deposition decreases, and wet deposition from clouds in the low and mid troposphere becomes more important during the transition from winter to spring. Overall, sources and sinks of BC in the Arctic are well balanced, leading to nearly steady Arctic burdens during the time period from December to May. Subsequently, during the transition from spring to summer, precipitation increases and wet deposition becomes highly efficient, which leads to substantial reductions in $\mathrm{BC}$ burdens in the Arctic despite increased emissions from vegetation fires. At high altitudes in the Arctic, the model results indicate that convective transport of pollution from the lower to the upper troposphere at lower latitudes and subsequent long-range transport to the Arctic represents an important source of BC.

$\mathrm{Xu}$ et al. (2017) interpreted a series of airborne and ground-based BC measurements made using multiple measurement techniques with the GEOS-Chem global chemical transport model and its adjoint to attribute the sources of Arctic BC (Fig. 11). This was the first comparison of BC measurements from a Single Particle Soot Photometer (SP2) at Alert with a chemical transport model. The inclusion of seasonally varying domestic heating and of gas-flaring emissions was crucial to successfully simulating ground-based measurements of BC concentrations at Alert and Barrow and airborne BC measurements across the Arctic. Sensitivity simulations suggest that anthropogenic emissions in eastern and southern Asia have the largest effect on the Arctic BC column burden in spring $(56 \%)$, with the largest contribution in the middle troposphere. At the Arctic surface, anthropogenic emissions from northern Asia (40\%-45\%) and eastern and southern Asia (20\%-40\%) are the largest BC contributors in winter and spring, followed by Europe (16\%$36 \%$ ). This dominant role of Asian sources is consistent with some recent studies (e.g. Ma et al., 2013; Wang et al., 2014; Ikeda et al., 2017) but differs from many earlier studies (e.g. Stohl, 2006; Shindell et al., 2008; Gong et al., 2010; Huang et al., 2010; Bourgeois and Bey, 2011; Sharma et al., 2013) due to decreased European emissions and increased Asian emissions. The adjoint simulations enabled identification of pronounced spatial heterogeneity in the contribution of emissions to the Arctic BC column concentrations, with noteworthy contributions from emissions in eastern China (15\%) and western Siberia (6.5\%). The Tarim oilfield in western China stood out as a specific influential source with an annual contribution of $2.6 \%$. Emissions from as far away as the IndoGangetic Plain could have a substantial influence $(6.3 \%)$ on Arctic BC as well.

\subsection{Springtime aerosol: optical properties}

Kodros et al. (2018) combined measurements of BC mixing state in the springtime Canadian high Arctic with simulated size-resolved aerosol mass and number concentrations to constrain model estimates of the direct radiative effect (DRE). Airborne measurements using an SP2 (soot particle photometer) and Ultra-High Sensitivity Aerosol Spectrometer on board the Polar 6 aircraft show an average coating thickness of 45 to $40 \mathrm{~nm}$ for BC core diameters across the range of 140 to $220 \mathrm{~nm}$, respectively. For total particle diameters ranging from 175 to $730 \mathrm{~nm}$, BC-containing particle number fractions range from $16 \%$ to $3 \%$. GEOS-ChemTOMAS yields a pan-Arctic average springtime DRE for all 


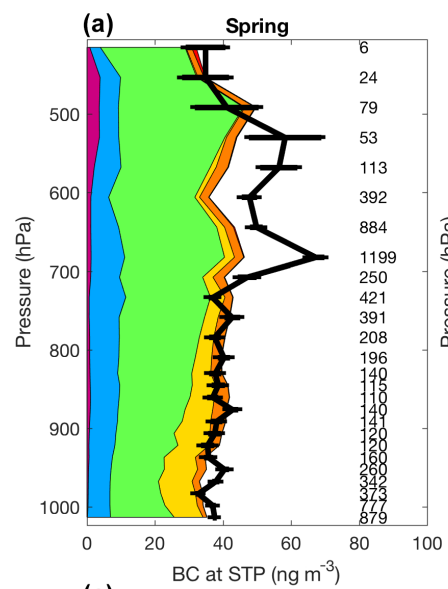

(c)
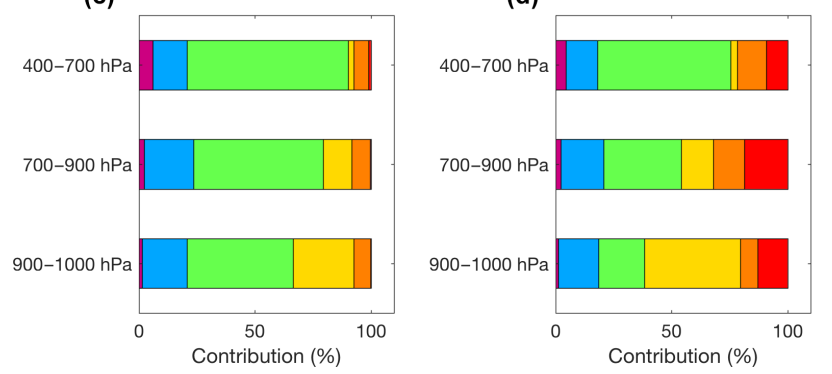

Figure 11. GEOS-Chem adjoint modelling results for BC sources to the Arctic. Panels (a) and (b) show in colour the contributions of BC from different anthropogenic emission and biomass burning regions to the vertical profiles in the atmosphere, where the measurements are in black. Modelled results are for the entire Arctic for the annual average. The data are binned in pressure ranges in panels (c) and (d). Numbers of measurements are along the $y$ axis. Figure from $\mathrm{Xu}$ et al. (2017).

aerosols ranging from $-1.65 \mathrm{~W} \mathrm{~m}^{-2}$ when assuming entirely externally mixed $\mathrm{BC}$ to $-1.34 \mathrm{~W} \mathrm{~m}^{-2}$ when assuming entirely internally mixed BC. Using the observed mixing-state constraints from this field campaign significantly reduces this estimated range in DRE by over a factor of $2(-1.59$ to $-1.45 \mathrm{~W} \mathrm{~m}^{-2}$ ). Measurements of mixing state thus provide important constraints for model estimates of the DRE.

Some of the first vertically resolved and concurrent measurements of aerosol composition and optical properties in the springtime high Arctic are presented in Leaitch et al. (2019). As shown in Fig. 12a, observations from the Polar 6 during April 2015 indicate an increase in the fraction of refractory black carbon $(\mathrm{rBC})$ in submicron particles with altitude coincident with an increase in the overall carbonaceous fraction of the submicron aerosol for flights conducted around Alert, Nunavut, and Eureka, Nunavut (Schulz et al., 2019; Willis et al., 2019). For values of the light scattering coefficient $\left(\sigma_{\text {scat }}\right)$ less than $15 \mathrm{Mm}^{-1}$, which represent $98 \%$ of the measured $\sigma_{\text {scat }}$ during the Alert and Eureka flights, the single scattering albedo (SSA) of the aerosol decreases from 0.96 near the surface to 0.93 at $500 \mathrm{hPa}$ (Fig. 12a). The SSA

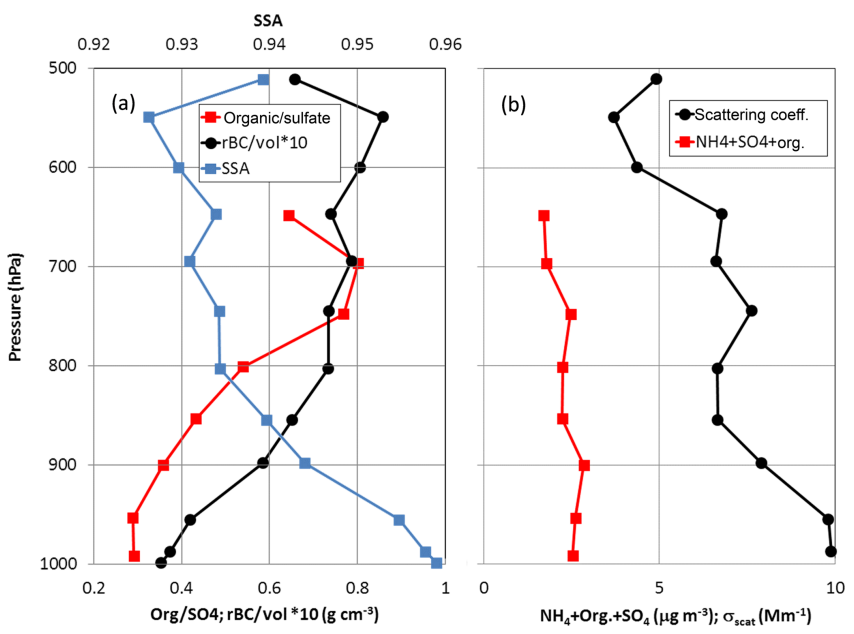

Figure 12. (a) Vertical profiles of the ratio of organic material to sulfate (Organic/sulfate) from Willis et al. (2019), the ratio of refractory black carbon $(\mathrm{rBC})$ to the volume concentration of the submicron aerosol estimated from the measured size distribution (Schulz et al., 2019) and one estimate of the single scatter albedo (SSA; Leaitch et al., 2019). (b) Profiles of the sum of the mass concentrations of ammonium $\left(\mathrm{NH}_{4}\right)$, organic material (Org.) and sulfate $\left(\mathrm{SO}_{4}\right)$ with the light scattering coefficient $\left(\sigma_{\text {scat }}\right)$. All values are medians over approximately $50 \mathrm{hPa}$ pressure intervals. Results are for flights conducted out of Alert and Eureka, and constrained to $\sigma_{\text {scat }}<15 \mathrm{Mm}^{-1}$, which represents $98 \%$ of the observed $\sigma_{\text {scat }}$.

decrease with altitude is consistent with the increasing fraction of $\mathrm{rBC}$ in the particles and suggests a stabilizing influence of $\mathrm{BC}$ on the high Arctic atmosphere. In an absolute sense, the $\sigma_{\text {scat }}$ values primarily vary with the sum of ammonium, organics, and sulfate as shown in Fig. 12b.

\subsection{Monitoring the transitions between seasons by remote sensing}

While in situ field campaigns provide detailed information over a short period of time, remote sensing provides annual measurements and thus information about the transitions from winter to spring and then into summer. In particular, ground-based lidar and star photometry (carried out at the PEARL observatory in Eureka, Nunavut) and satellitebased lidar (CALIOP/CALIPSO) during the latter half of two polar winters suggest the frequent Arctic-wide presence of submicron particles in the boundary layer with aerosol optical depths (AODs) significantly greater than the AOD predicted by GEOS-Chem, in which the AOD largely results from sulfate particles (O'Neill et al., 2016). Ground-based sun photometry (AEROCAN/AERONET) measurements acquired between 2009 and 2012 at five western-Arctic stations (Hesaraki et al., 2017) revealed Arctic-wide springtime peaking of both submicron and super-micron AODs that were roughly consistent with submicron and super-micron AOD estimates from GEOS-Chem (predominantly associated with 
Arctic haze sulfates and Asian mineral-dust aerosols, respectively). A summertime peak in submicron particles, which was determined to be smoke induced at the four westernmost AEROCAN Arctic stations, was not simulated by GEOSChem. Rather, GEOS-Chem indicated a continuous springto-fall decrease in submicron AOD that was principally associated with a decrease in sulfate contributions.

\subsection{Aerosol deposition to snow}

Deposition fluxes in the Arctic are very poorly characterized, in large part because of the logistical challenges of collecting continuous data series. To address this, NETCARE scientists collected temporally resolved data for the chemical composition of snow (common metals, BC, soluble ions, and small organics) that fell throughout the cold season at Alert (Macdonald et al., 2017). In particular, new snow was collected after each appreciable period of precipitation, resulting in samples every 4 days, on average, from September 2014 to May 2015.

Using measurements of the amount of snow that had fallen in a given area, the chemical compositions were converted to fluxes for comparison with modelled values. In combination with ambient air concentrations of the equivalent chemical species, the measured fluxes were then expressed as an effective deposition velocity, which encompasses both wet and dry deposition processes (Fig. 13; Macdonald et al., 2017). Interestingly, effective deposition velocities are higher for the warmest months (September, October, May) than for the cold months, arising from the switchover from liquid water to a combination of dry deposition and ice cloud scavenging. The effective deposition velocities for $\mathrm{BC}$ were the smallest of all species characterized, consistent with its low hygroscopicity and poor ice-nucleating abilities.

To take advantage of the high temporal resolution of the samples, the data were also used to assess potential sources contributing to chemical species in snow using a combination of positive matrix factorization and FLEXPART potential emission sensitivity analysis (Macdonald et al., 2018). The best positive matrix factorization solution consisted of seven source factors (sea salt, crustal metals, BC, carboxylic acids, nitrate, non-crustal metals, and sulfate), reflecting a balance between natural and anthropogenic sources. Notable findings include identification of anthropogenic sources (but not biomass burning) as dominant for $\mathrm{BC}$ during this study period, and a potential source of volcanic sulfur in the fall of 2014.

A simple parameterization of $\mathrm{BC}$ in snow was developed and tested in the Canadian Atmospheric Global Climate Model (CanAM). According to the parameterization, the temporal evolution of the concentration of $\mathrm{BC}$ near the top of the snowpack is determined by changes in dry and wet deposition of $\mathrm{BC}$, the snowfall flux and scavenging by snow meltwater. Comparison of model results with a multiyear climatology of $\mathrm{BC}$ concentrations in snow produces

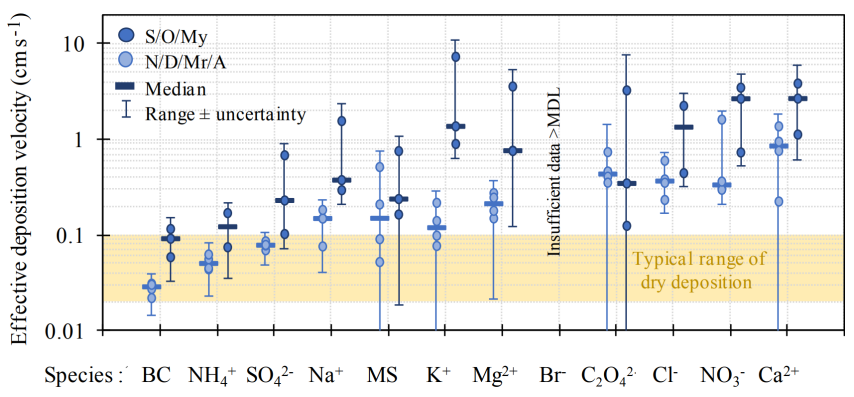

Figure 13. The monthly average (circles) effective deposition velocity of different chemical species to snow at Alert during 20142015. Median values (bars) are also shown. The effective deposition velocity encompasses both wet and dry deposition processes. In general, the warmer months have higher deposition velocities than the colder months, likely due to enhanced wet deposition in the former. Figure from Macdonald et al. (2017).

good agreement for locations in the Canadian Arctic and subArctic (Doherty et al., 2010, 2014; X. Wang et al., 2013) as well as for other regions in the Northern Hemisphere (Namazi et al., 2015). Simulated changes in BC loading in snow in the second half of the 20th century had much smaller cryospheric impacts on surface air temperatures than other aerosol and greenhouse gas radiative forcings.

\subsection{Ship emissions}

Understanding the impacts of ship emissions on climate and air quality of the Arctic environment is challenging but important, given the likelihood of future increases in Arctic shipping (Corbett et al., 2010; Pizzolato et al., 2014; Winther et al., 2014). The Arctic atmospheric boundary layer exhibits different dynamics from mid-latitudes, being characterized by thermally stable conditions with reduced turbulent mixing (Aliabadi et al., 2016a). Ships navigating northern latitudes operate under partial engine load and ice-breaking conditions as opposed to full speed cruising. Uncertainties are compounded by the lack of accurate predictions for increased ship traffic patterns in the Arctic as the ice cover retreats, as well as the lack of a robust regulatory framework to control emissions via emission control areas set by the International Maritime Organization (Aliabadi et al., 2015).

The NETCARE campaign near Resolute Bay in July 2014 characterized typical ship emissions and plume evolution by mapping the plume of the CCGS Amundsen with the Polar 6 research aircraft (Aliabadi et al., 2016b). Three plumes were intercepted, with the first corresponding to operation of the CCGS Amundsen in open water under low-speed cruise conditions, while the second and third corresponded to operation under ice-breaking conditions. The measured species included mixing ratios of $\mathrm{CO}_{2}, \mathrm{NO}_{x}, \mathrm{CO}, \mathrm{SO}_{2}$, particle number concentration, $\mathrm{BC}$, and $\mathrm{CCN}$. Lower plume expansion rates were observed compared to mid-latitudes due to reduced turbulent mixing, resulting in a poorly diluted plume that was 
confined within a low boundary layer. Most, but not all, emission factors agreed with prior observations for low engine loads at mid-latitudes. This implied different emission factors for each species measured. In particular, ice-breaking increased the $\mathrm{NO}_{x}$ emission factor to values equivalent to those measured for high engine loads at mid-latitudes, likely due to differences in engine combustion temperatures. The $\mathrm{CO}$ emission factor was higher at low engine loads, whereas the $\mathrm{BC}$ emission factors were similar to those at mid-latitudes; the effect of engine load on BC emission factors is still debated in the literature. While various authors report increasing emission factors by decreasing engine loading (Agrawal et al., 2008; Petzold et al., 2010, 2011; Khan et al., 2012), other authors report decreasing emission factors by decreasing engine loading (Cappa et al., 2014). Due to the use of low sulfur diesel fuel by the CCGS Amundsen, no $\mathrm{SO}_{2}$ was detected.

\section{Ice nucleating particles}

\subsection{Rationale and research questions}

Currently, clouds are responsible for some of the greatest uncertainties in climate change predictions. This is in large part because the properties of clouds and their formation processes are poorly understood, especially in the case of ice and mixed-phase clouds (Cantrell and Heymsfield, 2005; Hegg and Baker, 2009; Murray et al., 2012). Particles that can initiate ice formation in the atmosphere at temperatures and relative humidities lower than those required for homogeneous freezing of solution droplets are referred to as ice nucleating particles (INPs; Vali et al., 2015). Only a very small fraction of atmospheric particles ( 1 in $10^{-3}$ to $10^{-5}$ ) can act as INPs (Rogers et al., 1998), but predictions of climate and precipitation can depend strongly on INP concentrations (DeMott et al., 2010; Lohmann, 2002). As an example, an increase in the concentrations of INPs can lead to more precipitation and shorter cloud lifetimes for mixed-phase clouds, resulting in less solar reflectivity (DeMott et al., 2010; Lohmann, 2002). Despite the importance of INPs, the level of scientific understanding of their concentrations and sources in the atmosphere remains low (Coluzza et al., 2017). To improve predictions of precipitation and climate in the Arctic, the concentrations and sources of INPs in this region need to be determined. This information can then be used to test and constrain parameterizations in atmospheric models (VergaraTemprado et al., 2017).

\subsection{INPs in the sea surface microlayer and bulk sea water}

The sea surface microlayer is the interface between the atmosphere and the ocean and is a source of particles to the atmosphere via wave-breaking and bubble-bursting. INPs have previously been detected in bulk seawater (Schnell, 1977;
Schnell and Vali, 1975, 1976); however, concentrations and properties of INPs in the microlayer have not been confirmed prior to the start of NETCARE. This lack of information led to large uncertainties in quantifying the importance of the microlayer as a source of INPs to the atmosphere (Burrows et al., 2013). In initial experiments, the concentration of INPs in the microlayer collected off the west coast of Canada were measured (Wilson et al., 2015); while in parallel, researchers from the University of Leeds measured the properties and concentrations of INPs in the microlayer collected off the east coast of the United States and Greenland (Wilson et al., 2015). We built on this work by measuring the concentrations and properties of INPs in the microlayer collected in the Canadian Arctic (Irish et al., 2017, 2018).

Microlayer samples were collected in the Canadian Arctic during the summers of 2014 and 2016 from the CCGS Amundsen. INPs were ubiquitous in the microlayer with freezing temperatures as warm as $-5^{\circ} \mathrm{C}$. Concentrations of INPs were higher on average in 2016 than in 2014 or off the east coast of the US and Greenland (Wilson et al., 2015). The INP concentrations were enhanced in the microlayer compared to bulk seawater in several samples collected in 2016 . Concentrations of INPs were anti-correlated with salinity, possibly indicating that the INPs were associated with melting sea ice. The INPs had diameters between 0.2 and $0.02 \mu \mathrm{m}$ and were heat-labile, and therefore likely biological material. Possible candidates for the INPs include exudates from seaice microorganisms such as sea-ice diatoms and bacteria.

\subsection{INPs in the high Arctic during spring-summer}

The size of INPs collected from the atmosphere at Alert in late spring and early summer 2014 were also measured (Mason et al., 2016). The size of atmospheric INPs can help distinguish which types of atmospheric particles are important as INPs. During this campaign, the average concentrations of atmospheric INPs were $0.05,0.22$, and $0.99 \mathrm{~L}^{-1}$ at freezing temperatures of $-15,-20$, and $-25^{\circ} \mathrm{C}$, respectively. The median diameters of the INPs were $3.2,2.2$, and $0.83 \mu \mathrm{m}$ at freezing temperatures of $-15,-20$, and $-25^{\circ} \mathrm{C}$, respectively, and the average fractions of INPs $\geq 1 \mu \mathrm{m}$ were $95 \%$, $66 \%$, and $41 \%$ at freezing temperatures of $-15,-20$, and $-25^{\circ} \mathrm{C}$, respectively. These results suggest that the major sources of the INPs at this site during the collection period were not submicron aerosol particles, such as ammonium sulfate, and BC particles. The sizes of the INPs measured at Alert were consistent with those of INPs measured at five other sites in North America, as well as one in Europe (Mason et al., 2016).

During March 2016, INP measurements at Alert were made daily ( $\mathrm{Si}$ et al., 2018). In these high-frequency data, INP concentrations were strongly correlated with tracers of mineral dust at a freezing temperature of $-25^{\circ} \mathrm{C}$, suggesting that it was a major source of the INPs measured at this temperature. These results are consistent with the size of INPs 


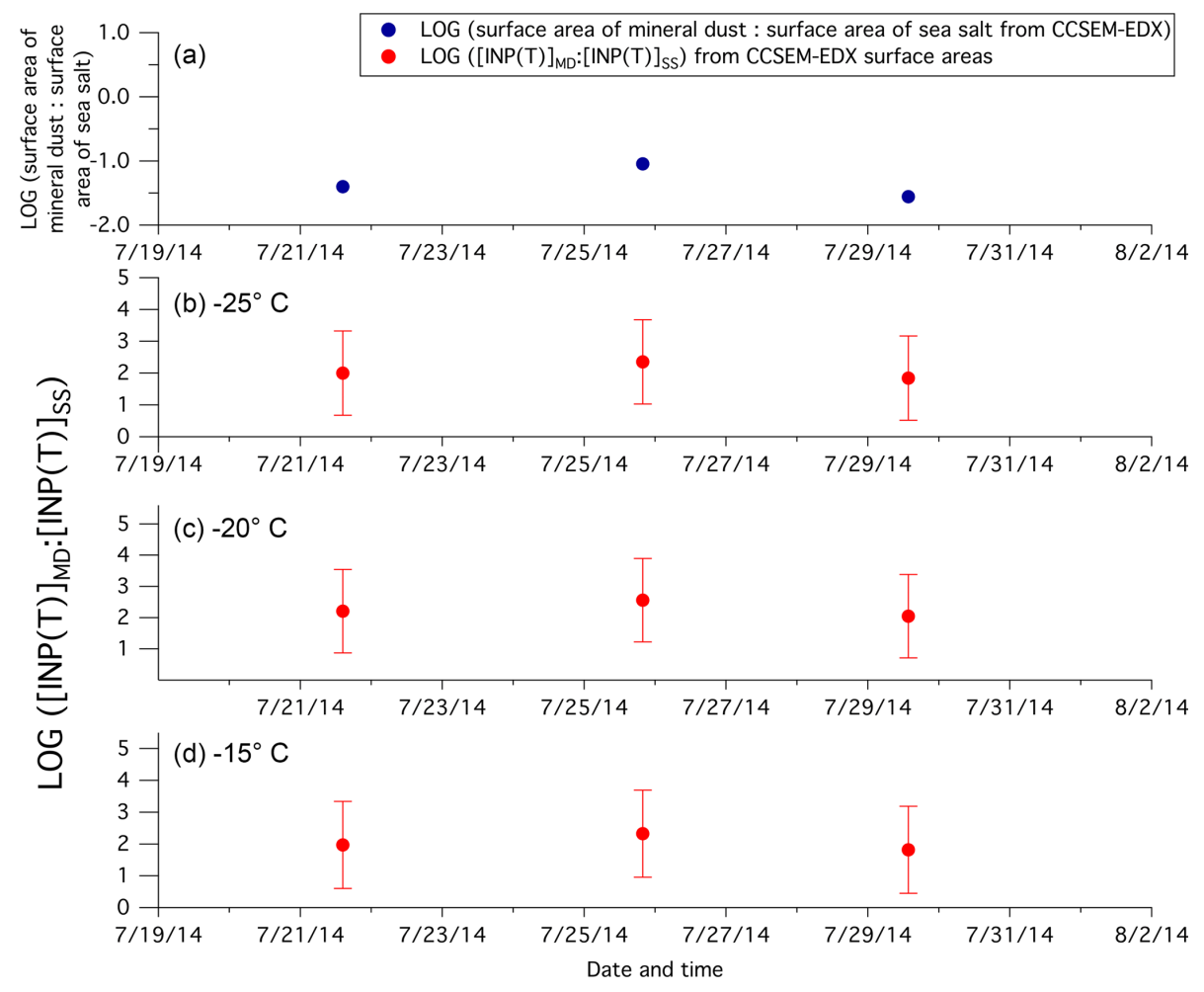

Figure 14. Results from measurements in the Arctic marine boundary layer during summer 2014 (Irish et al., 2019). (a) Ratios of the surface area of mineral dust particles to the surface area of sea salt particles measured by computer controlled scanning electron microscopy with energy-dispersive X-ray spectroscopy (CCSEM-EDX). Ratios of predicted INP concentrations from mineral dust, [INP(T)]MD, to the predicted INP concentrations from sea spray aerosol, $[\mathrm{INP}(\mathrm{T})]_{\mathrm{SS}}$, are calculated using CCSEM-EDX measurements at temperatures of (b) $-25^{\circ} \mathrm{C},(\mathbf{c})-20^{\circ} \mathrm{C}$, and $(\mathbf{d})-15^{\circ} \mathrm{C}$. Results show that mineral dust is a more important contributor to the INP population in the Arctic than sea spray aerosol at these times and locations.

measured at Alert during the spring and summer of 2014. Particle dispersion modelling suggests that the mineral dust may have been transported over long distances from the Gobi Desert.

\subsection{INPs in the summertime marine boundary layer in the Canadian Arctic Archipelago}

During the summer of 2014, we measured atmospheric concentrations of INPs in the Canadian Arctic marine boundary layer on board the CCGS Amundsen (Irish et al., 2018). Concentrations averaged $0.005,0.044$, and $0.154 \mathrm{~L}^{-1}$, at freezing temperatures of $-15,-20$, and $-25^{\circ} \mathrm{C}$, respectively. These values fell within the range of atmospheric concentrations measured at locations outside the Arctic and in the marine boundary layer (DeMott et al., 2016). Based on a combination of surface area measurements of mineral dust and sea spray aerosol (Fig. 14) and particle dispersion modelling using FLEXPART, mineral dust from local sources is a more important contributor than sea spray aerosol to the atmospheric INP population for the times and locations studied. These results do not rule out the sea surface microlayer as a source of INPs to the Arctic marine boundary layer; rather, they show that the sea surface microlayer is likely a smaller source of atmospheric INPs compared to local mineral dust for the locations and times studied, at least at a freezing temperature of $-25^{\circ} \mathrm{C}$.

\subsection{Measurements of thin ice cloud microphysics linked to INP properties}

Sulfuric acid coatings strongly affect INPs and thus their effect on clouds and precipitation. This is particularly important during Arctic haze events. Laboratory studies (Eastwood et al., 2009), in situ measurements (Jouan et al., 2014), and large-scale observations from the CloudSat and CALIPSO satellites (Grenier et al., 2009; Grenier and Blanchet, 2010) support the hypothesis of a dehydration-greenhouse feedback (Blanchet and Girard, 1994) linking acidified aerosols to the favoured formation of larger ice crystals and light precipitation through a reduction of INP activity. In cold Arctic conditions, thin ice clouds (TIC), like cirrus, are ubiquitous in the coldest free troposphere (Grenier et al., 2009). Two types have been identified: TIC-1, which has many small crystals (smaller than $\sim 30 \mu \mathrm{m}$ ), and TIC-2, which has fewer but larger ice crystals. While TIC-1 is largely non- 
precipitating, TIC-2 leads to light precipitation, often in the form of diamond dust, which is sometimes called clear sky precipitation because of the very low optical depth of the clouds. Acidic INPs favour the formation of TIC-2 in the middle and upper troposphere, which enhances water flux towards the lower layers and leads to dehydration of the upper cold troposphere. In turn, this process lowers the greenhouse effect of water vapour and favours the direct IR cooling of the air mass in the lower atmosphere and at the surface. Hence, variations in the INP composition can significantly affect the radiative properties of the polar atmosphere and clouds, as well as the atmospheric moisture concentration.

A far IR radiometer (FIRR) developed with Canadian Space Agency support and especially designed to measure TIC properties and water vapour was flown on board the Polar 6 aircraft during the NETCARE campaign of April 2015. The goal was to simultaneously measure, for the first time, INPs, cloud microphysics, and spectrally resolved radiation in the range of 8 to $50 \mu \mathrm{m}$ over the Arctic. The experiment successfully demonstrated closure between measurements and theoretical calculations for clear-sky conditions (Libois et al., 2016a, b). It also showed the strong sensitivity of FIRR observations to ice crystal size and cloud optical depth. However, the limited number of ice clouds encountered and the complexity inherent in probing them with an aircraft highlighted the need for further campaigns dedicated to simultaneous investigation of ice cloud radiative and microphysical properties (Libois et al., 2016b). The results obtained from the NETCARE campaign have paved the way for a future satellite-based deployment over the poles, linking cloud microphysics, the atmospheric water budget, and radiation balance.

\section{Remaining uncertainties in Arctic aerosol research}

The NETCARE research outlined above has provided novel insights into (1) the biogenic sources of gases that can impact the size and composition of Arctic aerosol; (2) new particle formation and growth into sizes that were demonstrated to be activating to form cloud droplets, with growth occurring largely via formation of Arctic marine secondary aerosol; (3) the sources and properties of Arctic haze aerosol, in particular BC-containing particles; (4) Arctic INPs in the air, ocean water, and the sea surface microlayer; and (5) deposition rates of pollutants to snow. Many of these advances arose as a result of the highly interdisciplinary approach taken within NETCARE. Nevertheless, despite these advances, many research questions remain, as outlined in this section.

\subsection{Marine and coastal biogenic aerosol precursors}

Observations gathered during NETCARE provide a valuable benchmark upon which to base predictions of the changes in the source strength of secondary MBA precursors in response to alterations in Arctic climate. This is important for determining the amounts of both aerosol sulfate and organics. The thinning and loss of seasonal sea ice, which is driven by warming and polar amplification, is by far the most conspicuous of these alterations (AMAP, 2013; Comiso, 2011; Serreze and Barry, 2011).

The marine production of DMS could be particularly sensitive to both modifications in seasonal ice extent and the intermittent presence of melt ponds above the ice in spring and summer (Gabric et al., 2017; Gourdal et al., 2018; Lizotte et al., 2019). Modelling and observational studies suggest that the northward shrinking of the seasonal ice extent and the ensuing increase in open waters available for gas exchange could lead to heightened primary productivity (Arrigo and van Dijken, 2015; Gabric et al., 2017; Ito and Kawamiya, 2010) and production of DMS (Levasseur, 2013). In turn, this would lead to higher atmospheric MSA and secondary sulfate (Sharma et al., 2012), and background particle concentrations (Dall'Osto et al., 2017). Simulations with CanAM indicate that associated increases in concentrations of $\mathrm{CCN}$ could potentially offset part of the warming due to enhanced cloud albedo (Mahmood et al., 2018). Specifically, the projected loss of sea ice between 2000 and 2050 leads to a substantial increase in Arctic DMS emissions in CanAM, leading the cloud radiative forcing associated with Arctic DMS to increase from -0.13 to $-0.27 \mathrm{~W} \mathrm{~m}^{-2}$ during this time period if marine production of DMS is unchanged. Adding to these wide-ranging observations and modelling outputs, NETCARE results suggest that as seasonal (i.e. first-year) sea ice becomes a pan-Arctic feature in the future (AMAP, 2017), ice-related sources of DMS could increase in response to the thinning of sea ice, as well as to the areal and temporal expansion of melt ponds that act both as a source of DMS and as a catalyst of under-ice bloom development. Conversely, observational and modelling studies also suggest that increased stratification in ice-free waters of the Arctic could curb primary productivity due to nutrient limitation (Steiner et al., 2015) and that wind-induced sea spray may be more prevalent in open waters, acting as a condensation sink for material that could form secondary aerosol (Browse et al., 2014)

The Arctic system may also be vulnerable to other changes, notably ocean acidification, as well as amplified warming and freshwater inputs (AMAP, 2013; YamamotoKawai et al., 2009). An experimental assessment of the impact of ocean acidification on DMS-producing planktonic communities of Baffin Bay during NETCARE (Hussherr et al., 2017) revealed that DMS production may decrease by $25 \%$ under end-of-the-century scenario reductions of $\mathrm{pH}$ $\left(\Delta \mathrm{pH}_{T}=-0.48\right)$, confirming results observed in another Arctic study in the Svalbard archipelago which showed a $35 \%$ decrease in DMS production (Archer et al., 2013). Other studies, however, have suggested that organisms thriving in Arctic waters may already be resilient to moderate or 
acute natural fluctuations in $\mathrm{pH}$, exhibiting a high capacity to compensate for modifications in $\mathrm{pH}$ (Hoppe et al., 2018) and no significant changes in DMS following acidification (Hopkins et al., 2018). Further experimentation is needed to identify the underlying causes for these contrasting DMS responses to ocean acidification in Arctic waters.

NETCARE illustrated for the first time the influence of ammonia emissions from seabird colonies on not only atmospheric mixing ratios (Wentworth et al., 2016) but also new particle formation, aerosol neutralization, and associated indirect effects on climate (Croft et al., 2016a, 2018). How will these emissions evolve with climate change and potential changes in wildlife populations (Weimerskirch et al., 2018), habitat, and migratory patterns? NETCARE measurements from Alert suggest that Arctic soils may also be an ammonia source (Murphy et al., 2019), perhaps reflecting the redistribution of ammonia between different components of the Arctic land-ocean ecosystem. This highlights the importance of including bidirectional fluxes in chemical transport models for species that move readily between the land, atmosphere, and ocean.

\subsection{Particle and SOA formation in summertime Arctic marine environments}

Unlike lower-latitude marine boundary layers (Quinn and Bates, 2011) particle nucleation and growth was frequently observed during NETCARE campaigns in the boundary layer in Arctic marine and coastal regions. The Arctic may behave differently for a number of reasons: (1) the persistent temperature inversion lowers the rate of mixing of surface emissions; (2) the summertime atmosphere has 24-hour sunshine to drive photo-oxidation; (3) the condensation sink is particularly low; and (4) the low temperatures facilitate molecular cluster formation. It is crucial to assess the chemical components and particle formation mechanisms that prevail in this distinctive environment. Particularly valuable will be on-line mass spectrometric measurements of the chemical composition of the smallest clusters and particles that form at the early stages of the nucleation and growth process.

The growth of $5-50 \mathrm{~nm}$ particles into $\mathrm{CCN}$ size ranges was evident in multiple NETCARE campaigns (Burkart et al., 2017a, b; Collins et al., 2017; Willis et al., 2016, 2017). Surprisingly, much of the submicron aerosol mass associated with growth was organic in composition (Burkart et al., 2017b; Willis et al., 2016, 2017), providing additional support to the idea that secondary organic aerosol of marine origin is important (Rinaldi et al., 2010). Although we do not know the precise nature of the organic precursors, the NETCARE studies described in Sect. 4.2 illustrated that the secondary organic source is marine and potentially associated with oxidation or photochemistry of the sea surface microlayer (see Sects. 3.3 and 6.3). It is important to determine the balance between secondary aerosol formation versus primary particle formation from sea spray. In one NETCARE case study of new particle formation and growth over Lancaster Sound, there were indications of secondary processes occurring alongside formation of sea spray salt particles, suggesting that these processes may sometimes occur simultaneously, complicating analyses (Collins et al., 2017; Köllner et al., 2017; Willis et al., 2016). Key uncertainties in the radiative effects of the Arctic MSOA simulation in GEOS-ChemTOMAS include Arctic nucleation processes, the chemical composition of Aitken particles, and the volatility of the SOA (Croft et al., 2018). Further understanding of these processes would better constrain climate feedbacks. We note that the composition and properties of Arctic MSOA are not necessarily the same as that formed in marine environments in other parts of the world.

\subsection{The sea surface microlayer}

Our understanding of how the sea surface microlayer impacts air-sea exchange of aerosols and gases is still largely circumstantial and is based mainly on conceptual models (Garbe et al., 2014; Lewis and Schwartz, 2013), laboratory experiments (Bigg and Leck, 2008; Wilson et al., 2015), and observations of similarities between particulate matter in the microlayer and the atmosphere (Leck and Bigg, 2005). Obtaining information on how these concepts play out in the real world has proven extremely challenging. That being said, one pronounced example of the potential importance of the sea surface microlayer comes from work in NETCARE that demonstrated that OVOCs in a marine Arctic setting were likely formed photochemically within the microlayer or by oxidation of gases arising from it (Mungall et al., 2017). Although laboratory studies have previously demonstrated that OVOCs can be chemically generated from microlayer surrogate materials (Rossignol et al., 2016; Zhou et al., 2014), such studies do not address the chemical complexity of the genuine environmental system.

Although additional experiments have previously quantified the impact of microlayer surfactant enrichment on gas exchange (Brockmann et al., 1982; Frew et al., 2004; Pereira et al., 2016), to date no one has directly tied natural variations in the sea surface microlayer to the exchange of aerosols or gases. The main difficulty lies in the different temporal and spatial scales of atmospheric and microlayer measurements. The composition of the microlayer is highly heterogeneous even on small horizontal scales (Cunliffe et al., 2013), and recovery of microlayer samples for chemical analysis is time consuming. Thus, tying those measurements to observations of temporally variable aerosols measured from ships or airplanes is innately subject to substantial uncertainties.

In order to confidently identify the relationship between the composition of the sea surface microlayer and atmospheric aerosol production, it will be necessary to collect coherent data sets from single platforms, such as autonomous surface craft (Ribas-Ribas et al., 2017). In addition, intelligently designed time series stations could provide sufficient 
data to identify clear relationships between the microlayer and the atmosphere (Cunliffe et al., 2013; Engel et al., 2017).

\subsection{Removal of aerosol particles in the summertime}

The 2014 NETCARE aircraft campaign illustrated that the low $\mathrm{CCN}$ numbers prevalent in the summer boundary layer can lead to large cloud droplet diameters, in some cases approaching $30 \mu \mathrm{m}$ (Leaitch et al., 2016). The settling velocity of such droplets is sufficiently fast that drizzling low-level clouds and fogs play an important role in deposition to the surface (Browse et al., 2014). As yet, there is no Arctic deposition network that is quantitatively assessing the importance and efficiency of such processes. An important question that arises is the degree to which trends in wet scavenging are driving the trends in aerosol loadings. It is well documented that both aerosol sulfate and BC are currently lower in abundance than they were in previous decades (AMAP, 2015). To what degree is this trend due to reductions in source emissions as opposed to changes in cloud scavenging? In the summer in particular, the wider expanses of open ocean associated with sea-ice melting may lead to higher water fluxes from the ocean to the atmosphere, potentially affecting cloud liquid water content and deposition rates. Model simulations suggest enhanced wet deposition of sulfate aerosol by precipitation in reduced sea-ice conditions (Mahmood et al., 2018). It is not known whether this enhanced deposition will affect sea-ice melt rates.

\subsection{Cloud scavenging and long-range transport}

As described in Sect. 2, there is a transition in scavenging regimes between the efficient processes that occur with liquid clouds and the comparatively inefficient processes associated with pure ice clouds. However, the community struggles to accurately include such scavenging processes in models (Mahmood et al., 2016). This is important for long-range transport of pollutants from more industrialized southerly locations, and for the input of biomass burning aerosol that is likely to become more prevalent with the warming climate (Marelle et al., 2015; Shindell et al., 2008; H. Wang et al., 2013).

The degree of aerosol scavenging that occurs outside the Arctic relative to that which occurs within it must be better established. For example, transport associated with warm conveyor belt systems is one mechanism that supplies pollutants to the Arctic (Ancellet et al., 2014; Roiger et al., 2011), while cloud formation associated with synoptic uplift in mid-latitudes cleans the air. This has been nicely demonstrated by a close inverse relationship between the accumulated precipitation along back trajectories, a measure of wet scavenging, and $\mathrm{BC}$ levels arriving in the Arctic (Matsui et al., 2011). Deciphering the efficiency of such extra-Arctic processes is one focus of the proposed IMPAACT project (https://pacesproject.org/abstract/introducing-impaact- investigating-pollutant-transport-asia-arctic-and-northamerica, last access: 16 February 2019), which will involve multiple research aircraft and surface-level vessels trying to better understand pollutant levels at their sources and their modifications along these transport pathways. IMPAACT is one effort of PACES which is a broader activity aimed at reducing uncertainties associated with pollution in the Arctic (https://pacesproject.org/about, last access: 16 February 2019). A second example is wet scavenging that occurs as a result of air lifting over Arctic terrain, such as Ellesmere Island and Greenland. In ongoing NETCARE analysis, there is evidence that new particles formed in very clean free tropospheric air masses that had been lifted over Greenland and passed to its north. It is likely that cloud scavenging occurred over Greenland.

A related question is the degree to which oxidation processes modify the overall aerosol composition as a function of residence time in the Arctic. For the measurements described in Sect. 4.4, the increase in the sulfate-to-organic ratio with decreasing altitude in springtime aerosol may in part arise from formation of sulfate as the air mass ages. Validation of this mechanism awaits better $\mathrm{SO}_{2}$ measurements.

\subsection{INPs in the cold seasons and atmospheric impacts}

While aerosol particle removal is exceedingly efficient under summer conditions, the ice nucleation processes in the colder months are much more selective and less well understood, as described in Sect. 5. We sought to understand which aerosol types contain the best ice-nucleating particles. Initial indications from NETCARE measurements are that dust is an important contributor to the INP population (Fig. 14), but that does not rule out the role of primary sea spray particles acting as INPs. A second important question was to what degree coatings of secondary materials, such as sulfates or organics, modify the ice nucleation properties of primary INPs, such as mineral dust. A major challenge is the development of better parameterizations of INPs for use in atmospheric modelling. To that end, work in NETCARE improved ice nucleation parameterizations in the Global Multiscale Environmental Model (GEM-LAM) to determine the effect of pollution on clouds in the Arctic (Keita and Girard, 2016). To simulate pristine clouds, a parameterization of ice nucleation by mineral dust was included, whereas to simulate ice clouds influenced by pollution, a parameterization of ice nucleation by mineral dust coated with sulfuric acid was used. A parameterization was developed as well to test against the 2014 and 2016 CCGS Amundsen INP measurement data. Nevertheless, many details about the ice cloud formation process are still missing from these parameterizations.

Although NETCARE measurements of aerosol deposition fluxes to the snow at Alert were made across a full cold season (see Sect. 4.7), the degree to which this flux occurred via dry or wet deposition was not precisely determined. In particular, it remains to be determined how important ice cloud 
scavenging and settling is as a particle removal process. A long-term, high time resolution aerosol deposition network that separates wet and dry deposition across the Arctic would be highly beneficial in this regard.

\subsection{Aerosol particle mixing state}

Mixing state refers to the uniformity of the distribution of the aerosol chemical components across an array of particles; i.e. are all the particles of the same chemical composition or is their chemical distribution heterogeneous? NETCARE measurements have highlighted how this information is crucial to our understanding of aerosol sources and impacts. In particular, the springtime measurements of $\mathrm{BC}$ aerosol described in Sects. 4.4 and 4.5 showed that within the Arctic haze sampled in spring 2015 , only $3 \%-16 \%$ of the particles contained $\mathrm{BC}$ inclusions and that $\mathrm{BC}$-containing particles had coatings $40-45 \mathrm{~nm}$ in thickness on average (Kodros et al., 2018). The direct radiative forcing that is modelled using these results as constraints is distinctly different from that where it was assumed that the chemical mixing state of the aerosol was uniform (see Sect. 4.5). Likewise, in the summertime measurements from 2014, the single-particle mass spectrometry measurements at low altitudes over open water illustrate that primary and secondary marine aerosol components were externally mixed, thus indicating different formation processes (Fig. 9; Köllner et al., 2017; Willis et al., 2016). More measurements of this type, down to as small a particle size as possible, are crucial for further determining the balance between primary and secondary marine aerosols, to establishing the degrees of coating that exist on mineral dust aerosol that contain INPs, and to assessing the efficiency of cloud scavenging that occurs across different particle types. For example, does the relatively hydrophobic character of $\mathrm{BC}$ inhibit the rate at which it is wet cloud scavenged, and if so, how much hygroscopic coating material must be present to make the particles CCN active?

\subsection{Measurements across the seasons and throughout the atmosphere}

The Arctic springtime has been much more extensively studied than other seasons. This is understandable given the importance of the Arctic haze phenomenon. However, the fall and winter seasons are poorly characterized using intensive campaign approaches, largely because of the operational difficulties in working under cold, dark conditions. Although remote sensing can be used to study transitions between seasons (see Sect. 4.6), it is still important to better understand how transport patterns of pollutants and their deposition rates change seasonally. As well, we know very little about the polar night and the associated formation of ice clouds. The radiative effects of these clouds and their ability to dehydrate the atmosphere on a large scale through extensive light precipitation are important to assess. An exciting movement in this direction is the development of a far infrared radiometer (FIRR) that was flown on the Polar 6 aircraft for the first time within NETCARE (Libois et al., 2016a, b; see Sect. 5.5). By providing improved ice cloud characterization and measurements of atmospheric water vapour, this instrument can be used to improve understanding of the cooling of the atmosphere via infrared emissions in cold polar regions.

The vertical profiles measured as part of NETCARE in both the springtime and summertime provide essential information for comparison to model outputs and provide a necessary complement to the much more extensive sets of measurements from ground-based field campaigns and stations. Additional aircraft campaigns that provide such vertically resolved features are a top priority for future studies. Nevertheless, the continuous measurements at Arctic ground stations remain our most valuable data set to assess long-term trends. There is a significant need to enhance the instrumental capabilities at these stations, for example with key continuous measurements of $\mathrm{SO}_{2}, \mathrm{NH}_{3}$, VOCs, and aerosol composition across all size ranges to further our understanding of many of the issues described above.

Data availability. The NETCARE atmospheric measurements are publicly available through the Government of Canada open data portal (https://open.canada.ca, last access: 16 February 2019, Government of Canada, 2019) and the oceanic measurements are available via the Polar Data Catalogue (https://www.polardata.ca/, last access: 16 February 2019, Canadian Cryospheric Information Network, 2019).

Supplement. The supplement related to this article is available online at: https://doi.org/10.5194/acp-19-1-2019-supplement.

Author contributions. JPDA coordinated and wrote substantial portions of the paper. All other co-authors contributed text and/or reviewed the paper. All co-authors either wrote a first-author paper as part of the NETCARE project or else contributed in a substantive manner to the research conducted in the project or presented in the paper. EG contributed to the INP and ice cloud research of NETCARE but he died before submission. We regard his approval for inclusion of his name on this paper as implicit.

Competing interests. The authors declare that they have no conflict of interest.

Special issue statement. This article is part of the special issue "NETCARE (Network on Aerosols and Climate: Addressing Key Uncertainties in Remote Canadian Environments) (ACP/AMT/BG inter-journal SI)". It is not associated with a conference. 
Acknowledgements. NETCARE was funded by the Natural Sciences and Engineering Research Council (NSERC) of Canada under its Climate Change and Atmospheric Research program, with additional financial and in-kind support from Environment and Climate Change Canada, Fisheries and Oceans Canada, the Alfred Wegener Institute, and the Major Research Project Management Fund at the University of Toronto. Colorado State University researchers were supported by the US Department of Energy's Atmospheric System Research, an Office of Science, Office of Biological and Environmental Research program, under grant no. DE-SC0011780, the US National Science Foundation, Atmospheric Chemistry program, under grant no. AGS-1559607, and by the US National Oceanic and Atmospheric Administration, an Office of Science, Office of Atmospheric Chemistry, Carbon Cycle, and Climate Program, under the cooperative agreement award no. NA17OAR430001. All authors would like to strongly thank: (i) the editors for the NETCARE special issue in Atmospheric Chemistry and Physics, Biogeosciences, and Atmospheric Measurement Techniques for their time and commitment, (ii) members of the NETCARE Scientific Steering Committee, and (iii) other NETCARE collaborators.

This paper is dedicated to Eric Girard, a NETCARE scientist who died 10 July 2018. Eric Girard contributed greatly to the field of Arctic cloud and aerosol microphysics during his research career.

Edited by: Ken Carslaw

Reviewed by: two anonymous referees

\section{References}

Abbatt, J. P. D., Benz, S., Cziczo, D. J., Kanji, Z., Lohmann, U., and Moehler, O.: Solid ammonium sulfate aerosols as ice nuclei: A pathway for cirrus cloud formation, Science, 313, 1770-1773, https://doi.org/10.1126/science.1129726, 2006.

Agrawal, H., Welch, W. A., Miller, J. W., and Cocker, D. R.: Emission measurements from a crude oil tanker at sea, Environ. Sci. Technol., 42, 7098-7103, https://doi.org/10.1021/es703102y, 2008.

Aliabadi, A. A., Staebler, R. M., and Sharma, S.: Air quality monitoring in communities of the Canadian Arctic during the high shipping season with a focus on local and marine pollution, Atmos. Chem. Phys., 15, 2651-2673, https://doi.org/10.5194/acp15-2651-2015, 2015.

Aliabadi, A. A., Staebler, R. M., Liu, M., and Herber, A.: Characterization and Parametrization of Reynolds Stress and Turbulent Heat Flux in the Stably-Stratified Lower Arctic Troposphere Using Aircraft Measurements, Bound.-Lay. Meteorol., 161, 99126, https://doi.org/10.1007/s10546-016-0164-7, 2016 a.

Aliabadi, A. A., Thomas, J. L., Herber, A. B., Staebler, R. M., Leaitch, W. R., Schulz, H., Law, K. S., Marelle, L., Burkart, J., Willis, M. D., Bozem, H., Hoor, P. M., Köllner, F., Schneider, J., Levasseur, M., and Abbatt, J. P. D.: Ship emissions measurement in the Arctic by plume intercepts of the Canadian Coast Guard icebreaker Amundsen from the Polar 6 aircraft platform, Atmos. Chem. Phys., 16, 7899-7916, https://doi.org/10.5194/acp16-7899-2016, 2016b.
AMAP: AMAP Assessment 2013: Arctic Ocean Acidification, Arctic Monitoring and Assessment Programme (AMAP), Oslo, Norway, 2013.

AMAP: AMAP Assessment 2015: Black carbon and ozone as Arctic climate forcers, Arctic Monitoring and Assessment Programme (AMAP), Oslo, Norway, 2015.

AMAP: Snow, Water, Ice and Permafrost. Summary for Policymakers, Arctic Monitoring and Assessment Programme (AMAP), Oslo, Norway, 2017.

Ancellet, G., Pelon, J., Blanchard, Y., Quennehen, B., Bazureau, A., Law, K. S., and Schwarzenboeck, A.: Transport of aerosol to the Arctic: analysis of CALIOP and French aircraft data during the spring 2008 POLARCAT campaign, Atmos. Chem. Phys., 14, 8235-8254, https://doi.org/10.5194/acp-14-8235-2014, 2014.

Andrews, E., Ogren, J. A., Bonasoni, P., Marinoni, A., Cuevas, E., Rodriguez, S., Sun, J. Y., Jaffe, D. A., Fischer, E. V., Baltensperger, U., Weingartner, E., Coen, M. C., Sharma, S., Macdonald, A. M., Leaitch, W. R., Lin, N.-H., Laj, P., Arsov, T., Kalapov, I., Jefferson, A., and Sheridan, P.: Climatology of aerosol radiative properties in the free troposphere, Atmos. Res., 102, 365-393, https://doi.org/10.1016/j.atmosres.2011.08.017, 2011.

Archer, S. D., Kimmance, S. A., Stephens, J. A., Hopkins, F. E., Bellerby, R. G. J., Schulz, K. G., Piontek, J., and Engel, A.: Contrasting responses of DMS and DMSP to ocean acidification in Arctic waters, Biogeosciences, 10, 1893-1908, https://doi.org/10.5194/bg-10-1893-2013, 2013.

Arrigo, K. R.: Sea Ice Ecosystems, Annu. Rev. Mar. Sci., 6, 439467, https://doi.org/10.1146/annurev-marine-010213-135103, 2014.

Arrigo, K. R. and van Dijken, G. L.: Continued increases in Arctic Ocean primary production, Prog. Oceanogr., 136, 60-70, https://doi.org/10.1016/j.pocean.2015.05.002, 2015.

Barrie, L. A.: Arctic air pollution: An overview of current knowledge, Atmos. Environ., 20, 643-663, https://doi.org/10.1016/0004-6981(86)90180-0, 1986.

Barrie, L. A. and Hoff, R. M.: Five years of air chemistry observations in the Canadian Arctic, Atmos. Environ., 19, 1995-2010, https://doi.org/10.1016/0004-6981(85)90108-8, 1985.

Becagli, S., Lazzara, L., Marchese, C., Dayan, U., Ascanius, S. E., Cacciani, M., Caiazzo, L., Di Biagio, C., Di Iorio, T., di Sarra, A., Eriksen, P., Fani, F., Giardi, F., Meloni, D., Muscari, G., Pace, G., Severi, M., Traversi, R., and Udisti, R.: Relationships linking primary production, sea ice melting, and biogenic aerosol in the Arctic, Atmos. Environ., 136, 1-15, https://doi.org/10.1016/j.atmosenv.2016.04.002, 2016.

Bigg, E. K.: Comparison of aerosol at four baseline atmospheric monitoring stations, J. Appl. Meteorol., 19, 521-533, 1980.

Bigg, E. K. and Leck, C.: The composition of fragments of bubbles bursting at the ocean surface, J. Geophys. Res.-Atmos., 113, D11209, https://doi.org/10.1029/2007JD009078, 2008.

Blanchet, J.-P. and Girard, E.: Arctic "greenhouse effect", Nature, 371, 383, https://doi.org/10.1038/371383a0, 1994.

Blanchet, J.-P. and List, R.: Estimation of optical properties of arctic haze using a numerical model, Atmos.-Ocean, 21, 444-465, https://doi.org/10.1080/07055900.1983.9649179, 1983.

Bond, T. C., Doherty, S. J., Fahey, D. W., Forster, P. M., Berntsen, T., DeAngelo, B. J., Flanner, M. G., Ghan, S., Kärcher, B., Koch, D., Kinne, S., Kondo, Y., Quinn, P. K., Sarofim, M. C., Schultz, 
M. G., Schulz, M., Venkataraman, C., Zhang, H., Zhang, S., Bellouin, N., Guttikunda, S. K., Hopke, P. K., Jacobson, M. Z., Kaiser, J. W., Klimont, Z., Lohmann, U., Schwarz, J. P., Shindell, D., Storelvmo, T., Warren, S. G., and Zender, C. S.: Bounding the role of black carbon in the climate system: A scientific assessment, J. Geophys. Res.-Atmos., 118, 5380-5552, https://doi.org/10.1002/jgrd.50171, 2013.

Bopp, L., Carslaw, K. S., Cziczo, D. J., and Russell, L. M. (Eds.): NETCARE (Network on Aerosols and Climate: Addressing Key Uncertainties in Remote Canadian Environments) (ACP/AMT/BG inter-journal SI), Atmos. Chem. Phys., Atmos. Meas. Tech., Biogeosciences, https://www.atmos-chem-phys. net/special_issue835.html, 2014.

Bourgeois, Q. and Bey, I.: Pollution transport efficiency toward the Arctic: Sensitivity to aerosol scavenging and source regions, J. Geophys. Res.-Atmos., 116, D08213, https://doi.org/10.1029/2010JD015096, 2011.

Bozem, H., Hoor, P., Kunkel, D., Köllner, F., Schneider, J., Herber, A., Schulz, H., Leaitch, W. R., Aliabadi, A. A., Willis, M. D., Burkart, J., and Abbatt, J. P. D.: Characterization of Transport Regimes and the Polar Dome during Arctic Spring and Summer using in-situ Aircraft Measurements, Atmos. Chem. Phys. Discuss., https://doi.org/10.5194/acp-2019-70, in review, 2019.

Breider, T. J., Mickley, L. J., Jacob, D. J., Ge, C., Wang, J., Sulprizio Payer, M., Croft, B., Ridley, D. A., McConnell, J. R., Sharma, S., Husain, L., Dutkiewicz, V. A., Eleftheriadis, K., Skov, H., and Hopke, P. K.: Multidecadal trends in aerosol radiative forcing over the Arctic: Contribution of changes in anthropogenic aerosol to Arctic warming since 1980, J. Geophys. Res.-Atmos., 122, 3573-3594, https://doi.org/10.1002/2016JD025321, 2017.

Brock, C. A., Radke, L. F., Lyons, J. H., and Hobbs, P. V.: Arctic hazes in summer over Greenland and the North American Arctic. I: Incidence and origins, J. Atmos. Chem., 9, 129-148, https://doi.org/10.1007/BF00052828, 1989.

Brock, C. A., Cozic, J., Bahreini, R., Froyd, K. D., Middlebrook, A. M., McComiskey, A., Brioude, J., Cooper, O. R., Stohl, A., Aikin, K. C., de Gouw, J. A., Fahey, D. W., Ferrare, R. A., Gao, R.-S., Gore, W., Holloway, J. S., Hübler, G., Jefferson, A., Lack, D. A., Lance, S., Moore, R. H., Murphy, D. M., Nenes, A., Novelli, P. C., Nowak, J. B., Ogren, J. A., Peischl, J., Pierce, R. B., Pilewskie, P., Quinn, P. K., Ryerson, T. B., Schmidt, K. S., Schwarz, J. P., Sodemann, H., Spackman, J. R., Stark, H., Thomson, D. S., Thornberry, T., Veres, P., Watts, L. A., Warneke, C., and Wollny, A. G.: Characteristics, sources, and transport of aerosols measured in spring 2008 during the aerosol, radiation, and cloud processes affecting Arctic Climate (ARCPAC) Project, Atmos. Chem. Phys., 11, 24232453, https://doi.org/10.5194/acp-11-2423-2011, 2011.

Brockmann, U. H., Huhnerfuss, H., Kattner, G., Broecker, H.-C., and Hentzschel, G.: Artificial surface films in the sea area near Sylt, Limnol. Oceanogr., 27, 1050-1058, https://doi.org/10.4319/lo.1982.27.6.1050, 1982.

Browse, J., Carslaw, K. S., Arnold, S. R., Pringle, K., and Boucher, O.: The scavenging processes controlling the seasonal cycle in Arctic sulphate and black carbon aerosol, Atmos. Chem. Phys., 12, 6775-6798, https://doi.org/10.5194/acp12-6775-2012, 2012.

Browse, J., Carslaw, K. S., Mann, G. W., Birch, C. E., Arnold, S. R., and Leck, C.: The complex response of Arctic aerosol to sea-ice retreat, Atmos. Chem. Phys., 14, 7543-7557, https://doi.org/10.5194/acp-14-7543-2014, 2014.

Burkart, J., Hodshire, A. L., Mungall, E. L., Pierce, J. R., Collins, D. B., Ladino, L. A., Lee, A. K. Y., Irish, V., Wentzell, J. J. B., Liggio, J., Papakyriakou, T., Murphy, J., and Abbatt, J.: Organic condensation and particle growth to $\mathrm{CCN}$ sizes in the summertime marine Arctic is driven by materials more semivolatile than at continental sites, Geophys. Res. Lett., 44, 10725-10734, https://doi.org/10.1002/2017GL075671, 2017a.

Burkart, J., Willis, M. D., Bozem, H., Thomas, J. L., Law, K., Hoor, P., Aliabadi, A. A., Köllner, F., Schneider, J., Herber, A., Abbatt, J. P. D., and Leaitch, W. R.: Summertime observations of elevated levels of ultrafine particles in the high Arctic marine boundary layer, Atmos. Chem. Phys., 17, 5515-5535, https://doi.org/10.5194/acp-17-5515-2017, 2017 b.

Burrows, S. M., Hoose, C., Pöschl, U., and Lawrence, M. G.: Ice nuclei in marine air: biogenic particles or dust?, Atmos. Chem. Phys., 13, 245-267, https://doi.org/10.5194/acp-13-2452013, 2013.

Canadian Cryospheric Information Network, Polar Data Catalogue, https://www.polardata.ca/, last access: 16 February 2019.

Cantrell, W. and Heymsfield, A.: Production of ice in tropospheric clouds: a review, B. Am. Meteorol. Soc., 86, 795-808, https://doi.org/10.1175/BAMS-86-6-795, 2005.

Cappa, C. D., Williams, E. J., Lack, D. A., Buffaloe, G. M., Coffman, D., Hayden, K. L., Herndon, S. C., Lerner, B. M., Li, S.-M., Massoli, P., McLaren, R., Nuaaman, I., Onasch, T. B., and Quinn, P. K.: A case study into the measurement of ship emissions from plume intercepts of the NOAA ship Miller Freeman, Atmos. Chem. Phys., 14, 1337-1352, https://doi.org/10.5194/acp14-1337-2014, 2014.

Carslaw, K. S., Lee, L. A., Reddington, C. L., Pringle, K. J., Rap, A., Forster, P. M., Mann, G. W., Spracklen, D. V., Woodhouse, M. T., Regayre, L. A., and Pierce, J. R.: Large contribution of natural aerosols to uncertainty in indirect forcing, Nature, 503, 67-71, https://doi.org/10.1038/nature12674, 2013.

Chang, R. Y.-W., Leck, C., Graus, M., Müller, M., Paatero, J., Burkhart, J. F., Stohl, A., Orr, L. H., Hayden, K., Li, S.-M., Hansel, A., Tjernström, M., Leaitch, W. R., and Abbatt, J. P. D.: Aerosol composition and sources in the central Arctic Ocean during ASCOS, Atmos. Chem. Phys., 11, 10619-10636, https://doi.org/10.5194/acp-11-10619-2011, 2011a.

Chang, R. Y.-W., Sjostedt, S. J., Pierce, J. R., Papakyriakou, T. N., Scarratt, M. G., Michaud, S., Levasseur, M., Leaitch, W. R., and Abbatt, J. P. D.: Relating atmospheric and oceanic DMS levels to particle nucleation events in the Canadian Arctic, J. Geophys. Res.-Atmos., 116, D00S03, https://doi.org/10.1029/2011jd015926, 2011b.

Charlson, R., Lovelock, J., Andreae, M., and Warren, S.: Oceanic Phytoplankton, Atmospheric Sulfur, Cloud Albedo and Climate, Nature, 326, 655-661, https://doi.org/10.1038/326655a0, 1987.

Chaubey, J. P., Boyer, M., Collins, D., Mungall, E. L., Abbatt, J. P. D., and Chang, R. Y.-W.: Cloud condensation nuclei over the Canadian Arctic during summer, in preparation, 2019.

Clarke, A. D. and Noone, K. J.: Soot in the Arctic snowpack: a cause for perturbations in radiative transfer, Atmos. Environ., 19, 2045-2053, https://doi.org/10.1016/0004-6981(85)90113-1, 1985. 
Collins, D. B., Burkart, J., Chang, R. Y.-W., Lizotte, M., BoivinRioux, A., Blais, M., Mungall, E. L., Boyer, M., Irish, V. E., Massé, G., Kunkel, D., Tremblay, J.-É., Papakyriakou, T., Bertram, A. K., Bozem, H., Gosselin, M., Levasseur, M., and Abbatt, J. P. D.: Frequent ultrafine particle formation and growth in Canadian Arctic marine and coastal environments, Atmos. Chem. Phys., 17, 13119-13138, https://doi.org/10.5194/acp-1713119-2017, 2017.

Coluzza, I., Creamean, J., Rossi, M. J., Wex, H., Alpert, P. A., Bianco, V., Boose, Y., Dellago, C., Felgitsch, L., FröhlichNowoisky, J., Herrmann, H., Jungblut, S., Kanji, Z. A., Menzl, G., Moffett, B., Moritz, C., Mutzel, A., Pöschl, U., Schauperl, M., Scheel, J., Stopelli, E., Stratmann, F., Grothe, H., and Schmale, D. G.: Perspectives on the Future of Ice Nucleation Research: Research Needs and Unanswered Questions Identified from Two International Workshops, Atmosphere, 8, 138, https://doi.org/10.3390/atmos8080138, 2017.

Comiso, J. C.: Large decadal decline of the Arctic multiyear ice cover, J. Climate, 25, 1176-1193, https://doi.org/10.1175/JCLID-11-00113.1, 2011.

Corbett, J. J., Lack, D. A., Winebrake, J. J., Harder, S., Silberman, J. A., and Gold, M.: Arctic shipping emissions inventories and future scenarios, Atmos. Chem. Phys., 10, 9689-9704, https://doi.org/10.5194/acp-10-9689-2010, 2010.

Croft, B., Wentworth, G. R., Martin, R. V., Leaitch, W. R., Murphy, J. G., Murphy, B. N., Kodros, J. K., Abbatt, J. P. D., and Pierce, J. R.: Contribution of Arctic seabird-colony ammonia to atmospheric particles and cloud-albedo radiative effect, Nat. Commun., 7, 13444, https://doi.org/10.1038/ncomms13444, 2016a.

Croft, B., Martin, R. V., Leaitch, W. R., Tunved, P., Breider, T. J., D'Andrea, S. D., and Pierce, J. R.: Processes controlling the annual cycle of Arctic aerosol number and size distributions, Atmos. Chem. Phys., 16, 3665-3682, https://doi.org/10.5194/acp16-3665-2016, $2016 \mathrm{~b}$.

Croft, B., Martin, R. V., Leaitch, W. R., Burkart, J., Chang, R. Y.-W., Collins, D. B., Hayes, P. L., Hodshire, A. L., Huang, L., Kodros, J. K., Moravek, A., Mungall, E. L., Murphy, J. G., Sharma, S., Tremblay, S., Wentworth, G. R., Willis, M. D., Abbatt, J. P. D., and Pierce, J. R.: Arctic marine secondary organic aerosol contributes significantly to summertime particle size distributions in the Canadian Arctic Archipelago, Atmos. Chem. Phys. Discuss., https://doi.org/10.5194/acp-2018-895, in review, 2018.

Cunliffe, M., Engel, A., Frka, S., Gašparović, B., Guitart, C., Murrell, J. C., Salter, M., Stolle, C., Upstill-Goddard, R., and Wurl, O.: Sea surface microlayers: A unified physicochemical and biological perspective of the air-ocean interface, Prog. Oceanogr., 109, 104-116, https://doi.org/10.1016/j.pocean.2012.08.004, 2013.

Curry, J. A. and Herman, G. F.: Infrared Radiative Properties of Summertime Arctic Stratus Clouds, J. Clim. Appl. Meteorol., 24, 525-538, https://doi.org/10.1175/15200450(1985)024<0525:IRPOSA>2.0.CO;2, 1985.

Dall'Osto, M., Beddows, D. C. S., Tunved, P., Krejci, R., Ström, J., Hansson, H.-C., Yoon, Y. J., Park, K.-T., Becagli, S., Udisti, R., Onasch, T., O’Dowd, C. D., Simó, R., and Harrison, R. M.: Arctic sea ice melt leads to atmospheric new particle formation, Sci. Rep., 7, 3318, https://doi.org/10.1038/s41598-017-03328-1, 2017.
DeMott, P. J., Prenni, A. J., Liu, X., Kreidenweis, S. M., Petters, M. D., Twohy, C. H., Richardson, M. S., Eidhammer, T., and Rogers, D. C.: Predicting global atmospheric ice nuclei distributions and their impacts on climate, P. Natl. Acad. Sci. USA, 107, 1121711222, https://doi.org/10.1073/pnas.0910818107, 2010.

DeMott, P. J., Hill, T. C. J., McCluskey, C. S., Prather, K. A., Collins, D. B., Sullivan, R. C., Ruppel, M. J., Mason, R. H., Irish, V. E., Lee, T., Hwang, C. Y., Rhee, T. S., Snider, J. R., McMeeking, G. R., Dhaniyala, S., Lewis, E. R., Wentzell, J. J. B., Abbatt, J., Lee, C., Sultana, C. M., Ault, A. P., Axson, J. L., Martinez, M. D., Venero, I., Santos-Figueroa, G., Stokes, M. D., Deane, G. B., Mayol-Bracero, O. L., Grassian, V. H., Bertram, T. H., Bertram, A. K., Moffett, B. F., and Franc, G. D.: Sea spray aerosol as a unique source of ice nucleating particles, P. Natl. Acad. Sci. USA, 113, 5797-5803, https://doi.org/10.1073/pnas.1514034112, 2016.

Doherty, S. J., Warren, S. G., Grenfell, T. C., Clarke, A. D., and Brandt, R. E.: Light-absorbing impurities in Arctic snow, Atmos. Chem. Phys., 10, 11647-11680, https://doi.org/10.5194/acp-1011647-2010, 2010.

Doherty, S. J., Dang, C., Hegg, D. A., Zhang, R., and Warren, S. G.: Black carbon and other light-absorbing particles in snow of central North America, J. Geophys. Res.-Atmos., 119, 1280712831, https://doi.org/10.1002/2014JD022350, 2014.

Dumont, M., Brun, E., Picard, G., Michou, M., Libois, Q., Petit, J.-R., Geyer, M., Morin, S., and Josse, B.: Contribution of light-absorbing impurities in snow to Greenland's darkening since 2009, Nat. Geosci., 7, 509-512, https://doi.org/10.1038/ngeo2180, 2014.

Duncan, B. N. and Bey, I.: A modeling study of the export pathways of pollution from Europe: Seasonal and interannual variations (1987-1997), J. Geophys. Res.-Atmos., 109, D08301, https://doi.org/10.1029/2003JD004079, 2004.

Earle, M., E., Liu, X., Walter Strapp, J., Zelenyuk, A., Imre, D., Mcfarquhar, G., Shantz, N., and Richard Leaitch, W.: Factors influencing the microphysics and radiative properties of liquid-dominated Arctic clouds: Insight from observations of aerosol and clouds during ISDAC, J. Geophys. Res.-Atmos., 116, D00T09, https://doi.org/10.1029/2011JD015887, 2011.

Eastwood, M. L., Cremel, S., Wheeler, M., Murray, B. J., Girard, E., and Bertram, A. K.: Effects of sulfuric acid and ammonium sulfate coatings on the ice nucleation properties of kaolinite particles, Geophys. Res. Lett., 36, L02811, https://doi.org/10.1029/2008GL035997, 2009.

Eckhardt, S., Stohl, A., Beirle, S., Spichtinger, N., James, P., Forster, C., Junker, C., Wagner, T., Platt, U., and Jennings, S. G.: The North Atlantic Oscillation controls air pollution transport to the Arctic, Atmos. Chem. Phys., 3, 1769-1778, https://doi.org/10.5194/acp-3-1769-2003, 2003.

Eckhardt, S., Quennehen, B., Olivié, D. J. L., Berntsen, T. K., Cherian, R., Christensen, J. H., Collins, W., Crepinsek, S., Daskalakis, N., Flanner, M., Herber, A., Heyes, C., Hodnebrog, Ø., Huang, L., Kanakidou, M., Klimont, Z., Langner, J., Law, K. S., Lund, M. T., Mahmood, R., Massling, A., Myriokefalitakis, S., Nielsen, I. E., Nøjgaard, J. K., Quaas, J., Quinn, P. K., Raut, J.-C., Rumbold, S. T., Schulz, M., Sharma, S., Skeie, R. B., Skov, H., Uttal, T., von Salzen, K., and Stohl, A.: Current model capabilities for simulating black carbon and sulfate concentrations in the Arctic atmosphere: a multi-model evaluation using a 
comprehensive measurement data set, Atmos. Chem. Phys., 15, 9413-9433, https://doi.org/10.5194/acp-15-9413-2015, 2015.

Elliott, S., Deal, C., Humphries, G., Hunke, E., Jeffery, N., Jin, M., Levasseur, M., and Stefels, J.: Pan-Arctic simulation of coupled nutrient-sulfur cycling due to sea ice biology: Preliminary results, J. Geophys. Res.-Biogeo., 117, G01016, https://doi.org/10.1029/2011JG001649, 2012.

Engel, A., Bange, H. W., Cunliffe, M., Burrows, S. M., Friedrichs, G., Galgani, L., Herrmann, H., Hertkorn, N., Johnson, M., Liss, P. S., Quinn, P. K., Schartau, M., Soloviev, A., Stolle, C., Upstill-Goddard, R. C., van Pinxteren, M., and Zäncker, B.: The ocean's vital skin: toward an integrated understanding of the sea surface microlayer, Front. Mar. Sci., 4, 165, https://doi.org/10.3389/fmars.2017.00165, 2017.

Fisher, J. A., Jacob, D. J., Wang, Q., Bahreini, R., Carouge, C. C., Cubison, M. J., Dibb, J. E., Diehl, T., Jimenez, J. L., Leibensperger, E. M., Lu, Z., Meinders, M. B. J., Pye, H. O. T., Quinn, P. K., Sharma, S., Streets, D. G., van Donkelaar, A., and Yantosca, R. M.: Sources, distribution, and acidity of sulfate-ammonium aerosol in the Arctic in winter-spring, Atmos. Environ., 45, 7301-7318, https://doi.org/10.1016/j.atmosenv.2011.08.030, 2011.

Flanner, M. G., Zender, C. S., Randerson, J. T., and Rasch, P. J.: Present-day climate forcing and response from black carbon in snow, J. Geophys. Res.-Atmos., 112, D11202, https://doi.org/10.1029/2006JD008003, 2007.

Forsström, S., Isaksson, E., Skeie, R. B., Ström, J., Pedersen, C. A., Hudson, S. R., Berntsen, T. K., Lihavainen, H., Godtliebsen, F., and Gerland, S.: Elemental carbon measurements in European Arctic snow packs, J. Geophys. Res.-Atmos., 118, 13614-13627, https://doi.org/10.1002/2013JD019886, 2013.

Frew, N. M., Bock, E. J., Schimpf, U., Hara, T., Haußecker, H., Edson, J. B., McGillis, W. R., Nelson, R. K., McKenna, S. P., Uz, B. M., and Jähne, B.: Air-sea gas transfer: Its dependence on wind stress, small-scale roughness, and surface films, J. Geophys. Res.-Oceans, 109, C08S17, https://doi.org/10.1029/2003JC002131, 2004.

Frossard, A. A., Shaw, P. M., Russell, L. M., Kroll, J. H., Canagaratna, M. R., Worsnop, D. R., Quinn, P. K., and Bates, T. S.: Springtime Arctic haze contributions of submicron organic particles from European and Asian combustion sources, J. Geophys. Res.-Atmos., 116, D05205, https://doi.org/10.1029/2010jd015178, 2011.

Frossard, A. A., Russell, L. M., Massoli, P., Bates, T. S., and Quinn, P. K.: Side-by-side comparison of four techniques explains the apparent differences in the organic composition of generated and ambient marine aerosol particles, Aerosol Sci. Tech., 48, 5-10, https://doi.org/10.1080/02786826.2013.879979, 2014.

Fyfe, J. C., Salzen, K. von, Gillett, N. P., Arora, V. K., Flato, G. M., and McConnell, J. R.: One hundred years of Arctic surface temperature variation due to anthropogenic influence, Sci. Rep., 3, 2645, https://doi.org/10.1038/srep02645, 2013.

Gabric, A., Matrai, P., Jones, G., and Middleton, J.: The nexus between sea ice and polar emissions of marine biogenic aerosols, B. Am. Meteorol. Soc., 99, 61-81, https://doi.org/10.1175/BAMSD-16-0254.1, 2017.

Galí, M. and Simó, R.: Occurrence and cycling of dimethylated sulfur compounds in the Arctic during summer receding of the ice edge, Mar. Chem., 122, 105-117, https://doi.org/10.1016/j.marchem.2010.07.003, 2010.

Galí, M., Levasseur, M., Devred, E., Simó, R., and Babin, M.: Seasurface dimethylsulfide (DMS) concentration from satellite data at global and regional scales, Biogeosciences, 15, 3497-3519, https://doi.org/10.5194/bg-15-3497-2018, 2018.

Galí, M., Devred, E., Babin, M., and Maurice, L.: Increasing dimethylsulphide emission in a changing Arctic Ocean, in preparation, 2019.

Garbe, C. S., Rutgersson, A., Boutin, J., Leeuw, G. de, Delille, B., Fairall, C. W., Gruber, N., Hare, J., Ho, D. T., Johnson, M. T., Nightingale, P. D., Pettersson, H., Piskozub, J., Sahlée, E., Tsai, W., Ward, B., Woolf, D. K., and Zappa, C. J.: Transfer across the air-sea interface, in: Ocean-Atmosphere Interactions of Gases and Particles, Springer, Berlin, Heidelberg, 55-112, https://doi.org/10.1007/978-3-642-25643-1_2, 2014.

Garrett, T. J. and Zhao, C.: Increased Arctic cloud longwave emissivity associated with pollution from mid-latitudes, Nature, 440, 787-789, https://doi.org/10.1038/nature04636, 2006.

Garrett, T. J., Maestas, M. M., Krueger, S. K., and Schmidt, C. T.: Acceleration by aerosol of a radiative-thermodynamic cloud feedback influencing Arctic surface warming, Geophys. Res. Lett., 36, L19804, https://doi.org/10.1029/2009GL040195, 2009.

Garrett, T. J., Zhao, C., and Novelli, P.: Assessing the relative contributions of transport efficiency and scavenging to seasonal variability in Arctic aerosol, Tellus B, 62, 190-196, https://doi.org/10.1111/j.1600-0889.2010.00453.x, 2010.

Ghahremaninezhad, R., Norman, A.-L., Abbatt, J. P. D., Levasseur, M., and Thomas, J. L.: Biogenic, anthropogenic and sea salt sulfate size-segregated aerosols in the Arctic summer, Atmos. Chem. Phys., 16, 5191-5202, https://doi.org/10.5194/acp16-5191-2016, 2016.

Ghahremaninezhad, R., Norman, A.-L., Croft, B., Martin, R. V., Pierce, J. R., Burkart, J., Rempillo, O., Bozem, H., Kunkel, D., Thomas, J. L., Aliabadi, A. A., Wentworth, G. R., Levasseur, M., Staebler, R. M., Sharma, S., and Leaitch, W. R.: Boundary layer and free-tropospheric dimethyl sulfide in the Arctic spring and summer, Atmos. Chem. Phys., 17, 8757-8770, https://doi.org/10.5194/acp-17-8757-2017, 2017.

Gong, S. L., Zhao, T. L., Sharma, S., Toom-Sauntry, D., Lavoué, D., Zhang, X. B., Leaitch, W. R., and Barrie, L. A.: Identification of trends and interannual variability of sulfate and black carbon in the Canadian High Arctic: 1981-2007, J. Geophys. Res., 115, D07305, doi.org/10.1029/2009JD012943, 2010.

Gourdal, M., Lizotte, M., Massé, G., Gosselin, M., Poulin, M., Scarratt, M., Charette, J., and Levasseur, M.: Dimethyl sulfide dynamics in first-year sea ice melt ponds in the Canadian Arctic Archipelago, Biogeosciences, 15, 3169-3188, https://doi.org/10.5194/bg-15-3169-2018, 2018.

Government of Canada: Open Government Website, https://open. canada.ca, last access: 16 February 2019.

Gradinger, R.: Sea-ice algae: Major contributors to primary production and algal biomass in the Chukchi and Beaufort Seas during May/June 2002, Deep-Sea Res. Pt. II, 56, 1201-1212, https://doi.org/10.1016/j.dsr2.2008.10.016, 2009.

Greenaway, K.: Experiences with Arctic flying weather, Canadian Branch Royal. Met. Soc., 1, available at: http://cmosarchives.ca/ RMS/r0109.pdf (last access: 16 February 2019), 1950. 
Gregory, J. M., Stott, P. A., Cresswell, D. J., Rayner, N. A., Gordon, C., and Sexton, D. M. H.: Recent and future changes in Arctic sea ice simulated by the HadCM3 AOGCM, Geophys. Res. Lett., 29, 28-1-28-4, https://doi.org/10.1029/2001GL014575, 2002.

Grenier, P. and Blanchet, J. P.: Investigation of the sulphateinduced freezing inhibition effect from CloudSat and CALIPSO measurements, J. Geophys. Res.-Atmos., 115, D22205, https://doi.org/10.1029/2010JD013905, 2010.

Grenier, P., Blanchet, J. P., and Rodrigo, M.: Study of polar thin ice clouds and aerosols seen by CloudSat and CALIPSO during midwinter 2007, J. Geophys. Res.-Atmos., 114, D09201, https://doi.org/10.1029/2008JD010927, 2009.

Hansen, J. and Nazarenko, L.: Soot climate forcing via snow and ice albedos, P. Natl. Acad. Sci. USA, 101, 423-428, https://doi.org/10.1073/pnas.2237157100, 2004.

Hayashida, H.: Modelling sea-ice and oceanic dimethylsulfide production and emissions in the Arctic, $\mathrm{PhD}$ thesis, University of Victoria, Victoria, BC, Canada, available at: http://dspace.library. uvic.ca/handle/1828/10486 (last access: 16 February 2019), 2018

Hayashida, H., Steiner, N., Monahan, A., Galindo, V., Lizotte, M., and Levasseur, M.: Implications of sea-ice biogeochemistry for oceanic production and emissions of dimethyl sulfide in the Arctic, Biogeosciences, 14, 3129-3155, https://doi.org/10.5194/bg14-3129-2017, 2017.

Hayashida, H., Christian, J. R., Holdsworth, A. M., Hu, X., Monahan, A. H., Mortenson, E., Myers, P. G., Riche, O. G. J., Sou, T., and Steiner, N. S.: CSIB v1: a sea-ice biogeochemical model for the NEMO community ocean modelling framework, Geosci. Model Dev. Discuss., https://doi.org/10.5194/gmd-2018-191, in review, 2018.

Hegg, D. A. and Baker, M. B.: Nucleation in the atmosphere, Rep. Prog. Phys., 72, 056801, https://doi.org/10.1088/00344885/72/5/056801, 2009.

Heidam, N. Z., Wåhlin, P., and Christensen, J. H.: Tropospheric gases and aerosols in Northeast Greenland, J. Atmos. Sci., 56, 261-278, https://doi.org/10.1175/15200469(1999)056<0261:TGAAIN>2.0.CO;2, 1999.

Heintzenberg, J.: Particle size distribution and optical properties of Arctic haze, Tellus, 32, 251-260, https://doi.org/10.3402/tellusa.v32i3.10580, 1980.

Herber, A., Dethloff, K., Haas, C., Steinhage, D., Strapp, J. W., Bottenheim, J., McElroy, T., and Yamanouchi, T.: POLAR 5 - a new research aircraft for improved access to the Arctic, International Symposium on Arctic Research - One (ISAR-1), Drastic Change under the Global Warming, Extended Abstract, 54-57, 2008.

Hesaraki, S., O’Neill, N. T., Lesins, G., Saha, A., Martin, R. V., Fioletov, V. E., Baibakov, K., and Abboud, I.: Comparisons of a chemical transport model with a four-year (April to September) analysis of fine- and coarse-mode aerosol optical depth retrievals over the Canadian Arctic, Atmos.-Ocean, 55, 213-229, https://doi.org/10.1080/07055900.2017.1356263, 2017.

Hirdman, D., Burkhart, J. F., Sodemann, H., Eckhardt, S., Jefferson, A., Quinn, P. K., Sharma, S., Ström, J., and Stohl, A.: Long-term trends of black carbon and sulphate aerosol in the Arctic: changes in atmospheric transport and source region emissions, Atmos. Chem. Phys., 10, 9351-9368, https://doi.org/10.5194/acp-109351-2010, 2010.
Holland, M. M., Bitz, C. M., and Tremblay, B.: Future abrupt reductions in the summer Arctic sea ice, Geophys. Res. Lett., 33, L23503, https://doi.org/10.1029/2006GL028024, 2006.

Holmgren, B., Shaw, G., and Weller, G.: Turbidity in the Arctic atmosphere, AIDJEX Bulletin, 27, 135-148, 1974.

Hopkins, F. E., Nightingale, P. D., Stephens, J. A., Moore, C. M., Richier, S., Cripps, G. L., and Archer, S. D.: Dimethylsulfide (DMS) production in polar oceans may be resilient to ocean acidification, Biogeosciences Discuss., https://doi.org/10.5194/bg2018-55, in review, 2018.

Hoppe, C. J. M., Wolf, K. K. E., Schuback, N., Tortell, P. D., and Rost, B.: Compensation of ocean acidification effects in Arctic phytoplankton assemblages, Nat. Clim. Change, 8, 529-533, https://doi.org/10.1038/s41558-018-0142-9, 2018.

Hoppel, W. A., Fitzgerald, J. W., and Larson, R. E.: Aerosol size distributions in air masses advecting off the east coast of the United States, J. Geophys. Res.-Atmos., 90, 2365-2379, https://doi.org/10.1029/JD090iD01p02365, 1985.

Huang, J. and Jaeglé, L.: Wintertime enhancements of sea salt aerosol in polar regions consistent with a sea ice source from blowing snow, Atmos. Chem. Phys., 17, 3699-3712, https://doi.org/10.5194/acp-17-3699-2017, 2017.

Huang, L., Gong, S. L., Jia, C. Q., and Lavoué, D.: Relative contributions of anthropogenic emissions to black carbon aerosol in the Arctic, J. Geophys. Res., 115, D19208, https://doi.org/10.1029/2009JD013592, 2010.

Hussherr, R., Levasseur, M., Lizotte, M., Tremblay, J.-É., Mol, J., Thomas, H., Gosselin, M., Starr, M., Miller, L. A., Jarniková, T., Schuback, N., and Mucci, A.: Impact of ocean acidification on Arctic phytoplankton blooms and dimethyl sulfide concentration under simulated ice-free and under-ice conditions, Biogeosciences, 14, 2407-2427, https://doi.org/10.5194/bg-142407-2017, 2017.

Ikeda, K., Tanimoto, H., Sugita, T., Akiyoshi, H., Kanaya, Y., Zhu, C., and Taketani, F.: Tagged tracer simulations of black carbon in the Arctic: transport, source contributions, and budget, Atmos. Chem. Phys., 17, 10515-10533, https://doi.org/10.5194/acp-1710515-2017, 2017.

IPCC: Climate Change 2013: The Physical Science Basis, Contribution of Working Group 1 to the Fifth Assessment Report of the Intergovernmental Panel on Climate Change, edited by: Stocker, T. F., Qin, D., Plattner, G.-K., Tignor, M., Allen, S. K., Boschung, J., Nauels, A., Xia, Y., Bex, V., and Midgley, P. M., Cambridge University Press, Cambridge, UK and New York, USA, 2013.

Irish, V. E., Elizondo, P., Chen, J., Chou, C., Charette, J., Lizotte, M., Ladino, L. A., Wilson, T. W., Gosselin, M., Murray, B. J., Polishchuk, E., Abbatt, J. P. D., Miller, L. A., and Bertram, A. K.: Ice-nucleating particles in Canadian Arctic sea-surface microlayer and bulk seawater, Atmos. Chem. Phys., 17, 10583-10595, https://doi.org/10.5194/acp-17-10583-2017, 2017.

Irish, V. E., Hanna, S., Xi, Y., Boyer, M., Polishchuk, E., Chen, J., Abbatt, J. P. D., Gosselin, M., Chang, R., Miller, L., and Bertram, A. K.: Revisiting properties and concentrations of ice nucleating particles in the sea surface microlayer and bulk seawater in the Canadian Arctic during summer, Atmos. Chem. Phys. Discuss., https://doi.org/10.5194/acp-2018-641, in review, 2018.

Irish, V. E., Hanna, S. J., Willis, M. D., China, S., Thomas, J. L., Wentzell, J. J. B., Cirisan, A., Si, M., Leaitch, W. R., Murphy, J. G., Abbatt, J. P. D., Laskin, A., Girard, E., and Bertram, A. 
K.: Ice nucleating particles in the marine boundary layer in the Canadian Arctic during summer 2014, Atmos. Chem. Phys., 19, 1027-1039, https://doi.org/10.5194/acp-19-1027-2019, 2019.

Ito, A. and Kawamiya, M.: Potential impact of ocean ecosystem changes due to global warming on marine organic carbon aerosols, Global Biogeochem. Cy., 24, GB1012, https://doi.org/10.1029/2009GB003559, 2010.

Jarníková, T., Dacey, J., Lizotte, M., Levasseur, M., and Tortell, P.: The distribution of methylated sulfur compounds, DMS and DMSP, in Canadian subarctic and Arctic marine waters during summer 2015, Biogeosciences, 15, 2449-2465, https://doi.org/10.5194/bg-15-2449-2018, 2018.

Jiao, C. and Flanner, M. G.: Changing black carbon transport to the Arctic from present day to the end of the 21st century, J. Geophys. Res.-Atmos., 121, 4734-4750, https://doi.org/10.1002/2015JD023964, 2016.

Jodwalis, C. M., Benner, R. L., and Eslinger, D. L.: Modeling of dimethyl sulfide ocean mixing, biological production, and sea-toair flux for high latitudes, J. Geophys. Res.-Atmos., 105, 1438714399, https://doi.org/10.1029/2000JD900023, 2000.

Johnson, M. T., Liss, P. S., Bell, T. G., Lesworth, T. J., Baker, A. R., Hind, A. J., Jickells, T. D., Biswas, K. F., Woodward, E. M. S., and Gibb, S. W.: Field observations of the ocean-atmosphere exchange of ammonia: Fundamental importance of temperature as revealed by a comparison of high and low latitudes, Global Biogeochem. Cy., 22, GB1019, https://doi.org/10.1029/2007GB003039, 2008.

Jouan, C., Pelon, J., Girard, E., Ancellet, G., Blanchet, J. P., and Delanoë, J.: On the relationship between Arctic ice clouds and polluted air masses over the North Slope of Alaska in April 2008, Atmos. Chem. Phys., 14, 1205-1224, https://doi.org/10.5194/acp-14-1205-2014, 2014.

Keegan, K. M., Albert, M. R., McConnell, J. R., and Baker, I.: Climate change and forest fires synergistically drive widespread melt events of the Greenland Ice Sheet, P. Natl. Acad. Sci. USA, 111, 7964-7967, https://doi.org/10.1073/pnas.1405397111, 2014.

Keita, S. A. and Girard, E.: Importance of Chemical Composition of Ice Nuclei on the Formation of Arctic Ice Clouds, Pure Appl. Geophys., 173, 3141-3163, https://doi.org/10.1007/s00024-0161294-z, 2016

Kettle, A. J., Andreae, M. O., Amouroux, D., Andreae, T.W., Bates,T. S., Berresheim, H., Bingemer, H., Boniforti, R., Curran, M. A. J., DiTullio, G. R., Helas, G., Jones, G. B., Keller, M. D., Kiene, R. P., Leck, C., Levasseur, M., Malin, G., Maspero, M., Matrai, P., McTaggart, A. R., Mihapoulos, N., Nguyen, B. C., Novo, A., Putaud, J. P., Rapsomanikis, S., Roberts, G., Schebeske, G., Sharma, S., Simó, R., Staubes, R., Turner, S., and Uher, G.: A global database of sea surface dimethylsulfide (DMS) measurements and a procedure to predict sea surface DMS as a function of latitude, longitude, and month, Global Biogeochem. Cy., 13, 399-444, https://doi.org/10.1029/1999GB900004, 1999.

Khan, M. Y., Giordano, M., Gutierrez, J., Welch, W. A., AsaAwuku, A., Miller, J. W.. and Cocker, D. R.: Benefits of two mitigation strategies for container vessels: cleaner engines and cleaner fuels, Environ. Sci. Technol., 46, 5049-5056, https://doi.org/10.1021/es2043646, 2012.
Kim, M. J., Novak, G. A., Zoerb, M. C., Yang, M., Blomquist, B. W., Huebert, B. J., Cappa, C. D., and Bertram, T. H.: Airsea exchange of volatile organic compounds and the impact on aerosol size distributions, Geophys. Res. Lett., 44, 3887-3896, https://doi.org/10.1002/2017GL072975, 2017.

Kirpes, R. M., Bondy, A. L., Bonanno, D., Moffet, R. C., Wang, B., Laskin, A., Ault, A. P., and Pratt, K. A.: Secondary sulfate is internally mixed with sea spray aerosol and organic aerosol in the winter Arctic, Atmos. Chem. Phys., 18, 3937 3949, https://doi.org/10.5194/acp-18-3937-2018, 2018.

Koch, D. and Del Genio, A. D.: Black carbon semi-direct effects on cloud cover: review and synthesis, Atmos. Chem. Phys., 10, 7685-7696, https://doi.org/10.5194/acp-10-7685-2010, 2010.

Koch, D. and Hansen, J.: Distant origins of Arctic black carbon: A Goddard Institute for Space Studies ModelE experiment, J. Geophys. Res.-Atmos., 110, D04204, https://doi.org/10.1029/2004JD005296, 2005.

Kodros, J. K., Hanna, S. J., Bertram, A. K., Leaitch, W. R., Schulz, H., Herber, A. B., Zanatta, M., Burkart, J., Willis, M. D., Abbatt, J. P. D., and Pierce, J. R.: Size-resolved mixing state of black carbon in the Canadian high Arctic and implications for simulated direct radiative effect, Atmos. Chem. Phys., 18, 11345-11361, https://doi.org/10.5194/acp-18-11345-2018, 2018.

Köllner, F., Schneider, J., Willis, M. D., Klimach, T., Helleis, F., Bozem, H., Kunkel, D., Hoor, P., Burkart, J., Leaitch, W. R., Aliabadi, A. A., Abbatt, J. P. D., Herber, A. B., and Borrmann, S.: Particulate trimethylamine in the summertime Canadian high Arctic lower troposphere, Atmos. Chem. Phys., 17, 1374713766, https://doi.org/10.5194/acp-17-13747-2017, 2017.

Komppula, M., Lihavainen, H., Kerminen, V.-M., Kulmala, M., and Viisanen, Y.: Measurements of cloud droplet activation of aerosol particles at a clean subarctic background site, J. Geophys. Res.Atmos., 110, D06204, https://doi.org/10.1029/2004JD005200, 2005.

Kopp, R. E. and Mauzerall, D. L.: Assessing the climatic benefits of black carbon mitigation, P. Natl. Acad. Sci. USA, 107, 1170311708, https://doi.org/10.1073/pnas.0909605107, 2010.

Korhonen, H., Carslaw, K. S., Spracklen, D. V., Ridley, D. A., and Ström, J.: A global model study of processes controlling aerosol size distributions in the Arctic spring and summer, J. Geophys. Res.-Atmos., 113, D08211, https://doi.org/10.1029/2007JD009114, 2008a.

Korhonen, H., Carslaw, K. S., Spracklen, D. V., Mann, G. W., and Woodhouse, M. T.: Influence of oceanic dimethyl sulfide emissions on cloud condensation nuclei concentrations and seasonality over the remote Southern Hemisphere oceans: A global model study, J. Geophys. Res.-Atmos., 113, D15204, https://doi.org/10.1029/2007JD009718, 2008b.

Laing, J. R., Hopke, P. K., Hopke, E. F., Husain, L., Dutkiewicz, V. A., Paatero, J., and Viisanen, Y.: Long-term trends of biogenic sulfur aerosol and its relationship with sea surface temperature in Arctic Finland, J. Geophys. Res.-Atmos., 118, 11770-11776, https://doi.org/10.1002/2013JD020384, 2013.

Lana, A., Bell, T. G., Simó, R., Vallina, S. M., Ballabrera-Poy, J., Kettle, A. J., Dachs, J., Bopp, L., Saltzman, E. S., Stefels, J., Johnson, J. E., and Liss, P. S.: An updated climatology of surface dimethlysulfide concentrations and emission fluxes in the global ocean, Global Biogeochem. Cy., 25, GB1004, https://doi.org/10.1029/2010GB003850, 2011. 
Law, K. S. and Stohl, A.: Arctic air pollution: origins and impacts, Science, 315, 1537-1540, https://doi.org/10.1126/science.1137695, 2007.

Leaitch, W. R. and Isaac, G. A.: Tropospheric aerosol size distributions from 1982 to 1988 over eastern North America, Atmos. Environ., 25, 601-619, https://doi.org/10.1016/09601686(91)90058-F, 1991.

Leaitch, W. R., Strapp, J. W., Isaac, G. A., and Hudson, J. G.: Cloud droplet nucleation and cloud scavenging of aerosol sulphate in polluted atmospheres, Tellus B, 38, 328-344, https://doi.org/10.3402/tellusb.v38i5.15141, 1986.

Leaitch, W. R., Hoff, R. M., and MacPherson, J. I.: Airborne and lidar measurements of aerosol and cloud particles in the troposphere over Alert Canada in April 1986, J. Atmos. Chem., 9, 187-211, https://doi.org/10.1007/BF00052832, 1989.

Leaitch, W. R., Sharma, S., Huang, L., Toom-Sauntry, D., Chivulescu, A., Macdonald, A. M., von Salzen, K., Pierce, J. R., Betram, A. K., Schroder, J. C., Shantz, N. C., Chang, R., and Norman, A. L.: Dimethyl sulfide control of the clean summertime Arctic aerosol and cloud, Elementa, 1, 000017, https://doi.org/10.12952/journal.elementa.000017, 2013.

Leaitch, W. R., Korolev, A., Aliabadi, A. A., Burkart, J., Willis, M. D., Abbatt, J. P. D., Bozem, H., Hoor, P., Köllner, F., Schneider, J., Herber, A., Konrad, C., and Brauner, R.: Effects of $20-100 \mathrm{~nm}$ particles on liquid clouds in the clean summertime Arctic, Atmos. Chem. Phys., 16, 11107-11124, https://doi.org/10.5194/acp-16-11107-2016, 2016.

Leaitch, W. R., Russell, L. M., Liu, J., Kolonjari, F., Toom, D., Huang, L., Sharma, S., Chivulescu, A., Veber, D., and Zhang, W.: Organic functional groups in the submicron aerosol at $82.5^{\circ} \mathrm{N}$, $62.5^{\circ} \mathrm{W}$ from 2012 to 2014, Atmos. Chem. Phys., 18, 32693287, https://doi.org/10.5194/acp-18-3269-2018, 2018.

Leaitch, W. R., Kodros, J. K., Willis, M., Hanna, S., Schulz, H., Andrews, B., Bozem, H., Burkart, J., Hoor, P., Kolonjari, F., Ogren, J., Sharma, S., Si, M., von Salzen, K., Bertram, A., Herber, A., Abbatt, J. P. D., and Pierce, J. R.: Vertical profiles of light absorption and scattering by Arctic haze particles associated with black- and organic-carbon particle fractions, in preparation, 2019

Leck, C. and Bigg, E. K.: Aerosol production over remote marine areas - A new route, Geophys. Res. Lett., 26, 3577-3580, https://doi.org/10.1029/1999gl010807, 1999.

Leck, C. and Bigg, E. K.: Source and evolution of the marine aerosol - A new perspective, Geophys. Res. Lett., 32, L19803, https://doi.org/10.1029/2005g1023651, 2005

Leck, C. and Bigg, E. K.: A modified aerosol-cloudclimate feedback hypothesis, Environ. Chem., 4, 400-403, https://doi.org/10.1071/EN07061, 2007.

Leck, C. and Persson, C.: The central Arctic Ocean as a source of dimethyl sulfide Seasonal variability in relation to biological activity, Tellus B, 48, 156-177, https://doi.org/10.1034/j.16000889.1996.t01-1-00003.x, 1996.

Le Clainche, Y., Vézina, A., Levasseur, M., Cropp, R. A., Gunson, J. R., Vallina, S. M., Vogt, M., Lancelot, C., Allen, J. I., Archer, S. D., Bopp, L., Deal, C., Elliott, S., Jin, M., Malin, G., Schoemann, V., Simó, R., Six, K. D., and Stefels, J.: A first appraisal of prognostic ocean DMS models and prospects for their use in climate models, Global Biogeochem. Cy., 24, GB3021, https://doi.org/10.1029/2009GB003721, 2010.
Leighton, H.: Influence of arctic haze on the solar radiation budget, Atmos. Environ., 17, 2065-2068, https://doi.org/10.1016/00046981(83)90363-3, 1983.

Levasseur, M.: Impact of Arctic meltdown on the microbial cycling of sulphur, Nat. Geosci., 6, 691-700, https://doi.org/10.1038/ngeo1910, 2013.

Lewis, E. R. and Schwartz, S. E.: Sea salt aerosol production fluxes: estimates and critical analysis, in Sea Salt Aerosol Production: Mechanisms, Methods, Measurements and Models, American Geophysical Union (AGU), 299-344, available at: https://agupubs.onlinelibrary.wiley.com/doi/abs/10. 1002/9781118666050.ch5 (last access: 30 July 2018), 2013.

Libois, Q., Proulx, C., Ivanescu, L., Coursol, L., Pelletier, L. S., Bouzid, Y., Barbero, F., Girard, É., and Blanchet, J.-P.: A microbolometer-based far infrared radiometer to study thin ice clouds in the Arctic, Atmos. Meas. Tech., 9, 1817-1832, https://doi.org/10.5194/amt-9-1817-2016, 2016a.

Libois, Q., Ivanescu, L., Blanchet, J.-P., Schulz, H., Bozem, H., Leaitch, W. R., Burkart, J., Abbatt, J. P. D., Herber, A. B., Aliabadi, A. A., and Girard, É.: Airborne observations of farinfrared upwelling radiance in the Arctic, Atmos. Chem. Phys., 16, 15689-15707, https://doi.org/10.5194/acp-16-15689-2016, 2016 b.

Lizotte, M., Levasseur, M., Galindo, V., Gourdal, M., Gosselin, M., Tremblay, J., Blais, M., and Charrette, J.: Summer phytoplankton dynamics and DMS distribution at two contrasting Arctic ice edges: Barrow Strait and Nares Strait, in preparation, 2019.

Lohmann, U.: A glaciation indirect aerosol effect caused by soot aerosols, Geophys. Res. Lett., 29, 11-1-11-4, https://doi.org/10.1029/2001GL014357, 2002.

Lohmann, U. and Feichter, J.: Global indirect aerosol effects: a review, Atmos. Chem. Phys., 5, 715-737, https://doi.org/10.5194/acp-5-715-2005, 2005.

Lubin, D. and Vogelmann, A. M.: A climatologically significant aerosol longwave indirect effect in the Arctic, Nature, 439, 453456, https://doi.org/10.1038/nature04449, 2006.

Luce, M., Levasseur, M., Scarratt, M. G., Michaud, S., Royer, S.J., Kiene, R., Lovejoy, C., Gosselin, M., Poulin, M., Gratton, Y., and Lizotte, M.: Distribution and microbial metabolism of dimethylsulfoniopropionate and dimethylsulfide during the 2007 Arctic ice minimum, J. Geophys. Res.-Oceans, 116, C00G06, https://doi.org/10.1029/2010JC006914, 2011.

Lutsch, E., Dammers, E., Conway, S., and Strong, K.: Longrange transport of $\mathrm{NH}_{3}, \mathrm{CO}, \mathrm{HCN}$, and $\mathrm{C}_{2} \mathrm{H}_{6}$ from the 2014 Canadian Wildfires, Geophys. Res. Lett., 43, 8286-8297, https://doi.org/10.1002/2016GL070114, 2016.

Ma, P.-L., Rasch, P. J., Wang, H., Zhang, K., Easter, R. C., Tilmes, S., Fast, J. D., Liu, X., Yoon, J.-H., and Lamarque, J.- F.: The role of circulation features on black carbon transport into the Arctic in the Community Atmosphere Model version 5 (CAM5), J. Geophys. Res.-Atmos., 118, 4657-4669, https://doi.org/10.1002/jgrd.50411, 2013.

Macdonald, K. M., Sharma, S., Toom, D., Chivulescu, A., Hanna, S., Bertram, A. K., Platt, A., Elsasser, M., Huang, L., Tarasick, D., Chellman, N., McConnell, J. R., Bozem, H., Kunkel, D., Lei, Y. D., Evans, G. J., and Abbatt, J. P. D.: Observations of atmospheric chemical deposition to high Arctic snow, Atmos. Chem. Phys., 17, 5775-5788, https://doi.org/10.5194/acp17-5775-2017, 2017. 
Macdonald, K. M., Sharma, S., Toom, D., Chivulescu, A., Platt, A., Elsasser, M., Huang, L., Leaitch, R., Chellman, N., McConnell, J. R., Bozem, H., Kunkel, D., Lei, Y. D., Jeong, C.-H., Abbatt, J. P. D., and Evans, G. J.: Temporally delineated sources of major chemical species in high Arctic snow, Atmos. Chem. Phys., 18, 3485-3503, https://doi.org/10.5194/acp-18-3485-2018, 2018.

Mahmood, R., von Salzen, K., Flanner, M., Sand, M., Langner, J., Wang, H., and Huang, L.: Seasonality of global and Arctic black carbon processes in the Arctic Monitoring and Assessment Programme models, J. Geophys. Res.-Atmos., 121, 7100-7116, https://doi.org/10.1002/2016JD024849, 2016.

Mahmood, R., von Salzen, K., Norman, A.-L., Galí, M., and Levasseur, M.: Sensitivity of Arctic sulfate aerosol and clouds to changes in future surface seawater dimethylsulfide concentrations, Atmos. Chem. Phys. Discuss., https://doi.org/10.5194/acp2018-876, in review, 2018.

Marelle, L., Raut, J.-C., Thomas, J. L., Law, K. S., Quennehen, B., Ancellet, G., Pelon, J., Schwarzenboeck, A., and Fast, J. D.: Transport of anthropogenic and biomass burning aerosols from Europe to the Arctic during spring 2008, Atmos. Chem. Phys., 15, 3831-3850, https://doi.org/10.5194/acp15-3831-2015, 2015.

Mason, R. H., Si, M., Chou, C., Irish, V. E., Dickie, R., Elizondo, P., Wong, R., Brintnell, M., Elsasser, M., Lassar, W. M., Pierce, K. M., Leaitch, W. R., MacDonald, A. M., Platt, A., ToomSauntry, D., Sarda-Estève, R., Schiller, C. L., Suski, K. J., Hill, T. C. J., Abbatt, J. P. D., Huffman, J. A., DeMott, P. J., and Bertram, A. K.: Size-resolved measurements of ice-nucleating particles at six locations in North America and one in Europe, Atmos. Chem. Phys., 16, 1637-1651, https://doi.org/10.5194/acp16-1637-2016, 2016.

Massling, A., Nielsen, I. E., Kristensen, D., Christensen, J. H., Sørensen, L. L., Jensen, B., Nguyen, Q. T., Nøjgaard, J. K., Glasius, M., and Skov, H.: Atmospheric black carbon and sulfate concentrations in Northeast Greenland, Atmos. Chem. Phys., 15, 9681-9692, https://doi.org/10.5194/acp-15-9681-2015, 2015.

Matrai, P. A. and Vernet, M.: Dynamics of the vernal bloom in the marginal ice zone of the Barents Sea: Dimethyl sulfide and dimethylsulfoniopropionate budgets, J. Geophys. Res.-Oceans, 102, 22965-22979, https://doi.org/10.1029/96JC03870, 1997.

Matsui, H., Kondo, Y., Moteki, N., Takegawa, N., Sahu, L. K., Zhao, Y., Fuelberg, H. E., Sessions, W. R., Diskin, G., Blake, D. R., Wisthaler, A., and Koike, M.: Seasonal variation of the transport of black carbon aerosol from the Asian continent to the Arctic during the ARCTAS aircraft campaign, J. Geophys. Res.-Atmos., 116, D05202, https://doi.org/10.1029/2010JD015067, 2011.

Mauritsen, T., Sedlar, J., Tjernström, M., Leck, C., Martin, M., Shupe, M., Sjogren, S., Sierau, B., Persson, P. O. G., Brooks, I. M., and Swietlicki, E.: An Arctic CCN-limited cloud-aerosol regime, Atmos. Chem. Phys., 11, 165-173, https://doi.org/10.5194/acp-11-165-2011, 2011.

McConnell, J. R., Edwards, R., Kok, G. L., Flanner, M. G., Zender, C. S., Saltzman, E. S., Banta, J. R., Pasteris, D. R., Carter, M. M., and Kahl, J. D. W.: 20th-century industrial black carbon emissions altered Arctic climate forcing, Science, 317, 1381-1384, https://doi.org/10.1126/science.1144856, 2007.

McCoy, D. T., Burrows, S. M., Wood, R., Grosvenor, D. P., Elliott, S. M., Ma, P.-L., Rasch, P. J., and Hartmann, D. L.: Natural aerosols explain seasonal and spatial patterns of Southern Ocean cloud albedo, Sci. Adv., 1, e1500157, https://doi.org/10.1126/sciadv.1500157, 2015.

McNeill, V. F., Grannas, A. M., Abbatt, J. P. D., Ammann, M., Ariya, P., Bartels-Rausch, T., Domine, F., Donaldson, D. J., Guzman, M. I., Heger, D., Kahan, T. F., Klán, P., Masclin, S., Toubin, C., and Voisin, D.: Organics in environmental ices: sources, chemistry, and impacts, Atmos. Chem. Phys., 12, 9653-9678, https://doi.org/10.5194/acp-12-9653-2012, 2012.

Megaw, W. J. and Flyger, H.: Measurement of the background atmospheric aerosol, J. Aerosol Sci., 4, 179-181, https://doi.org/10.1016/0021-8502(73)90069-4, 1973.

Moran, M., Ménard, S., Talbot, D., Huang, P., Makar, P., Gong, W. F., Landry, H., Gravel, S., Gong, S., Crevier, L.-P., Kallaur, A., and Sassi, M.: Particulate-matter forecasting with GEMMACH15, a new Canadian air-quality forecast model, Springer, NATO Sci. Peace Sec. B, 289-292M, 2010.

Mortenson, E., Hayashida, H., Steiner, N., Monahan, A., Blais, M., Gale, M. A., Galindo, V., Gosselin, M., Hu, X., Lavoie, D., and Mundy, C. J.: A model-based analysis of physical and biological controls on ice algal and pelagic primary production in Resolute Passage, Elem. Sci. Anth., 5, 39, https://doi.org/10.1525/elementa.229, 2017.

Mortenson, E., Steiner, N., Monahan, A. H., Miller, L. A., Geilfus, N. X., and Brown, K.: A model-based analysis of physical and biogeochemical controls on carbon exchange in the upper water column, sea ice, and atmosphere in a seasonally icecovered Arctic strait, J. Geophys. Res.-Oceans, 123, 7529-7549, https://doi.org/10.1029/2018JC014376, 2018.

Motard-Côté, J., Levasseur, M., Scarratt, M. G., Michaud, S., Gratton, Y., Rivkin, R. B., Keats, K., Gosselin, M., Tremblay, J.-É., Kiene, R. P., and Lovejoy, C.: Distribution and metabolism of dimethylsulfoniopropionate (DMSP) and phylogenetic affiliation of DMSP-assimilating bacteria in northern Baffin Bay/Lancaster Sound, J. Geophys. Res.-Oceans, 117, C088G11, https://doi.org/10.1029/2011JC007330, 2012.

Mundy, C. J., Gosselin, M., Ehn, J., Gratton, Y., Rossnagel, A., Barber, D. G., Martin, J., Tremblay, J.-É., Palmer, M., Arrigo, K. R., Darnis, G., Fortier, L., Else, B., and Papakyriakou, T.: Contribution of under-ice primary production to an ice-edge upwelling phytoplankton bloom in the Canadian Beaufort Sea, Geophys. Res. Lett., 36, L17601, https://doi.org/10.1029/2009GL038837, 2009.

Mungall, E. L., Croft, B., Lizotte, M., Thomas, J. L., Murphy, J. G., Levasseur, M., Martin, R. V., Wentzell, J. J. B., Liggio, J., and Abbatt, J. P. D.: Dimethyl sulfide in the summertime Arctic atmosphere: measurements and source sensitivity simulations, Atmos. Chem. Phys., 16, 6665-6680, https://doi.org/10.5194/acp16-6665-2016, 2016.

Mungall, E. L., Abbatt, J. P. D., Wentzell, J. J. B., Lee, A. K. Y., Thomas, J. L., Blais, M., Gosselin, M., Miller, L. A., Papakyriakou, T., Willis, M. D., and Liggio, J.: Microlayer source of oxygenated volatile organic compounds in the summertime marine Arctic boundary layer, P. Natl. Acad. Sci. USA, 114, 6203, https://doi.org/10.1073/pnas.1620571114, 2017.

Murphy, J. G., Moravek, A., Wentworth, G. R., Croft, B., Martin, R. V., Pierce, J., Mungall, E. L., and Abbatt, J. P. D.: Observational constraints on the atmospheric ammonia budget in the Canadian Arctic Archipelago, in preparation, 2019. 
Murray, B. J., O'Sullivan, D., Atkinson, J. D., and Webb, M. E.: Ice nucleation by particles immersed in supercooled cloud droplets, Chem. Soc. Rev., 41, 6519-6554, https://doi.org/10.1039/C2CS35200A, 2012.

Najafi, M. R., Zwiers, F. W., and Gillett, N. P.: Attribution of Arctic temperature change to greenhouse-gas and aerosol influences, Nat. Clim. Change, 5, 246-249, https://doi.org/10.1038/nclimate2524, 2015.

Namazi, M., von Salzen, K., and Cole, J. N. S.: Simulation of black carbon in snow and its climate impact in the Canadian Global Climate Model, Atmos. Chem. Phys., 15, 10887-10904, https://doi.org/10.5194/acp-15-10887-2015, 2015.

Navarro, J. C. A., Varma, V., Riipinen, I., Seland, Ø., Kirkevåg, A., Struthers, H., Iversen, T., Hansson, H.-C., and Ekman, A. M. L.: Amplification of Arctic warming by past air pollution reductions in Europe, Nat. Geosci., 9, 277-281, https://doi.org/10.1038/ngeo2673, 2016.

O’Neill, N. T., Baibakov, K., Hesaraki, S., Ivanescu, L., Martin, R. V., Perro, C., Chaubey, J. P., Herber, A., and Duck, T. J.: Temporal and spectral cloud screening of polar winter aerosol optical depth (AOD): impact of homogeneous and inhomogeneous clouds and crystal layers on climatological-scale AODs, Atmos. Chem. Phys., 16, 12753-12765, https://doi.org/10.5194/acp-1612753-2016, 2016.

Orellana, M. V., Matrai, P. A., Leck, C., Rauschenberg, C. D., Lee, A. M., and Coz, E.: Marine microgels as a source of cloud condensation nuclei in the high Arctic, P. Natl. Acad. Sci. USA, 108, 13612-13617, https://doi.org/10.1073/pnas.1102457108, 2011.

Park, K.-T., Lee, K., Yoon, Y.-J., Lee, H.-W., Kim, H.C., Lee, B.-Y., Hermansen, O., Kim, T.-W., and Holmén, K.: Linking atmospheric dimethyl sulfide and the Arctic Ocean spring bloom, Geophys. Res. Lett., 40, 155-160, https://doi.org/10.1029/2012GL054560, 2013.

Park, K.-T., Jang, S., Lee, K., Yoon, Y. J., Kim, M.-S., Park, K., Cho, H.-J., Kang, J.-H., Udisti, R., Lee, B.-Y., and Shin, K.-H.: Observational evidence for the formation of DMS-derived aerosols during Arctic phytoplankton blooms, Atmos. Chem. Phys., 17, 9665-9675, https://doi.org/10.5194/acp-17-9665-2017, 2017.

Park, K.-T., Lee, K., Kim, T.-W., Yoon, Y. J., Jang, E.H., Jang, S., Lee, B.-Y., and Hermansen, O.: Atmospheric DMS in the Arctic Ocean and Its Relation to Phytoplankton Biomass, Global Biogeochem. Cy., 32, 351-359, https://doi.org/10.1002/2017GB005805, 2018.

Pereira, R., Schneider-Zapp, K., and Upstill-Goddard, R. C.: Surfactant control of gas transfer velocity along an offshore coastal transect: results from a laboratory gas exchange tank, Biogeosciences, 13, 3981-3989, https://doi.org/10.5194/bg-13-39812016, 2016.

Perrette, M., Yool, A., Quartly, G. D., and Popova, E. E.: Nearubiquity of ice-edge blooms in the Arctic, Biogeosciences, 8, 515-524, https://doi.org/10.5194/bg-8-515-2011, 2011.

Petzold, A., Weingartner, E., Hasselbach, J., Lauer, P., Kurok, C., and Fleischer, F.: Physical properties, chemical composition, and cloud forming potential for particulate emissions from a marine diesel engine at various load conditions, Environ. Sci. Technol., 44, 3800-3805, https://doi.org/10.1021/es903681z, 2010.

Petzold, A., Lauer, P., Fritsche, U., Hasselbach, J., Lichtenstern, M., Schlager, H., and Fleischer, F.: Operation of marine diesel engines on biogenic fuels: modification of emissions and result- ing climate effects, Environ. Sci. Technol., 45, 10394-10400, https://doi.org/10.1021/es2021439, 2011.

Pizzolato, L., Howell, S. E. L., Derksen, C., Dawson, J., and Copland, L.: Changing sea ice conditions and marine transportation activity in Canadian Arctic waters between 1990 and 2012, Climatic Change, 123, 161-173, https://doi.org/10.1007/s10584013-1038-3, 2014.

Pueschel, R. F. and Kinne, S. A.: Physical and radiative properties of Arctic atmospheric aerosols, Sci. Total Environ., 160-161, 811824, https://doi.org/10.1016/0048-9697(95)04414-V, 1995.

Qi, L., Li, Q., Henze, D. K., Tseng, H.-L., and He, C.: Sources of springtime surface black carbon in the Arctic: an adjoint analysis for April 2008, Atmos. Chem. Phys., 17, 9697-9716, https://doi.org/10.5194/acp-17-9697-2017, 2017.

Quinn, P. K. and Bates, T. S.: The case against climate regulation via oceanic phytoplankton sulphur emissions, Nature, 480, 5156, https://doi.org/10.1038/nature10580, 2011.

Quinn, P. K., Shaw, G., Andrews, E., Dutton, E. G., Ruoho-Airola, T., and Gong, S. L.: Arctic haze: current trends and knowledge gaps, Tellus B, 59, 99-114, https://doi.org/10.1111/j.16000889.2006.00238.x, 2006.

Quinn, P. K., Bates, T. S., Baum, E., Doubleday, N., Fiore, A. M., Flanner, M., Fridlind, A., Garrett, T. J., Koch, D., Menon, S., Shindell, D., Stohl, A., and Warren, S. G.: Shortlived pollutants in the Arctic: their climate impact and possible mitigation strategies, Atmos. Chem. Phys., 8, 1723-1735, https://doi.org/10.5194/acp-8-1723-2008, 2008.

Quinn, P. K., Bates, T. S., Schulz, K., and Shaw, G. E.: Decadal trends in aerosol chemical composition at Barrow, Alaska: 1976-2008, Atmos. Chem. Phys., 9, 8883-8888, https://doi.org/10.5194/acp-9-8883-2009, 2009.

Radke, L. F., Lyons, J. H., Hegg, D. A., Hobbs, P. V., and Bailey, I. H.: Airborne observations of Arctic aerosols. I: Characteristics of Arctic haze, Geophys. Res. Lett., 11, 393-396, https://doi.org/10.1029/GL011i005p00393, 1984.

Rahn, K. A. and Heidam, N. Z.: Progress in arctic air chemistry, 1977-1980: A comparison of the first and second symposia, Atmos. Environ., 15, 1345-1348, https://doi.org/10.1016/00046981(81)90339-5, 1981.

Rempillo, O., Seguin, A. M., Norman, A.-L., Scarratt, M., Michaud, S., Chang, R., Sjostedt, S., Abbatt, J., Else, B., Papakyriakou, T., Sharma, S., Grasby, S., and Levasseur, M.: Dimethyl sulfide air-sea fluxes and biogenic sulfur as a source of new aerosols in the Arctic fall, J. Geophys. Res.-Atmos., 116, D00S04, https://doi.org/10.1029/2011JD016336, 2011.

Ribas-Ribas, M., Hamizah Mustaffa, N. I., Rahlff, J., Stolle, C., and Wurl, O.: Sea Surface Scanner (S3): A Catamaran for HighResolution Measurements of Biogeochemical Properties of the Sea Surface Microlayer, J. Atmos. Ocean. Tech., 34, 1433-1448, https://doi.org/10.1175/JTECH-D-17-0017.1, 2017.

Rinaldi, M., Decesari, S., Finessi, E., Giulianelli, L., Carbone, C., Fuzzi, S., O’Dowd, C. D., Ceburnis, D., and Facchini, M. C.: Primary and Secondary Organic Marine Aerosol and Oceanic Biological Activity: Recent Results and New Perspectives for Future Studies, Adv. Meteorol., 2010, 310682, https://doi.org/10.1155/2010/310682, 2010.

Rogers, D. C., DeMott, P. J., Kreidenweis, S. M., and Chen, Y.: Measurements of ice nucleating aerosols dur- 
ing SUCCESS, Geophys. Res. Lett., 25, 1383-1386, https://doi.org/10.1029/97GL03478, 1998.

Roiger, A., Schlager, H., Schäfler, A., Huntrieser, H., Scheibe, M., Aufmhoff, H., Cooper, O. R., Sodemann, H., Stohl, A., Burkhart, J., Lazzara, M., Schiller, C., Law, K. S., and Arnold, F.: Insitu observation of Asian pollution transported into the Arctic lowermost stratosphere, Atmos. Chem. Phys., 11, 10975-10994, https://doi.org/10.5194/acp-11-10975-2011, 2011.

Rösel, A., Kaleschke, L., and Birnbaum, G.: Melt ponds on Arctic sea ice determined from MODIS satellite data using an artificial neural network, The Cryosphere, 6, 431-446, https://doi.org/10.5194/tc-6-431-2012, 2012.

Rossignol, S., Tinel, L., Bianco, A., Passananti, M., Brigante, M., Donaldson, D. J., and George, C.: Atmospheric photochemistry at a fatty acid-coated air-water interface, Science, 353, 699-702, https://doi.org/10.1126/science.aaf3617, 2016.

Sand, M., Berntsen, T. K., Kay, J. E., Lamarque, J. F., Seland, $\varnothing$., and Kirkevåg, A.: The Arctic response to remote and local forcing of black carbon, Atmos. Chem. Phys., 13, 211-224, https://doi.org/10.5194/acp-13-211-2013, 2013.

Sassen, K., DeMott, P. J., Prospero, J. M., and Poellot, M. R.: Saharan dust storms and indirect aerosol effects on clouds: CRYSTAL-FACE results, Geophys. Res. Lett., 30, 1633, https://doi.org/10.1029/2003GL017371, 2003.

Schmale, J., Schneider, J., Ancellet, G., Quennehen, B., Stohl, A., Sodemann, H., Burkhart, J. F., Hamburger, T., Arnold, S. R., Schwarzenboeck, A., Borrmann, S., and Law, K. S.: Source identification and airborne chemical characterisation of aerosol pollution from long-range transport over Greenland during POLARCAT summer campaign 2008, Atmos. Chem. Phys., 11, 1009710123, https://doi.org/10.5194/acp-11-10097-2011, 2011.

Schmeisser, L., Backman, J., Ogren, J. A., Andrews, E., Asmi, E., Starkweather, S., Uttal, T., Fiebig, M., Sharma, S., Eleftheriadis, K., Vratolis, S., Bergin, M., Tunved, P., and Jefferson, A.: Seasonality of aerosol optical properties in the Arctic, Atmos. Chem. Phys., 18, 11599-11622, https://doi.org/10.5194/acp-18-115992018, 2018.

Schnell, R. C.: Ice nuclei in seawater, fog water and marine air off the coast of Nova Scotia: summer 1975, J. Atmos. Sci., 34, 1299-1305, https://doi.org/10.1175/15200469(1977)034<1299:INISFW>2.0.CO;2, 1977.

Schnell, R. C. and Raatz, W. E.: Vertical and horizontal characteristics of Arctic haze during AGASP: Alaskan Arctic, Geophys. Res. Lett., 11, 369-372, https://doi.org/10.1029/GL011i005p00369, 1984.

Schnell, R. C. and Vali, G.: Freezing nuclei in marine waters, Tellus, 27, 321-323, https://doi.org/10.3402/tellusa.v27i3.9911, 1975.

Schnell, R. C. and Vali, G.: Biogenic Ice Nuclei: Part I. Terrestrial and Marine Sources, J. Atmos. Sci., 33, 1554-1564, https://doi.org/10.1175/15200469(1976)033<1554:BINPIT>2.0.CO;2, 1976.

Schulz, H., Zanatta, M., Bozem, H., Leaitch, W. R., Herber, A. B., Burkart, J., Willis, M. D., Kunkel, D., Hoor, P. M., Abbatt, J. P. D., and Gerdes, R.: High Arctic aircraft measurements characterising black carbon vertical variability in spring and summer, Atmos. Chem. Phys., 19, 2361-2384, https://doi.org/10.5194/acp19-2361-2019, 2019.
Serreze, M. C. and Barry, R. G.: Processes and impacts of Arctic amplification: A research synthesis, Global Planet. Change, 77, 85-96, https://doi.org/10.1016/j.gloplacha.2011.03.004, 2011.

Sharma, S., Lavoué, D., Cachier, H., Barrie, L. A., and Gong, S. L.: Long-term trends of the black carbon concentrations in the Canadian Arctic, J. Geophys. Res.-Atmos., 109, D15203, https://doi.org/10.1029/2003JD004331, 2004.

Sharma, S., Andrews, E., Barrie, L. A., Ogren, J. A., and Lavoué, D.: Variations and sources of the equivalent black carbon in the high Arctic revealed by long-term observations at Alert and Barrow: 1989-2003, J. Geophys. Res.-Atmos., 111, D14208, https://doi.org/10.1029/2005JD006581, 2006.

Sharma, S., Chan, E., Ishizawa, M., Toom-Sauntry, D., Gong, S. L., Li, S. M., Tarasick, D. W., Leaitch, W. R., Norman, A., Quinn, P. K., Bates, T. S., Levasseur, M., Barrie, L. A., and Maenhaut, W.: Influence of transport and ocean ice extent on biogenic aerosol sulfur in the Arctic atmosphere, J. Geophys. Res.-Atmos., 117, D12209, https://doi.org/10.1029/2011JD017074, 2012.

Sharma, S., Ishizawa, M., Chan, D., Lavoué, D., Andrews, E., Eleftheriadis, K., and Maksyutov, S.: 16-year simulation of Arctic black carbon: Transport, source contribution, and sensitivity analysis on deposition, J. Geophys. Res.-Atmos., 118, 943-964, https://doi.org/10.1029/2012JD017774, 2013.

Sharma, S., Leaitch, W. R., Huang, L., Veber, D., Kolonjari, F., Zhang, W., Hanna, S. J., Bertram, A. K., and Ogren, J. A.: An evaluation of three methods for measuring black carbon in Alert, Canada, Atmos. Chem. Phys., 17, 15225-15243, https://doi.org/10.5194/acp-17-15225-2017, 2017.

Shaw, G. E.: Evidence for a central Eurasian source area of Arctic haze in Alaska, Nature, 299, 815-818, https://doi.org/10.1038/299815a0, 1982.

Shaw, P. M., Russell, L. M., Jefferson, A., and Quinn, P. K.: Arctic organic aerosol measurements show particles from mixed combustion in spring haze and from frost flowers in winter, Geophys. Res. Lett., 37, L10803, https://doi.org/10.1029/2010GL042831, 2010.

Shindell, D. and Faluvegi, G.: Climate response to regional radiative forcing during the twentieth century, Nat. Geosci., 2, 294-300, https://doi.org/10.1038/ngeo473, 2009.

Shindell, D. T., Chin, M., Dentener, F., Doherty, R. M., Faluvegi, G., Fiore, A. M., Hess, P., Koch, D. M., MacKenzie, I. A., Sanderson, M. G., Schultz, M. G., Schulz, M., Stevenson, D. S., Teich, H., Textor, C., Wild, O., Bergmann, D. J., Bey, I., Bian, H., Cuvelier, C., Duncan, B. N., Folberth, G., Horowitz, L. W., Jonson, J., Kaminski, J. W., Marmer, E., Park, R., Pringle, K. J., Schroeder, S., Szopa, S., Takemura, T., Zeng, G., Keating, T. J., and Zuber, A.: A multi-model assessment of pollution transport to the Arctic, Atmos. Chem. Phys., 8, 5353-5372, https://doi.org/10.5194/acp-8-5353-2008, 2008.

Si, M., Evoy, E., Yun, J., Xi, Y., Hanna, S., Chivulescu, A., Rawlings, K., Platt, A., Kunkel, D., Hoor, P., Sharma, S., Leaitch, W. R., and Bertram, A. K.: Concentrations, composition, and sources of ice-nucleating particles in the Canadian High Arctic during spring 2016, Atmos. Chem. Phys. Discuss., https://doi.org/10.5194/acp-2018-950, in review, 2018.

Simó, R.: Production of atmospheric sulfur by oceanic plankton: biogeochemical, ecological and evolutionary links, Trends Ecol. Evol., 16, 287-294, https://doi.org/10.1016/S01695347(01)02152-8, 2001. 
Sinha, P. R., Kondo, Y., Koike, M., Ogren, J. A., Jefferson, A., Barrett, T. E., Sheesley, R. J., Ohata, S., Moteki, N., Coe, H., Liu, D., Irwin, M., Tunved, P., Quinn, P. K., and Zhao, Y.: Evaluation of ground-based black carbon measurements by filter-based photometers at two Arctic sites, J. Geophys. Res.-Atmos., 122, 3544-3572, https://doi.org/10.1002/2016JD025843, 2017.

Sirois, A. and Barrie, L. A.: Arctic lower tropospheric aerosol trends and composition at Alert, Canada: 19801995, J. Geophys. Res.-Atmos., 104, 11599-11618, https://doi.org/10.1029/1999JD900077, 1999.

Staebler, R. M., den Hartog, G., Bernd, G., and Thorsten, D.: Aerosol size distributions in Arctic haze during the Polar Sunrise Experiment 1992, J. Geophys. Res.-Atmos., 99, 25429-25437, https://doi.org/10.1029/94JD00520, 1994.

Stefels, J., Steinke, M., Turner, S., Malin, G., and Belviso, S.: Environmental constraints on the production and removal of the climatically active gas dimethylsulphide (DMS) and implications for ecosystem modelling, Biogeochemistry, 83, 245-275, https://doi.org/10.1007/s10533-007-9091-5, 2007.

Steiner, N., Azetsu-Scott, K., Hamilton, J., Hedges, K., Hu, X., Janjua, M. Y., Lavoie, D., Loder, J., Melling, H., Merzouk, A., Perrie, W., Peterson, I., Scarratt, M., Sou, T., and Tallmann, R.: Observed trends and climate projections affecting marine ecosystems in the Canadian Arctic, Environ. Rev., 23, 191-239, https://doi.org/10.1139/er-2014-0066, 2015.

Stohl, A.: Characteristics of atmospheric transport into the Arctic troposphere, J. Geophys. Res.-Atmos., 111, D11306, https://doi.org/10.1029/2005JD006888, 2006.

Stohl, A., Forster, C., Frank, A., Seibert, P., and Wotawa, G.: Technical note: The Lagrangian particle dispersion model FLEXPART version 6.2, Atmos. Chem. Phys., 5, 2461-2474, https://doi.org/10.5194/acp-5-2461-2005, 2005.

Stohl, A., Law, K., Bottenheim, J. W., Monks, P., and Quinn, P. (Eds.): POLARCAT (Polar Study using Aircraft, Remote Sensing, Surface Measurements and Models, of Climate, Chemistry, Aerosols, and Transport), Atmos. Chem. Phys., https://www. atmos-chem-phys.net/special_issue182.html, 2009.

Tesdal, J.-E., R. Christian, J., H. Monahan, A., and von Salzen, K.: Evaluation of diverse approaches for estimating sea-surface DMS concentration and air-sea exchange at global scale, Environ. Chem., 13, 390-412, https://doi.org/10.1071/EN14255, 2015.

Tesdal, J.-E., Christian, J. R., Monahan, A. H., and von Salzen, K.: Sensitivity of modelled sulfate aerosol and its radiative effect on climate to ocean DMS concentration and air-sea flux, Atmos. Chem. Phys., 16, 10847-10864, https://doi.org/10.5194/acp-1610847-2016, 2016.

Valero, F. P. J., Ackerman, T. P., and Gore, W. J. Y.: The absorption of solar radiation by the Arctic atmosphere during the haze season and its effects on the radiation balance, Geophys. Res. Lett., 11, 465-468, https://doi.org/10.1029/GL011i005p00465, 1984.

Vali, G., DeMott, P. J., Möhler, O., and Whale, T. F.: Technical Note: A proposal for ice nucleation terminology, Atmos. Chem. Phys., 15, 10263-10270, https://doi.org/10.5194/acp-15-102632015, 2015.

Vergara-Temprado, J., Murray, B. J., Wilson, T. W., O’Sullivan, D., Browse, J., Pringle, K. J., Ardon-Dryer, K., Bertram, A. K., Burrows, S. M., Ceburnis, D., DeMott, P. J., Mason, R. H., O’Dowd, C. D., Rinaldi, M., and Carslaw, K. S.: Contribution of feldspar and marine organic aerosols to global ice nucleating particle concentrations, Atmos. Chem. Phys., 17, 3637-3658, https://doi.org/10.5194/acp-17-3637-2017, 2017.

von Salzen, K., Scinocca, J. F., McFarlane, N. A., Li, J., Cole, J. N. S., Plummer, D., Verseghy, D., Reader, M. C., Ma, X., Lazare, M., and Solheim, L.: The Canadian Fourth Generation Atmospheric Global Climate Model (CanAM4). Part I: Representation of Physical Processes, Atmos.-Ocean, 51, 104-125, https://doi.org/10.1080/07055900.2012.755610, 2013

Wagner, R., Kaufmann, J., Möhler, O., Saathoff, H., Schnaiter, M., Ullrich, R., and Leisner, T.: Heterogeneous ice nucleation ability of NACL and sea salt aerosol particles at cirrus temperatures, J. Geophys. Res.-Atmos., 123, 2841-2860, https://doi.org/10.1002/2017JD027864, 2018.

Wang, H., Easter, R. C., Rasch, P. J., Wang, M., Liu, X., Ghan, S. J., Qian, Y., Yoon, J.-H., Ma, P.-L., and Vinoj, V.: Sensitivity of remote aerosol distributions to representation of cloud-aerosol interactions in a global climate model, Geosci. Model Dev., 6, 765-782, https://doi.org/10.5194/gmd-6-765-2013, 2013.

Wang, H., Rasch, P. J., Easter, R. C., Singh, B., Zhang, R., Ma, P.-L., Qian, Y., Ghan, S. J., and Beagley, N.: Using an explicit emission tagging method in global modeling of source-receptor relationships for black carbon in the Arctic: variations, sources, and transport pathways, J. Geophys. Res.-Atmos., 119, 1288812909, https://doi.org/10.1002/2014JD022297, 2014.

Wang, X., Doherty, S. J., and Huang, J.: Black carbon and other light-absorbing impurities in snow across Northern China, J. Geophys. Res.-Atmos., 118, 1471-1492, https://doi.org/10.1029/2012JD018291, 2013.

Weimerskirch, H., Bouard, F. L., Ryan, P. G., and Bost, C. A.: Massive decline of the world's largest king penguin colony at Ile aux Cochons, Crozet, Antarct. Sci., 30, 236-242, https://doi.org/10.1017/S0954102018000226, 2018.

Wentworth, G. R., Murphy, J. G., Croft, B., Martin, R. V., Pierce, J. R., Côté, J.-S., Courchesne, I., Tremblay, J.-É., Gagnon, J., Thomas, J. L., Sharma, S., Toom-Sauntry, D., Chivulescu, A., Levasseur, M., and Abbatt, J. P. D.: Ammonia in the summertime Arctic marine boundary layer: sources, sinks, and implications, Atmos. Chem. Phys., 16, 1937-1953, https://doi.org/10.5194/acp-16-1937-2016, 2016.

Willis, M. D., Burkart, J., Thomas, J. L., Köllner, F., Schneider, J., Bozem, H., Hoor, P. M., Aliabadi, A. A., Schulz, H., Herber, A. B., Leaitch, W. R., and Abbatt, J. P. D.: Growth of nucleation mode particles in the summertime Arctic: a case study, Atmos. Chem. Phys., 16, 7663-7679, https://doi.org/10.5194/acp16-7663-2016, 2016.

Willis, M. D., Köllner, F., Burkart, J., Bozem, H., Thomas, J. L., Schneider, J., Aliabadi, A. A., Hoor, P. M., Schulz, H., Herber, A. B., Leaitch, W. R., and Abbatt, J. P. D.: Evidence for marine biogenic influence on summertime Arctic aerosol, Geophys. Res. Lett., 44, 6460-6470, https://doi.org/10.1002/2017GL073359, 2017.

Willis, M. D., Leaitch, W. R., and Abbatt, J. P. D.: Processes controlling the composition and abundance of Arctic aerosol, Rev. Geophys., 56, 621-671, https://doi.org/10.1029/2018RG000602, 2018.

Willis, M. D., Bozem, H., Kunkel, D., Lee, A. K. Y., Schulz, H., Burkart, J., Aliabadi, A. A., Herber, A. B., Leaitch, W. R., and Abbatt, J. P. D.: Aircraft-based measurements of High Arctic 
springtime aerosol show evidence for vertically varying sources, transport and composition, Atmos. Chem. Phys., 19, 57-76, https://doi.org/10.5194/acp-19-57-2019, 2019.

Wilson, T. W., Ladino, L. A., Alpert, P. A., Breckels, M. N., Brooks, I. M., Browse, J., Burrows, S. M., Carslaw, K. S., Huffman, J. A., Judd, C., Kilthau, W. P., Mason, R. H., McFiggans, G., Miller, L. A., Najera, J. J., Polishchuk, E., Rae, S., Schiller, C. L., Si, M., Temprado, J. V., Whale, T. F., Wong, J. P. S., Wurl, O., Yakobi-Hancock, J. D., Abbatt, J. P. D., Aller, J. Y., Bertram, A. K., Knopf, D. A., and Murray, B. J.: A marine biogenic source of atmospheric ice-nucleating particles, Nature, 525, 234-238, https://doi.org/10.1038/nature14986, 2015.

Winther, M., Christensen, J. H., Plejdrup, M. S., Ravn, E. S., Eriksson, O. F., and Kristensen, H. O.: Emission inventories for ships in the arctic based on satellite sampled AIS data, Atmos. Environ., 91, 1-14, https://doi.org/10.1016/j.atmosenv.2014.03.006, 2014.

Xu, J.-W., Martin, R. V., Morrow, A., Sharma, S., Huang, L., Leaitch, W. R., Burkart, J., Schulz, H., Zanatta, M., Willis, M. D., Henze, D. K., Lee, C. J., Herber, A. B., and Abbatt, J. P. D.: Source attribution of Arctic black carbon constrained by aircraft and surface measurements, Atmos. Chem. Phys., 17, 1197111989, https://doi.org/10.5194/acp-17-11971-2017, 2017.
Yamamoto-Kawai, M., McLaughlin, F. A., Carmack, E. C., Nishino, S., and Shimada, K.: Aragonite undersaturation in the Arctic Ocean: effects of ocean acidification and sea ice melt, Science, 326, 1098-1100, https://doi.org/10.1126/science.1174190, 2009.

Zamora, L. M., Kahn, R. A., Eckhardt, S., McComiskey, A. Sawamura, P., Moore, R., and Stohl, A.: Aerosol indirect effects on the nighttime Arctic Ocean surface from thin, predominantly liquid clouds, Atmos. Chem. Phys., 17, 7311-7332, https://doi.org/10.5194/acp-17-7311-2017, 2017.

Zhao, C. and Garrett, T. J.: Effects of Arctic haze on surface cloud radiative forcing, Geophys. Res. Lett., 42, 557-564, https://doi.org/10.1002/2014GL062015, 2015.

Zhou, S., Gonzalez, L., Leithead, A., Finewax, Z., Thalman, R., Vlasenko, A., Vagle, S., Miller, L. A., Li, S.-M., Bureekul, S., Furutani, H., Uematsu, M., Volkamer, R., and Abbatt, J.: Formation of gas-phase carbonyls from heterogeneous oxidation of polyunsaturated fatty acids at the air-water interface and of the sea surface microlayer, Atmos. Chem. Phys., 14, 1371-1384, https://doi.org/10.5194/acp-14-1371-2014, 2014. 